\title{
"EL ESTUDIO DE LAS MARCAS DE AGUA DEL PAPEL COMO MATERIAL PARA DETERMINAR LA DATACIÓN Y PROCEDENCIA DE LAS FUENTES HISTÓRICO-MUSICALES, Y SU GRADO DE FIABILIDAD.
}

\author{
(UNA PRIMERA APROXIMACIÓN, A PARTIR DE LOS MANUSCRITOS \\ DE LA PRIMERA MITAD DEL SIGLO XVII DEL ARCHIVO DE MÚSICA \\ DE LAS CATEDRALES DE ZARAGOZA)"**
}

\author{
Antonio EzQuERro EsTEBAN \\ Departamento de Musicología, CSIC, Barcelona
}

\begin{abstract}
The analysis of watermarks (considered the hallmark of the manufacturer) as a tool for dating musical documents, and even for investigating their possible places of provenance, is a field that up till now has warranted little attention on the part of the musicologists in our country. We have had to rely on the studies of historians, mostly concerned with the period of the Middle Ages, on sources from other countries or on investigations overly parochial. On the other hand, basic reference bibliography is outdated and affords few tangible indications to the musicologist interested in dating the sources of his study. Taking as a case in point the musical sources from the first half of the seventeenth century originating from the Music Archives of the Cathedrals of Zaragoza, this study will endeavour to furnish a starting point for future studies, while at the same time awakening scholars to the need to compile as many watermarks as they possibly can, with a view to assembling a good collection of available materials "to compare", thereby creating a foundation for future studies of historical Musicology in the Hispanic field.
\end{abstract}

\section{Resumen}

El estudio de las marcas de agua del papel (consideradas como marca del fabricante) como herramienta para datar documentos musicales, e incluso para investigar sus posibles procedencias, es un terreno que hasta la fecha ha merecido escasa atención (en cualquier caso, menos de la que mereciera) por parte de los musicólogos en nuestro país. Dependemos de trabajos de historiadores, en la mayoría de las ocasiones centrados en el período medieval, en fuentes de otros países, o en estudios excesivamente localizados. Por otro lado, la bibliografía de referencia básica es antigua y proporciona pocas pistas concretas al musicólogo interesado en datar las fuentes de su estudio. A partir de un caso concreto, las fuentes musicales de la primera mitad del siglo XVII del Archivo de Música de las Catedrales de Zaragoza, este trabajo pretende plantear puntos de arranque para futuros trabajos, al tiempo que concienciar a los profesionales de la necesidad de recoger cuantas más marcas de agua, mejor, con vistas a contar con una buena colección de materiales entre los que poder "comparar", y hacer así de esta herramienta (todavía hoy, y para nuestra disciplina, no excesivamente "fiable", —únicamente por lo joven e inexplorada-), un apoyo básico para los estudios de la Musicología histórica del ámbito hispano.

* Este artículo corresponde al subcapítulo "Las marcas de agua”, de mi tesis doctoral, La música vocal en Aragón en el segundo tercio del siglo XVII. (Tipologías, técnicas de composición, estilo y relación música-texto en las composiciones de las 
En Musicología histórica, como en otras disciplinas del ámbito de las ciencias humanas, la validez de un estudio suele estar condicionada por factores tales como la fiabilidad y la representatividad de la información (es decir, de las fuentes que vamos a utilizar para la confección del trabajo), el método de tratamiento de los datos, y los criterios de interpretación que se utilicen $^{1}$. Las fuentes conservadas en el Archivo de Música de las Catedrales de Zaragoza, el principal para todo Aragón durante el siglo XVII, constituyen la base sobre la que se asienta este trabajo. Será por tanto conveniente ver si esta información es fiable y representativa, determinar el método de tratamiento de los datos que haya proporcionado y, finalmente, fijar los criterios de interpretación que nos permitan llegar a conclusiones válidas.

La valoración del grado de fiabilidad de estas fuentes, parece lógico que debería encaminarse al menos en dos direcciones básicas: tanto en el sentido de su autoría (apartado que mo abordaré en este trabajo), como en el de la datación. Un procedimiento muy controvertido, pero útil en cuanto permite ampliar considerablemente nuestras informaciones con vistas a la datación, es la utilización de las denominadas marcas de agua del papel, también conocidas como filigranas $^{2}$. Cualquier documento escrito lleva, por su letra, construcción del texto, redacción, giros, abreviaturas, etc., elementos que pueden permitir dar una fecha aproximada de cuándo se escribió. Si a todo ello le añadimos además las peculiares características de la grafía musical, la relativa complejidad para datar un documento, en este caso musical, se reducirá considerablemente. Pero además, el soporte, el papel, puede servir también para apoyar su datación ${ }^{3}$.

En España, este procedimiento está prácticamente inexplotado, más aún si nos ceñimos al terreno de la investigación histórico-musical ${ }^{4}$. Hasta la fecha, que conozca, tan sólo han aparecido dos trabajos que abordan el tema desde esta perspectiva, aparte de un único ejemplo — poco significativo, prácticamente despreciable para nuestros propósitos - aparecido en el prólogo a la edición facsímil de los Fragmentos Músicos de Pablo Nassarre 5 . Aparte de algunos estudios de doctoran-

catedrales de Zaragoza), Universitat Autònoma de Barcelona, 1997. Opiniones de algunos colegas y amigos han aconsejado publicar ahora este trabajo, refundido y algo actualizado, con vistas a establecer un "status quaestionis" del asunto, que acaso pueda servir como punto de partida para futuras investigaciones.

1. En este sentido, los errores de apreciación o de procedimiento en cualquiera de estos campos pueden llevar al investigador a formular conclusiones inexactas e incluso erróneas respecto del fenómeno que se pretende investigar.

2. En puridad, no es lo mismo "marcas de agua" que "filigranas", aunque en ocasiones se confunden los dos términos, básicamente por sus traducciones inglesa ("watermarks") y francesa ("filigranes"). Concretamente, la marca de agua sería la huella que queda en el papel, a través de la cual podemos ver pasar la luz (los ejemplos más cercanos para el lector actual serían las siluetas del perro en el papel de la marca Galgo, o las letras y escudo en el papel Gvarro), mientras que la filigrana sería el pedazo de alambre trabajado (retorciéndolo para formar esa silueta) que se coloca durante el proceso de fabricación del papel, con vistas a que deje impresa la silueta traslúcida deseada.

3. -José Sánchez Real: "Las filigranas del papel”, en Ligarzas, IV. Valencia, Departamento de Historia Medieval, Facultad de Filosofía y Letras, Universidad de Valencia, 1972, pp. 259-266.

4. A nivel general, "el estudio y conocimiento de las filigranas como ciencia histórica auxiliar comienza en el siglo XX, aunque nos podemos remontar a principios del siglo XX para encontrar trabajos como los de Briquet y Zonghi, todavía vigentes en la actualidad" (citado por: -Carmen Hernández García: "Orientaciones para la formación de un corpus de filigranas", en Normas internacionales para la catalogación de fuentes musicales históricas. RISM Serie A/II, Manuscritos musicales 1600-1850, edn. a cargo de José V. González Valle, Antonio Ezquerro, Nieves Iglesias, C. José Gosálvez, y Joana Crespí. Madrid, RISM-España, Anabad-Arco Libros, 1996, pp.162-168; para la cita concreta, véanse págs. 162 y 163).

5. -Fray Pablo Nassarre: Fragmentos Músicos repartidos en cuatro tratados en que se hallan reglas generales y muy necesarias para Canto Llano, Canto de Organo, Contrapunto, y Composición. Madrid, Imprenta Real de Música, 1700. [Edición facsímil y estudio de A. Zaldívar Gracia, Zaragoza, Institución Fernando el Católico, 1988]. Vid. página «Nota Editorial», donde José Navarro Casaus reproduce una única filigrana (familia "círculo"), ahí citada como "dos anillos con una cruz hueca en un extremo". 
dos de que he tenido noticia, inéditos hasta la fecha según mis últimas noticias, los dos únicos y pioneros trabajos existentes, de carácter local, que mencionaré a continuación, abren vías a futuras investigaciones, pero no solucionan el problema, por lo que el tema sigue estando sin roturar.

El primero de estos estudios sobre documentación musical se incardina en el magnífico catálogo de Dámaso García Fraile sobre el archivo catedralicio salmantino, y se encamina hacia la identificación de obras anónimas. Pero este trabajo concreto, que tan certeramente pretende abordar "caminos nuevos para nuestro país, pero viejos allende nuestras fronteras", lamentablemente, se nos queda reducido; apenas a una página de texto y a presentar 19 filigranas ${ }^{6}$. Todavía aquí se analiza este procedimiento como si se tratara de un "curioso y apasionante estudio", una disciplina aún joven en nuestro país (a pesar de que las primeras publicaciones sobre el tema se remontan al siglo anterior), y en definitiva, "uno de los sin duda numerosos y posibles puntos de arranque para la investigación" ". No le falta razón al anterior punto de vista, pero, en este sentido, es preciso fijar la seriedad del asunto y convenir con la profesora Cortès en que "el estudio y recopilación de las filigranas de nuestros venerables papeles hace tiempo que ha dejado de considerarse como un entretenimiento o divertimento erudito, un poco anecdótico y marginal [...], para pasar a convertirse en una inestimable ciencia auxiliar de la disciplina histórica"8.

Es precisamente el segundo estudio sobre el tema, de los mencionados anteriormente, correspondiente a la tesis doctoral de Paul R. Laird (sobre villancicos manuscritos conservados en el archivo de El Escorial) $)^{9}$, el primero en darse cuenta del gran problema que nos afecta: "Los textos estándar sobre marcas de agua contienen escasa cobertura sobre el siglo XVII, especialmente para España, y no existe bibliografía significativa sobre el papel español de dicho siglo. [...] un análisis completo de los datos sólo será factible a la luz de investigaciones posteriores"10.

Según J. Sánchez Real, "es seguro que el papel entró en Europa por España. Se tiene casi la certeza de que los molinos papeleros españoles fueron los primeros de Europa, según han repetido los historiadores extranjeros. Por otra parte no hay duda que estos molinos fueron los molinos de la región valenciana"11.

6. -Dámaso García Fraile: Catálogo Archivo de Música de la Catedral de Salamanca. Cuenca, Instituto Música Religiosa de la Diputación Provincial, 1981. [Cfr. pp. XIV-XVII].

7. -Dámaso García Fraile: op. cit.,p. XIV.

8. -Josepa Cortès: “Filigranes medievals de l'Arxiu Municipal de Sueca (1399-1500)", en Quaderns de Sueca, V. Departament de Paleografia i Diplomàtica, Universitat de València. Serie Inventaris, 6. Valencia, 1984, pp. 9-48. [Recoge 80 filigranas distintas].

9. -Paul Robert Laird: The Villancico Repertory at San Lorenzo el Real del Escorial, c. 1630-c. 1715. Ph. D., The University of North Carolina at Chapel Hill, 1986. [University Microfilms International, Dissertation Information Service, Ann Arbor, Michigan, 1987]. Sobre un total de 193 manuscritos en "papeles sueltos" estudiados (ca. 1800 hojas separadas, de las que 1259 llevan marca de agua), Laird diferencia seis categorías diferentes de filigranas, y una «clase X» (28 filigranas) de "marcas de agua que aparecen con menos frecuencia que los seis tipos precedentes" [la traducción es mía]. En total presenta 42 dibujos distintos, ofreciendo porcentajes de aparición de cada categoría respecto del total, y en general, aportando un estudio minucioso.

10. -Paul Robert Laird: op. cit., apéndice II, capítulo «Paper and Watermarks», p. 210. [La traducción de la cita es mía]. Todavía no hace mucho tiempo, ha aparecido en España el primer trabajo en el que se daban normas para la recogida y catalogación de filigranas procedentes de fuentes musicales, con un interesante artículo a cargo de la especialista de la Biblioteca Nacional de Madrid, Carmen Hernández García ("Orientaciones para la formación de un corpus de filigranas"..., vid. nota 4). En dicho trabajo, se ofrecen algunos ejemplos catalográficos de filigranas procedentes de fuentes musicales de dicha biblioteca, realizados por N. Iglesias y C. J. Gosálvez.

11. -José Sánchez Real: op.cit. (vid. nota 3). [Concretamente, se apunta a la localidad levantina de Játiva como cuna del papel en Europa. A este respecto, véanse los siguientes trabajos, todos ellos de ámbitos ajenos al específicamente musi- 
A partir de los últimos años del siglo XII y principios del siglo XIII, empezaron los fabricantes de papel a utilizar el procedimiento de colocar en sus productos - estamparles - unas siluetas, dibujos, o señales, que sirvieran para indicar su procedencia, para identificar el papel ${ }^{12}$. Y cómo no, el empleo de marcas de agua parece que también se habría extendido en la península ibérica a través de la región valenciana ${ }^{13}$. En este sentido, se ha insistido repetidamente en el supuesto origen italiano de muchas de las filigranas (y, por tanto, de los papeles en que están) halladas en documentos españoles ${ }^{14}$. Entretanto, Sánchez Real apunta que es muy probable que las fábricas francesas suministraran papel a Cataluña y otras regiones durante los siglos XIV-XVI ${ }^{15}$.

A la vista de lo expuesto, y como sugieren los profesores Córdoba y Cerezo ${ }^{16}$, es muy posible que el papel empleado en Aragón y Castilla durante los siglos XV y XVI fuera importado, al menos en una buena parte, de Italia (hasta donde he podido averiguar, no se habría investigado sobre etapas posteriores). Pero los mismos autores señalan también a continuación una evidente existencia de industrias papeleras en Játiva y otros lugares peninsulares, todavía por estudiar, sin descartar la hipótesis de que "artesanos locales, especialmente los levantinos, pudieron haber imitado esas marcas a partir de modelos italianos que ellos mismos habrían implantado y, en su caso, modificado para la realización de su propio papel". Lo que resulta obvio, es la gran pobreza comparativa en España de estudios en profundidad sobre las marcas de agua respecto de otros países europeos (sobre todo, Francia, Italia, Bélgica, Holanda, Inglaterra y Ale-

cal:] -C. Sarthou Carreres: Játiva, cuna del papel en Europa. Játiva, 1962. -Mª Luisa Cabanes Catalá; Milagros Cárcel Ortí;

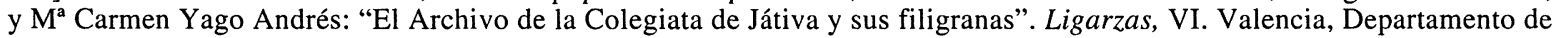
Historia Medieval, Facultad de Filosofía y Letras, Universidad de Valencia, 1974, pp. 5-120. [Sólo cubre los años 1357 a 1505].

12. Más concretamente, Córdoba y Cerezo señalan que "parece ser que el origen de las marcas de agua hay que buscarlo en la Italia del siglo XIII; esa innovación técnica, verdadera marca de fábrica impresa en la hoja en el momento de su fabricación, habría asegurado durante los siglos siguientes un puesto escogido al papel italiano en el mercado de los países de la Europa Occidental" (citado en: -Ricardo Córdoba de la Llave; y Manuel Cerezo Villegas: "Filigranas del Archivo Municipal de Córdoba (1450-1550)", en Anales de la Universidad de Alicante. Departamento de Historia Medieval, $\mathrm{n}^{\circ} 6$, Alicante, Imprenta de la Universidad, 1987 (1988), pp. 407-434; en este trabajo se recogen 294 filigranas distintas, y se aportan sus equivalencias, datación, etc.].

13. Y su área de influencia, que alcanzaría tierras murcianas: -Juan y Juana Ma Abellán Pérez: "Las filigranas medievales del Archivo Municipal de Murcia (1399-1455)", en Miscelánea Medieval Murciana, VI, Departamento de Historia Medieval, Universidad de Murcia. Murcia, Imprenta Nogués, 1980, pp. 133-146. [Recogen 186 filigranas distintas]. "En Murcia debió de existir una importante actividad con el reino de Valencia, basada en importaciones de papel".

14. -Francisco de A. de Bofarull y Sans: Los animales en las marcas del papel. Villanueva y la Geltrú, 1910. [Defiende aquí la procedencia italiana de todos los papeles con filigranas de animales]. -Charles Moïse Briquet: Les filigranes. Dictionnaire historique des marques du papier dès leur apparition vers 1282 jusqu'en 1600. 3 vols. París, Leipzig, 1923; reimp. 4 vols., Nueva York, 1966; Amsterdam, 1968 [edición facsímil con material suplementario]; Nueva York, 1977. [La obra fundamental en la materia, a pesar de que se realizara hace ya muchos años; clásico y amplio estudio sobre filigranas procedentes fundamentalmente de archivos italianos y franceses; recoge más de 16.000 filigranas europeas — con una pequeña representación española-, y aporta una de las primeras normativas al respecto; atribuye un origen italiano a las filigranas que representan figuras de anclas, anillos, carros, tijeras, flores con forma de tulipa y letras, todas ellas enormemente frecuentes en los documentos españoles]. -Jean Irigoin: "La introduction du papier italien en Espagne", en Papiergeschichte, X, 1960, pp. 29-32. [Estudia la introducción del papel italiano en España a partir del siglo XIII]. -Josepa Cortès: op.cit. (vid. nota 8). [Para esta autora, la mayoría de las filigranas que recoge en el archivo de Sueca denotan un origen italiano].

15. -José Sánchez Real: "Las filigranas de animales en los Archivos de Tarragona", en Boletín Arqueológico, 61-64. Instituto de Estudios Tarraconenses «Ramón Berenguer IV», Sección de Arqueología e Historia. Tarragona, Diputación de Tarragona, Sugrañes Hnos. editores, 1959. [Recoge 34 filigranas distintas].

16. -Ricardo Córdoba de la Llave; y Manuel Cerezo Villegas: op. cit. (vid. nota 12). 
mania $)^{17}$. Ello dificulta el poder establecer con garantías el origen de cada filigrana y de su respectivo soporte.

\section{El proceso de obtención del papel y las filigranas}

Desde finales del siglo XIII ${ }^{18}$, la elaboración del papel era muy sencilla (al igual que el proceso de obtención de las filigranas, ya descrito por varios autores) ${ }^{19}$. En resumen, sería éste, poco más o menos:

Determinadas materias primas, tales como tejidos usados (trapos, hilos) o algunos vegetales (cáñamo, lino, madera descortezada), se reducían en los molinos papeleros a fibras, que se separaban mecánicamente y se dispersaban en agua cociéndose a presión en una caldera. Luego, al producto resultante se le añadían algunas sustancias — colas, aglutinantes - para darle mayor cuerpo y consistencia, diluyéndose para obtener la pasta de papel. Ésta, una vez blanqueada y refinada, era mezclada y almacenada en unos depósitos o tinas, donde finalizaba la primera fase de su fabricación. De las tinas, se tomaba la cantidad suficiente para preparar artesanalmente cada hoja, lo cual se hacía vertiendo la pasta en un molde o "forma". Dicha forma, era un recipiente rectangular con un marco hecho de listones de madera y un fondo de hilo o tela metálica con una especie de retícula o trama a modo de cedazo, criba o tamiz ${ }^{20}$.

17. Véase a este respecto una interesante reflexión: -Germán Orduna: "Registro de filigranas de papel en códices españoles", en Incipit,I. Buenos Aires, Seminario de Edición y Crítica Textual. Consejo Nacional de Investigaciones Científicas y Técnicas de la Argentina, 1981, pp. 25-30; [recoge 9 filigranas distintas]: "Cada vez que hemos recurrido al libro clásico de Charles Moïse Briquet a propósito de un códice español, hemos comprobado la necesidad de un catálogo similar confeccionado con información extraída de archivos y bibliotecas de la península. Tanto la obra de Briquet como los tratados publicados en el siglo XIX y principios del XX y los más próximos, proporcionan datos sobre papeles usados en Francia, Italia, Alemania, Inglaterra, Países Bajos y otros reinos y regiones del centro de Europa, que en algunos casos aparecen en bibliotecas españolas o fueron usados en códices copiados en España, pero esto es información ocasional o lateral que el investigador induce. El libro de Bofarull y Sans (1903) y el más reciente de O. Valls y Subirá (1970) escasamente cubren la deficiencia. El dato que proporciona una filigrana confirma la fecha que sugieren las grafías y ocasionalmente ayudan a la filiación de un códice. Aunque algunos colegas se manifiestan decepcionados en sus intentos de filiación de manuscritos y ediciones españolas usando los datos que proporcionan las filigranas, creemos que esto se debe sobre todo a la falta de un catálogo que las reúna. La publicación continuada de filigranas o marcas tomadas de papeles usados en la península ibérica con fecha cierta de copia sería el paso previo para la confección de un catálogo sistemático" [las cursivas son mías].

18. Al parecer, las filigranas más antiguas que se conocen proceden de Fabriano (Italia) y datan de finales del siglo XIII. Como señala R. Valenzuela, "al principio, sus dimensiones son muy reducidas, y el dibujo es una silueta muy elemental. Entre finales del siglo XIII y comienzos del XIV adquiere grandes dimensiones, convirtiéndose en marca comercial. A fines del siglo XIV vuelve a disminuir. A comienzos del siglo XVI aparece la doble filigrana, añadiendo a la habitual otra complementaria, o una letra o número. De los siglos XVII al XIX vuelve la filigrana a adquirir un gran tamaño, pero como podemos comprobar [...] no siempre se respetan estas generalidades". (Vid.: -María Rosario Valenzuela Marco: "Filigranas en el Archivo Histórico Provincial de Teruel", en Teruel, LXXXV/2, 1997, p.62).

19. -José Sánchez Real: op. cit. (vid. nota 3). -Josep $\mathrm{M}^{\mathrm{a}}$ Madurell i Marimón: El paper a les terres catalanes. Contribució a la seva Història. 2 vols. Barcelona, Fundació Salvador Vives Casajuana, 1972. -M. Th. Gerardy: "Les techniques d'examen des filigranes", en Les techniques de laboratoire dans l'etude des manuscrits, París, 1974, pp. 143-157. -Ricardo Córdoba de la Llave; y Manuel Cerezo Villegas: op. cit. (vid. nota 12).

20. En el fondo de la forma — - cedazo-, y junto a la filigrana, había unos pocos hilos, separados, puestos en la dirección menor (la dirección vertical del pliego) llamados corondeles y muchos otros hilos muy juntos, puestos en la dirección mayor (dirección horizontal del pliego), llamados puntizones. Sobre la trama que forman los corondeles y los puntizones se destaca la filigrana, que, en general, está en la parte central. Tanto los corondeles como los puntizones (que al principio debieron ser filamentos de bambú, terminando por ser metálicos), pueden contribuir a la datación de los documentos. Sin embargo, el empleo de ninguno de ellos resul-

Anuario Musical, 55 (2000) 
La segunda fase del proceso consistía en llenar el molde o forma con pasta de papel, y eliminar el agua contenida en dicha pasta mediante su escurrido a través de la tela metálica de la forma $^{21}$. Si sobre el retículo de la forma se colocaba un dibujo hecho con hilo vegetal o metálico (generalmente, alambre), a modo de señal, distintivo o marca, de suerte que aparecía en relieve, en la capa de pasta que se depositaba para formar la hoja de papel (que tenía el mismo nivel o grueso en toda la forma) quedaba marcada su huella —el dibujo-, al hacerse dicha capa más delgada por la zona que entraba en contacto con el dibujo (que recibía por tanto menos pasta). Con ello se conseguía hacer visible dicho dibujo (la marca de agua) al trasluz, al resultar más traslúcido que el conjunto de la hoja ${ }^{22}$.

El tercer paso a seguir era el secado de la hoja de papel: una vez escurrida la pasta, se desmontaba la forma, soltando los listones que formaban el marco, y se dejaba la capa u hoja de pasta, sobre material poroso - un secante hecho con un trozo de tejido, normalmente de fieltro-, que acababa por absorber el exceso de agua. Sobre cada hoja se colocaba un trozo de secante y una nueva hoja de pasta de papel, con lo que se formaban grandes pilas. A continuación, se escurría la pila por presión, se separaban las hojas, y se tendían en un lugar aireado que permitiese un secado rápido (generalmente, en tendederos colocados en el último piso de las papelerías o molinos papeleros). Algunas veces, el papel recibía un acabado de satinado y encolado. Por último, el papel —de mejor o peor calidad según múltiples condicionantes-, salía del molino papelero dispuesto para su comercialización, que se hacía siempre agrupando las hojas en resmas como unidad de medida $(1 \text { resma }=20 \text { manos }=500 \text { pliegos })^{23}$.

ta definitivo como método de datación, pues la distancia entre ellos varía en una misma época y sólo se ha visto un gran cambio entre los siglos XV y XVI, cuando se acorta el espacio que separa a los corondeles (más bien, este cambio - la reducción de distancia entre corondeles y entre puntizones - anuncia una mejora técnica en la calidad del papel, que se hace más refinado). Así, cuando la pasta del papel se trabaja poco y mal, porque los medios no lo permiten hacer mejor, las fibras son largas y gruesas, y por lo tanto la criba formada por los corondeles y puntizones puede tener una luz grande. Si la preparación de pasta mejora, las fibras son más trabajadas, se hacen más cortas y finas, y esto obliga a cerrar la luz de la malla de la forma, para que al fabricar la hoja de papel no pase toda la pasta a través de la red de hilos formada por los corondeles y puntizones y se haga inútil el trabajo. Por otra parte, el profesor Orduna señala un hecho que he podido comprobar en la práctica, y es que "no siempre es posible, por falta de nitidez o de iluminación suficiente, tomar la distancia entre los puntizones y aún entre los corondeles" (vid.: -Germán Orduna: "Registro de filigranas de papel en códices españoles", en Incipit, V. Buenos Aires, Seminario de Edición y Crítica Textual. Consejo Nacional de Investigaciones Científicas y Técnicas de la Argentina, 1985, pp. 5-10; [recoge 8 filigranas distintas]). Por otro lado, las medidas o dimensiones del marco de madera, de las formas (lo que es lo mismo que decir que el tamaño de la hoja de papel), variaron con el tiempo, a pesar de que su luz se correspondía con los módulos en uso obligatorios establecidos en cada momento, y que eran marcados por la ley. Dichas medidas se relacionaban con los patrones o unidades de longitud entonces usadas, aunque no con estricta precisión. Por otra parte, era habitual el recortar las hojas de papel por sus bordes para hacer desaparecer las barbas.

21. Al tiempo que se hacía esta operación, se movía la forma para que se entrecruzaran las fibras exprimidas, mientras escurría el agua a través de la trama. De este modo, las fibras se entrecruzaban longitudinal y transversalmente, quedando sobre el tamiz una capa delgada de pasta húmeda que al estar pegada al fondo reproducía, en negativo, las irregularidades y líneas de la trama.

22. Por la misma razón, sucedía lo mismo con los corondeles y puntizones, que también pueden distinguirse al mirar el papel al trasluz. En líneas generales, puede afirmarse que esta técnica de obtención de la marca de agua (en última instancia, el elemento que nos servirá para intentar averiguar la fecha del escrito redactado sobre el papel), inventada en el siglo XIII, y que se aplica tanto al papel destinado a ser impreso como al manuscrito, apenas ha cambiado con el paso de los siglos, subsistiendo hasta nuestros días.

23. La calidad del papel estaba - entonces como hoy - en función de múltiples factores, como su dureza, rigidez y grosor. Su relativa facilidad, o su resistencia, a la rotura, era un factor determinante de su calidad, ligada, muchas veces, más al proceso de fabricación (mayor o menor elaboración de la pasta), que a las materias primas. No obstante, puede decirse que en los primeros tiempos -i.e., durante la Edad Media - el papel era grueso y esponjoso, y se apreciaban en él las fibras largas originales, conforme correspondía a la rusticidad de las máquinas empleadas durante su fabricación. Con el paso del tiempo, las fibras se hicie- 


\section{Utilidad de las filigranas y marcas de agua:}

El elemento principal de esta exposición, la filigrana (y su plasmación concreta en marca de agua sobre el papel), considerada como marca de fabricante, constituye un distintivo del origen del papel y representa una garantía de la calidad del material, siendo "un elemento cronológico de primer orden, ya que de su observación se puede deducir la fecha aproximada de un manuscrito que no la posea, al ser comparada con la que presentan otros debidamente datados" 24 . Su utilidad como elemento auxiliar para la disciplina histórica y paleográfica ${ }^{25}$ (y por tanto, también para la Musicología histórica) es múltiple, pues sirve para:

- Hacer un estudio intrínseco del papel y de su fabricación (conocimiento de la industria del papel).

- Identificar el lugar de origen - la procedencia- del soporte físico.

- Adivinar las zonas de difusión y área de influencia de determinadas fábricas, averiguar el tiempo durante el cual estuvieron los molinos papeleros en actividad, y trazar las rutas comerciales y los puntos finales de destino de la producción papelera. A partir de ahí, estudiar la situación económica derivada, las relaciones comerciales, y sus posibles causas políticas o sociales.

- Apoyar valiosamente la datación de textos, literarios y documentales, cuya cronología resulte dudosa o incierta por ausencia de referencias temporales (la identificación de las marcas de agua puede contribuir a fijar unas fechas aproximadas a la confección del texto estudiado). Del buen conocimiento de los tipos de filigranas y las fechas en que se usaron, dependerá en buena medida el que se pueda conocer la fecha en que se fabricó un determinado papel, y por consiguiente, la fecha aproximada en que fue escrito.

Pero como señala Sánchez Real, "todo este campo de trabajo puede decirse que está sin roturar. Las filigranas de nuestros archivos no son conocidas, y su estudio está por hacer. [...] La historia del papel en España está por hacer"26.

ron cortas, por la mejor preparación mecánica de la pasta, el papel perdió porosidad, se hizo más delgado, y el acabado fue mejorando, perfeccionándose su calidad.

24. - $\mathrm{M}^{\mathrm{a}}$ Desamparados Cabanes Pecourt; y $\mathrm{M}^{\mathrm{a}}$ Luisa Cabanes Catalá: "Las filigranas del Archivo Municipal de Estella", en Príncipe de Viana, 136 y 137. Institución Príncipe de Viana, Diputación Foral de Navarra. Pamplona, ed. Aranzadi, 1974, pp. 483-505. [Vid. p. 483].

25. Como manuales de paleografía literaria, pueden seguirse: -A. Millares Carlo: Tratado de Paleografia española. Ensayo de una historia de la escritura española desde el siglo VIII al XVII. Madrid, 1929. -Ángel Canellas: Exempla Scripturarum Latinarum. In usum scholarum. Pars altera. Zaragoza, Librería General, 1974. Como manual de paleografía musical, sígase el tratado de -Willi Apel: The Notation of Polyphonic Music 900-1600. Cambridge, Massachusetts, The Medieval Academy of America, 1942. También, de interés para nuestro trabajo: -Samuel Rubio Calzón: La polifonía clásica. El Escorial, La ciudad de Dios, 1956. -Ramón Adolfo Pelinski: "La polifonía vocal española del siglo XVII y sus formas de escribirla", en Anuario Musical, XXIV, 1969 (1970), pp. 191-198. -Miguel Querol Gavaldá: Transcripción e interpretación de la Polifonía Española de los siglos XV y XVI. Madrid, Comisaría Nacional de Música, 1975. -Richard Rastall: The Notation of Western Music. New York, 1978.

26. -José Sánchez Real: op. cit. (vid. nota 3). 


\section{Naturaleza de las filigranas y marcas de agua. Problemas que presentan:}

Un elemento realmente importante para conocer la naturaleza de las filigranas y su utilidad de cara a la datación de documentos tanto impresos como manuscritos, es prestar atención al hecho de que el dibujo o matriz de la filigrana se trabajaba a mano en alambre, y se solía hacer por parejas. Por su método de fabricación, era imposible que hubiera dos parejas idénticas de alambres, puesto que cada una, hecha manual e independientemente (es decir, sin molde), daba marcas distintas, siquiera fuese con pequeñas variaciones, máxime en un material como el hilo metálico, de relativa rigidez. Es por ello que no puede haber dos formas con filigranas idénticamente iguales, y que la marca de agua es un elemento diferenciador clave de todos y cada uno de los papeles que la lleven. Así, podemos concluir que si hallamos dos filigranas iguales, responderán a la misma forma y habrán salido del mismo taller y bandeja con un intervalo de tiempo relativamente corto, por más que aparezcan en papeles muy alejados entre sí geográficamente ${ }^{27}$.

Comoquiera que el papel se consume rápidamente en condiciones normales, y se deteriora fácilmente (sobre todo el fabricado en épocas en que la técnica no estaba muy desarrollada), la aproximación que se consigue en la datación es grande. No obstante, hay que ser conscientes de que esta técnica se basa en estimaciones aproximativas: de momento, lo único realmente cierto es la coincidencia cronológica de las formas en un espacio de unos veinte años, pasado el cual desaparecen.

Se impone, pues, una primera etapa de trabajo en la que se recojan el mayor número de filigranas posible, con vistas a elaborar amplios inventarios o catálogos generales (debido a que la identificación de marcas de agua se hace por comparación, a mayor número disponible de éstas, mayores posibilidades tendremos de localización y consiguiente datación) ${ }^{28}$.

Hasta ahora, cuanto se ha explicado ha sido suponiendo unas condiciones normales, es decir, que el papel se ha comprado y utilizado cuando ha sido necesario, al poco tiempo de su fabricación, y por lo tanto pueden considerarse papel y escritura del mismo tiempo. Pero pueden darse situaciones contrarias. Sabido es que nuestras catedrales, por ejemplo, — dado que en ellas se conserva buena parte de nuestra documentación musical-, adquirían habitualmente las resmas de papel necesarias para su administración ${ }^{29}$. Por otro lado, el papel comprado se distribuía

27. Debido al uso, la filigrana cambiaba lentamente de posición en la forma, y sus contornos se iban deformando, por lo que al cabo del tiempo se desechaban. Por ello, se estima que una pareja de alambres podía durar, en buenas condiciones, aproximadamente un año. Las filigranas que difieren ligeramente se llaman similares; y aquellas con diferencias mayores, divergentes. Se consideran similares las hojas de papel salidas de la misma forma en el espacio de unos meses (puesto que hay pequeñas diferencias entre las primeras y las últimas).

28. Sobre la técnica y procedimientos habituales para la recogida de marcas de agua -metodología que he seguido en este trabajo-, véase lo expuesto en los siguientes estudios: -José Sánchez Real: op. cit. (vid. nota 3), especialmente los apartados "Procedimiento para copiar filigranas", y "Datos complementarios". -Id.: "Criterios a seguir en la recogida de filigranas", $i b i d .$, VI, Valencia, 1974, pp. 361-371. -Carmen Hernández García: "Orientaciones para la formación de un corpus de filigranas"..., op.cit., p.163 (vid. nota 4). (Este último trabajo cita también algunos de los procedimientos más modernos para la recogida de filigranas, como p.ej. la Betagrafía, Rayos X, Fotografía y digitalización por ordenador).

29. En este sentido, he localizado entre la documentación capitular del siglo XVII en Zaragoza, algunos datos relativos a los gastos ocasionados al cabildo de La Seo por la adquisición de papel y pergamino destinado a los libros de coro, aunque los gastos por papel apenas se especifiquen como tales, refiriéndose apenas los desembolsos por pergamino. (Nótese el nombre francés del primer pergaminero citado, en relación con el elevado porcentaje de población francesa -en su mayoría comerciantes- 
entre las diversas necesidades capitulares: archivo general, secretaría, juntas de fábrica, "quinque libris", gastos y administración de sacristía, capilla de música, etc., de suerte que los papeles destinados específicamente a la música serían sólo una parte respecto del total, que pudiera haberse separado del conjunto en fecha cercana a su compra, o no.

Y tampoco hay que olvidar las prácticas eclesiásticas de la época - y posteriores- en el sentido de aprovechar absolutamente todo y no tirar nada ${ }^{30}$, práctica que dificulta aun más una correcta datación documental únicamente a partir de las marcas de agua. En todo caso, el papel adquirido por una catedral, en condiciones relativamente "normales", podía quedar apilado, de suerte que al llegar a la base del montón de papel podían haber transcurrido unos pocos meses, e incluso años. También es muy posible que el amanuense aprovechara alguna vez papeles cortados de pliegos viejos sin usar, o simplemente pliegos traspapelados. Éstas, y algunas otras situaciones por el estilo, pudieran dificultar una buena datación a partir del estudio de las marcas de agua, por lo que resulta imprescindible tenerlas muy en cuenta y ser especialmente prudentes a la hora de aventurar una posible datación: la mejor datación que pueda ofrecerse, no será, pues, aquélla que sólo se asiente en el estudio de las filigranas, sino aquélla, que, al análisis de las marcas de agua, añada otro tipo de condicionantes para la datación (tipo de tinta utilizada, caligrafía del copista, etc. $)^{31}$.

\begin{abstract}
que residía y ejercía sus actividades en Zaragoza a lo largo de todo el siglo XVII). Según el Libro de fábrica de La Seo de los años 1600 a 1619, se cita lo siguiente: Año 1618: Gasto desde el 1-IV-1618, hasta el último de-VII-1619:[se paga:] "En 2 de Junio di a Jaques de Borbon por 40 dozenas de pergaminos...60£”. Año 1624: Gastos de la Fábrica: "A Jaques Borbón pergaminero por 18 Doçenas de pergaminos para el salterio". 1624: "A fray Alberto de Azpeliqueta carmelita calçado a quenta de los libros que açe para la iglesia". Año 1625: "A frai Alberto Esperiqueta del Carmen setenta y nuebe libras dos sueldos por 2[borrón]6 ojas a 7s del libro del psalterio" [Aparte, otros cobran por la encuadernación y guardas de dicho libro]. Año 1630: Gastos ordinarios y extraordinarios:"A Matheo de Grazia por una doçena de Veçerros p adrezar los libros de coro". Año 1691: Gastos extraordinarios:"Pedro Alambra por el pergamino, y escribir el officio de s.ta Eulalia".

30. Más que a posiciones de economías sumamente ahorradoras - aunque también-, no hay que olvidar que, en estos casos, la actitud tomada por parte de la Iglesia tenía unas razones cultuales: el papel servía para contener rezos u otros aspectos relacionados con el culto - música litúrgica, p.ej._, y del mismo modo que no podía desecharse alegremente un cáliz o una casulla en mal estado, tampoco podía tirarse el papel en mal estado o "infra"-utilizado. Gracias a esta "política", se nos ha conservado la práctica totalidad del patrimonio histórico-musical documental eclesiástico de que hoy podemos disponer (y gozar) para su estudio. A esto mismo responden también tantísimas reparaciones y re-aprovechamientos documentales, palimpsestos, pergaminos musicales que sirvieron a posteriori como tapas para encuadernar o guardas para contener protocolos u otro tipo de documentación, e incluso papeles de música para "parchear" tubos en nuestros órganos históricos, etc., materiales, que, de otro modo, no se nos hubieran conservado.

31. José Sánchez Real (op. cit,vid. nota 3), ya nos advierte al respecto: “Aunque el papel es materia que fácilmente se estropea y pierde sus cualidades (aspecto, color, resistencia mecánica, etc.) si no está protegido, algunas veces aparecen escritos de una fecha sobre papel quince o veinte años más antiguo. Ordinariamente esto ocurre cuando el texto tenía, para el que lo escribía, poca trascendencia y podía utilizar para ello papel «viejo»: relaciones, notas, albaranes, borradores y otros. En tal caso: por la filigrana el texto puede parecer más antiguo de lo que es en realidad; o por el texto, el papel y sus filigranas considerarse como más moderno de lo que es en realidad. Otras veces, al archivarse, coserse o encuadernarse los escritos, el que lo hizo utilizó para cubrir los cuadernillos, formar cubiertas, darle más cuerpo al volumen, o escribir los índices, pliegos de papel en uso en el momento de hacer esta operación. Si es así, aparecen discordancias entre las filigranas del volumen, que son necesarias de vigilar: las filigranas de los papeles añadidos pueden suponerse más antiguas de lo que en realidad son o si se da inadvertidamente valor al papel y sus filigranas que los escritos se hagan más modernos. Más raro es el hecho que aparezca un texto antiguo sobre papel con filigrana moderna. En tal caso es un traslado, o una copia de un original, o una falsificación. De ahí que dadas las consecuencias que pueden tener, es conveniente, en la tarea de recogida de filigranas, asegurarse bien de la fecha que se le asigna”.
\end{abstract}




\section{Clasificación de filigranas y marcas de agua}

Otro aspecto importante para el trabajo con marcas de agua es el de contar con una clasificación normalizada de las mismas (una terminología común), factor que hasta hace poco tiempo no estaba solventado, utilizando cada estudioso una terminología diferente para designar a cada grupo de filigranas. Sánchez Real terminó con el problema: recogió lo mejor de cada autor, limó errores y sintetizó, aportando una clasificación lo más esquemática posible. Básicamente, esta clasificación se reduce a tres apartados jerarquizados, a saber: familia, tipos y variantes ${ }^{32}$.

De este modo, la familia (o tema) sería la formada por todas las filigranas que presenten un determinado dibujo o figura (p.ej., la familia "águila"); ésta se dividiría en tipos, tantos como diferencias importantes se observen en el tema (las diferencias pueden concretarse a elementos nuevos aparecidos en el dibujo). En cada uno de los tipos las variantes corresponderán a las filigranas de un mismo tipo que se diferencien notablemente en su tamaño, forma del dibujo, o posición de los elementos característicos. Hay que hacer constar además que esta clasificación está siempre abierta a los nuevos hallazgos y a los cambios que suponga el paso de variante a tipo cuando los datos recogidos lo permitan o lo exijan. Para el caso de los archivos españoles, destacan por su abundancia algunas familias determinadas, tales como las manos, carros, montes, animales, letras, tijeras, anillos, cruces, flores y rostros humanos, cada una de las cuales cuenta con un gran número de variantes.

Sánchez Real propone que "para la ordenación de las filigranas es recomendable no hacerlo por fechas, sino por temas y éstos por orden alfabético del nombre que sirva para designar el motivo de la filigrana. Una vez ordenadas las filigranas puede aplicarse una única numeración". Y apunta por otro lado un aspecto clave, y es que "la importancia de una filigrana está no sólo en ella, sino en la relación que tenga con las otras que forman el fondo que se estudia" ${ }^{\text {" }}$. Por lo tanto, hay que insistir en la necesidad de disponer de un número suficiente —un buen catálogo- de estas figuras.

\section{Antecedentes para el estudio de las marcas de agua en los manuscritos de música del siglo XVII de las catedrales de Zaragoza:}

Para centrarnos en el estudio de las filigranas zaragozanas del siglo XVII, es también preciso plantear unos antecedentes inmediatos. Como sugieren Córdoba y Cerezo, durante el siglo XVI, las filigranas estuvieron sometidas a una rápida evolución; poco a poco se produjo una "progresiva sustitución de los dibujos simples, de trazos sencillos e irregulares, que aparecen en los documentos más antiguos (carros, montes, círculos, animales), por los más complicados y

32. No obstante, C. Hernández todavía señalaba recientemente que "la terminología utilizada para la clasificación de las filigranas está en estudio aún en España. Se espera que en el II Congreso Nacional de Historia del Papel en España y sus filigranas que se celebrará en Cuenca en 1997 se puedan dar conclusiones" (citado en: -Carmen Hernández García: "Orientaciones para la formación de un corpus de filigranas"..., op. cit., p.163 - vid. nota 4-).

33. -José Sánchez Real: ibid.

Anuario Musical, 55 (2000) 
artísticos de los papeles más modernos (anillos, jarrones, escudos, pájaros), que llegarán en el siglo XVIII a hacer de las filigranas auténticas maravillas" ${ }^{\prime 34}$.

Para la identificación del conjunto de marcas de agua recogidas en el Archivo de Música de las Catedrales de Zaragoza, he utilizado numerosas fuentes secundarias y bibliografía. Sin embargo, a la luz de toda la información recogida, se ha revelado sumamente difícil identificar quiénes pudieron ser los fabricantes -o papeleros - del papel aquí conservado. Por ello, dado que los dibujos varían usualmente demasiado para una identificación precisa, el proceso de identificación de las filigranas se fijará sobre todo en las ideas básicas de carácter general (comparación de familias y tipos), más que en la identificación particular de marcas de agua concretas o sus variantes.

Las principales fuentes existentes de interés para nuestro estudio a nivel internacional resultan poco útiles para nuestros propósitos. La fuente fundamental, básica, Briquet ${ }^{35}$, sólo llega hasta las proximidades del año 1600 , por lo que, en principio, parece que las similitudes que pudieran hallarse nos llevarían a unos orígenes del papel zaragozano demasiado remotos, lo que no parece muy creíble. A pesar de ello, en dicho trabajo se pueden encontrar algunas filigranas similares a las aragonesas. Tan sólo otras dos fuentes a nivel internacional extienden su cobertura hasta el siglo XVII: de nuevo Briquet ${ }^{36}$, y Churchill $^{37}$. Pero tras revisar toda la bibliografía disponible, todavía muchas de las filigranas zaragozanas se han revelado, hasta la fecha, como desconocidas. En este sentido, tan sólo podemos conjeturar la posible procedencia de los papeles zaragozanos de las zonas limítrofes, colindantes, o al menos no muy lejanas, como parece lo más lógico, lo que nos conduce en primer lugar hacia los molinos papeleros situados en la antigua Corona de Aragón (Cataluña, Valencia, Aragón). Veamos lo que sucede con cada una de las posibles procedencias apuntadas:

-Valencia: "Valencia, que tanto impulso dio a la fabricación del papel, desaparece durante los [siglos XV y XVI]. Poco o nada se ha podido saber sobre la elaboración del papel durante los siglos XV y XVI. [...] Con seguridad esta crisis papelera valenciana fue debida al gran comercio que Valencia sostenía con Génova, y al mismo tiempo, al gran número de mercaderes que desde dicha ciudad italiana, se habían aposentado en la ciudad del Turia"38. Parece ser que en el siglo XVII la crisis continuaba: "Si bien la decadencia en la fabricación del papel se dejó sentir durante todo el siglo XVII en la totalidad del País Valenciano, no sucedió lo mismo durante el siglo XVIII, pues en toda esta área resurgió con gran empuje la industria papelera, principalmente en Alcoy y en sus alrededores, lugar que pasó a ser uno de los centros papeleros más

34. -Ricardo Córdoba de la Llave; y Manuel Cerezo Villegas: op. cit. (vid. nota 12).

35. -Charles Moïse Briquet: Les filigranes. Dictionnaire historique des marques du papier dès leur apparition vers 1282 jusqu'en 1600. 3 vols. (reimpr. en 4 vols.). Ginebra, 1907; París, Leipzig, 1923; Nueva York, 1966; Amsterdam, 1968 (edición facsímil con material suplementario); Nueva York, 1977. 1888 .

36. -Charles Moïse Briquet: Papiers et filigranes des archives de Gênes 1154 à 1700. Ginebra, H. Georg libraire-éditeur,

37. -W. A. Churchill: Watermarks in paper in Holland, England, France, etc. in the XVII and XVIII Centuries and their interconnection. Amsterdam, Minno Hertzberger, 1935.

38. -Oriol Valls i Subirà: La Historia del Papel en España. 3 volúmenes. I: Siglos X-XIV; II: Siglos XV-XVI; III: Siglos XVII-XIX. Madrid, Empresa Nacional de Celulosas, 1978, 1980 y 1982, respectivamente. [Vid. vol. II, p. 69]. 
importantes de toda España. Desgraciadamente, Játiva, debido a su devastación por las huestes del rey Felipe V, dejó de elaborar papel, y nunca más volvió a ser lo que fue"39. De este modo, los molinos valencianos, anteriormente los más activos de la península, desarrollan una baja producción a lo largo del siglo XVII, la cual, todavía en gran medida, queda por estudiar.

-Cataluña: según el profesor Valls, "es Felipe III quien abre las puertas a la conciencia de los papeleros y les da facilidades a fin de que puedan adquirir el suficiente trapo para la confección del papel. Es entonces cuando el papel catalán, que a pesar de los pesares era conocido en toda España y llegaba incluso a América y a Filipinas en ínfimas cantidades, infiltrándose entre las partidas del papel italiano o francés, ve abierto su mercado de tal forma, que llega a cubrir toda el área hispana"40. Posteriormente, las circunstancias políticas vividas desde 1640 y hacia mediados del siglo XVII —etapa en que Aragón y Cataluña se veían enfrentadas por la guerra de "Els Segadors"-, no parecen las más propicias para un intercambio comercial de papel. Y sin embargo, según el mismo Valls comenta convencido, "incluso en las épocas difíciles en que las guerras podían poner obstáculos al libre comercio, pronto se arreglaban las cosas, prescindiéndose de las tiranteces políticas, en bien de una economía mutua". Algo parecido sucedería con Francia, país con el que se estaba en guerra, pero con el que, aun a pesar de las prohibiciones, se mantenía un comercio muy fluido desde Aragón a través de los puertos pirenaicos. Por otra parte, hay que pensar en la numerosa colonia francesa afincada en tierras zaragozanas, formada en su mayor parte por mercaderes, artesanos y pequeños comerciantes, y en el hecho, no menos importante, de que era precisamente el papel francés, junto con el italiano, el que monopolizaba los mercados a escala mundial.

-Aragón: prácticamente nada sabemos sobre la existencia de molinos papeleros en esta comunidad antes del siglo XVII, y muy poco realmente hasta bien entrado el XVIII. Apenas un estudio sobre la pequeña localidad turolense de Mosqueruela ${ }^{41}$. Su número debió de ser muy escaso. Aparte de debido a la escasa atención que se ha prestado al tema hasta ahora, pensamos que habrán influido también las grandes cantidades de agua que se hacían necesarias en los molinos para la manipulación y proceso del papel, siendo éste un bien muy preciado y bastante escaso en tierras aragonesas. Veamos lo apuntado al respecto por Valls: "Los molinos papeleros más conocidos en Aragón son relativamente pocos y casi todos los podemos situar entre los siglos XVII y XIX, salvo el molino antiguo de Beceite, que parece fue construido para el servicio de la Orden de Calatrava a mediados del siglo XIV y del cual existen [...], los restos de sus paredes; pero, por lo que se ha visto, pudieran ser más recientes" ${ }^{\prime 2}$. No obstante la penuria de datos sobre el siglo XVII, sabemos que "Aragón, durante el siglo XVIII y parte del XIX, ocupó un buen lugar

39. -Id.: Ibid. [vid. vol. III, p. 257].

40. -Id.: Ibid. [vid. vol. III, p. 145].

41. -Luis Ariño Rico: "Filigranas de Mosqueruela", en Ligarzas, VI. Valencia, Departamento de Historia Medieval, Facultad de Filosofía y Letras, Universidad de Valencia, 1974, pp. 121-359.

42. -Oriol Valls i Subirà: op. cit., - vid. nota 38-. [Específicamente sobre la historia del papel en Aragón, $c f r$. vol. III, pp. 130-143, y sobre sus filigranas, pp. 139-143; para esta cita concreta, vid. p. 131]. 
entre la fabricación papelera española" ${ }^{43}$, siendo sus principales centros papeleros Beceite, Valderrobres y Calamocha, como vemos, todos ellos, junto a Mosqueruela, centros situados en la provincia de Teruel, la más cercana a tierras valencianas (del siglo XVIII datarían ya los molinos de Huérmeda y Graus). Así pues, tan sólo sabemos de la existencia de molinos papeleros en tierras aragonesas en el siglo XVII, pero este tema todavía no se ha estudiado.

\section{Marcas de agua en los manuscritos de música del siglo XVII de las catedrales de Zaragoza:}

Tras revisar lo que sucedía en el área de la antigua Corona de Aragón, estamos casi como al principio. Simplemente sabemos algo más al respecto, pero las dudas que teníamos siguen sin despejarse. Se hace obligado, pues, referirse a los ejemplos concretos que he recogido en busca de nueva luz. Se trata de toda la documentación musical fechada del archivo zaragozano, desde comienzos del siglo XVII hasta el año 1645, así como de algunos otros ejemplos sin fechar, fundamentalmente referidos a composiciones del maestro de capilla de El Pilar, Urbán de Vargas, que desempeñó dicho cargo entre 1645 y 1651, y de nuevo en 1653. En total suponen 84 filigranas diferentes, amén de otras muchas recogidas que no he incluido aquí por hallarse repetidas. Como se verá, al tratarse de música "a papeles" (i.e., no anotada en partitura, sino en partes sueltas), es frecuente el caso de que los diferentes papeles de una misma composición presenten filigranas distintas, denotando así un origen diverso de dichos papeles ${ }^{44}$.

Veamos ahora las filigranas recogidas, agrupadas por familias, y dispuestas por orden alfabético:

- Las filigranas números 1 al 54, correspondientes a la familia "círculo" [tipo "tres círculos"], muy frecuentes en el archivo zaragozano, abundan particularmente en tierras españolas (Sevilla, Toledo, Madrid). El profesor Valls ha tratado esta familia de filigranas, de origen italiano -y más concretamente, genovés-, más tarde imitado en Francia, con cierto detenimiento ${ }^{45}$.

43. -Id.: Ibid. [vid. vol. III, p. 131]. Aquí, Valls ofrece los nombres de algunos papeleros aragoneses, aunque no indica en qué época concreta ejercieron su labor; son éstos: Soria, Cortés, y Carner (de este último señala que trabajó "más modernamente"). Asimismo, destaca la importancia del "Molí bonic" de Beceite, situado junto al río Pena, y muestra única en Europa de un molino estucado al estilo renacentista - pompeyano - del que quedan restos de algunas de sus pilas, y pinturas en sus paredes de animales exóticos, y referentes a temas papeleros (una prensa). A pesar de sus valiosas informaciones, las únicas 9 filigranas aragonesas que nos da Valls, son todas de fines del siglo XVIII o posteriores.

44. Este hecho es corroborado por P. R. Laird (op. cit., - vid. nota 9- p. 211), cuando señala que [la traducción es mía] "las colecciones en partitura [libros y cuadernos] contienen muchas veces las mismas filigranas, mientras que se puede encontrar una mayor variedad en las múltiples hojas de las copias para la interpretación [es decir, en los papeles sueltos]". De los 193 manuscritos que analiza, más de 60 villancicos presentan más de una filigrana, posiblemente mostrando que fueron copiados sobre papel de más de un sumịnistrador. El resto, muy posiblemente habrían sido copiados en papel procedente de un único proveedor.

45. - Oriol Valls i Subirà: op. cit. — vid. nota 38- [vid. vol. III, p. 29:] "Las filigranas de los tres círculos, con el escudo de Génova en el primero, son todas procedentes de los molinos de los alrededores de la ciudad de Génova. Esta fabricación, que podemos asegurar que fue masiva, se hizo frente al mercado español. Quizás por eso algunos historiadores las han creído de fabricación hispana. En Francia, y también para el mercado español, se imitó esta marca con el nombre de Trois $O$ ”. [Y el mismo autor, en la página 58 explica que:] "Las filigranas de origen francés, [...], se hallan más diseminadas por el norte de la península, y también en Andalucía, pero en menos cantidad. En Valencia y Cataluña la cantidad es escasa, muy inferior a la italiana". 
Por otra parte, existen variantes de este tipo con las más diversas procedencias, recogidas en el catálogo de Briquet: № 3245 (Bruselas, año 1552); № 3246 (Bruselas, año 1598 -variante en el círculo inferior, en Perpiñán, post. 1639-); No 3247 (Génova, 1548); No 3248 (Milán, 1560); Nº 3249 (Desana -Mantua-, 1565 — variante ident. Alejandría, 1565-); No 3250 (Milanesado, 1570). Entre las recogidas en el archivo zaragozano (en adelante, $E$ : $\mathrm{Zac}$ ), se hallan las siguientes:

\section{Tres círculos:}

\section{Rematados por una cruz:}

1.1. con el círculo superior en blanco: filigranas en mi estudio números 1 (signatura, $E$ : Zac, B-3/48), y 2 (B-13/240; copia musical del año 1647).

1.2. con media luna en el círculo superior: [filigranas similares a las que ofrece Oriol Valls i Subirà con los números 25 (Cáceres -Guadalupe-, 1725, papel genovés de Steffano Patrone), $\mathrm{N}^{\circ} 26$ (Cáceres - Guadalupe-, 1740), y № 30 (Madrid, 1757), de origen genovés; y $\mathrm{N}^{\circ} 1$ (Toledo 1601), de origen francés]: filigranas de mi estudio 3, 4, 5 y 6 (signatura $E$ : Zac, B-3/37), 7 y 8 (B-3/42), 9 (B-3/50), 10, 11 у 12 (B-13/236), 13 (B-13/237), 14 (B-32/520), 15 (B-4/51; copia musical del año 1639), y 16 (B-62/886; copia musical de 1639) ${ }^{46}$. Paul R. Laird también ofrece algún ejemplo de filigranas de este tipo conservadas en El Escorial ${ }^{47}$. Personalmente, ofrezco otra variante existente en e! fondo de música española del siglo XVII conservado en la Bayerische Staatsbibliothek de Munich (signatura Mus. Mss. 2902) ${ }^{48}$.

\section{Rematados por una corona ${ }^{49}$ :}

2.1. con el círculo superior en blanco: filigranas 17 (E: Zac, B-3/48), y 18 (B-13/237).

2.2. con una cruz en el círculo superior: [filigranas similares a las de Oriol Valls números 3 (Toledo, 1604) y $\mathrm{N}^{\circ} 9$ (Sevilla, 1650; proc. de la Catedral de Toledo), ambas de origen francés]: filigranas 19, 20, 21 y 22 (E: Zac, B-3/40), 23 (B-3/44), 24 (B-3/46), 25, 26, 27 y 28 (B13/235), 29 (B-13/240; copia musical del año 1647), 30 y 31 (B-13/241), 32 (B-13/242), 33, 34 y 35 (B-32/520). Conocemos también otra variante procedente de El Escorial, signatura E 83$7 / 2^{50}$, y tres ejemplos recogidos por mí en la muniquesa Biblioteca de Baviera ${ }^{51}$.

46. Nótese que esta filigrana aparece en sus diversas variantes como de origen francés en Toledo, en 1601; en Zaragoza, en 1639, y como de origen genovés en Cáceres y Madrid, en el siglo XVIII. (El hecho de que un siglo más tarde a su aparición en España procedente de Francia, se siguiera utilizando esta misma filigrana - variantes - en Italia, y se exportase a tierras españolas, parece un síntoma bastante claro de que no sólo los papeleros españoles copiaban a los extranjeros, sino que éstos se copiaban entre sí - en este caso concreto, italianos a franceses - , y, tal vez, también a los españoles - los genoveses a los españoles-).

47. -P. R. Laird: op. cit., -vid. nota 9- p. 214 [Watermark Type B], y p. 218 [Watermark Type F, sign. E 28-8]. Aquí mismo (p. 216), inserta otro ejemplo escurialense del tipo tres círculos rematados por cruz latina, con letra en el círculo superior [Watermark Type D, sign. E 6-9/1].

48. Vid. anexo, filigrana $\mathrm{n}^{\circ} 85$. Se encuentra en una composición musical del maestro Miziezes.

49. -W. A. Churchill: op. cit., - - vid. nota 37-. Según la descripción de este autor, este tipo de filigrana (dibujos 551, 559 y 560) aparecida con frecuencia en fuentes españolas, dependería de las fuentes italianas (aunque es posible que fuera producido también en España). En cualquier caso, existen grandes similitudes entre las marcas de agua genovesas y las halladas en España, siendo todas del mismo período. Más aún, Churchill adscribe su filigrana número 551 al taller genovés del papelero Giacomo Gambino. Sin embargo, las referencias extraídas de Churchill despistan un poco, pues todos sus ejemplos difieren en la práctica de los ejemplos zaragozanos: es decir, son útiles en cuanto a la familia y el tipo, pero divergen notablemente en cuanto a las variantes.

50. -P. R. Laird: op. cit., —vid. nota 9- p. 215 [Watermark Type C].

51. Vid. anexo, marcas de agua números 86,87 y 88 , correspondientes a las signaturas de dicha biblioteca Mus. Mss. 2910 (composición musical de Fray Dionisio Romero), Mus. Mss. 2887 (obra del maestro Cristóbal Galán) y Mus. Mss. 2895 (obra de Juan Hidalgo), respectivamente.

\section{2}

(c) Consejo Superior de Investigaciones Científicas Licencia Creative Commons

Reconocimiento 4.0 Internacional (CC BY 4.0)
Anuario Musical, 55 (2000)

http://anuariomusical.revistas.csic.es 
2.3. con media luna en el círculo superior: [marcas de agua similares a las reflejadas por Briquet $^{52}$ :] filigranas 36, 37 (E: Zac, B-3/43), 38 (B-3/45), 39, 40 y 41 (B-13/234), 42 (B13/237), 43 (B-13/238), 44 (B-13/240; copia musical del año 1647), 45 (B-32/509; copia musi-

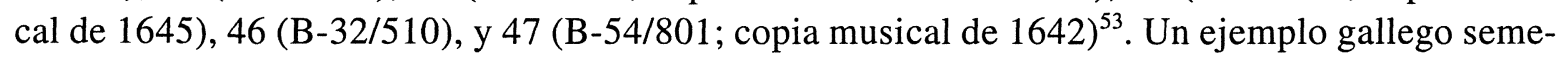
jante a los números 42 y 44 de Zaragoza, lo hallamos en un volumen titualdo "Descripción del Reyno de Galicia", de hacia finales del siglo XVII, cuya marca de agua se copia en: -José Luis Basanta, coord.: "Antonio Odriozola y las marcas de agua", en El Museo de Pontevedra,XLIV, 1990, pp. 127-149 [cfr. especialmente página 133].

3. Otros: filigranas 48 (E: Zac, B-13/236), 49 (B-3/40), 50, 51, 52, 53 у 54 (B-3/40).

- Por su parte, la marca de agua que representa una "cruz" (filigranas números 55 al 70), dentro de un marco con forma de lágrima o corazón, se halla extendida por todo el ámbito mediterráneo (sur de Francia, Italia peninsular, Sicilia y España). Éstas son las recogidas en el archivo de Zaragoza: Cruz:

1. con remate superior de corona e inferior de letras colgantes ${ }^{54}$ : filigranas 55 (E: Zac, B-3/39), 56 (B-3/41), 57 (B-13/244), y sin letras colgantes, filigrana 58 (E: Zac, B-3/45)

2. con remate inferior de letras colgantes: filigranas 59 (E: Zac, B-3/39) [Briquet $\mathrm{N}^{\circ} 5703$ (Carcasona, 1592), y № 5704 (Perpiñán, 1595)]; 60 (E: Zac, B-66/945; copia musical del año 1629), 61 (B-32/516; copia musical de 1633) [Briquet No 5680 (Siracusa, 1582)]; y 62 (E: Zac, B32/519; copia musical de 1633) [Briquet $N^{\circ} 5703$ (Carcasona, 1592), No 5704 (Perpiñán, 1595), No 5680 (Siracusa, 1582), № 5684 (Mantua, 1555), № 5688 (Perpiñán, 1596)]. Para las filigranas zaragozanas $\mathrm{n}^{\circ} 56$ y 62 , pueden verse algunas similitudes en otro trabajo: $c f r$. los números 83 y 80 respectivamente (datados a su vez en 1625 y 1586) del trabajo de $\mathrm{M}^{\mathrm{a}}$ Rosario Valenzuela

52. -C. M. Briquet: op. cit., —vid. nota 35-. [Cfr. sus filigranas números 238 y 239]. Según Briquet (p. 83), estas marcas de agua se encuentran en España durante el siglo XVII, en documentos de las cancillerías españolas en Madrid y Bruselas entre 1607 y 1670. Sin embargo, Briquet habla en términos amplios, sin aclarar más su procedencia.

53. El hecho de que aparezcan variantes de esta filigrana en distintas copias musicales zaragozanas de los años 1642 (una composición del maestro Pedro Martínez Vélez), 1645 (una obra de Mateo Virto), y 1647 (obra de Urbán de Vargas), puede ser muy significativo: 1) es evidente que esta marca de agua era de uso muy frecuente en tierras aragonesas; 2) a falta de actas capitulares del Pilar del siglo XVII anteriores a 1645, podemos deducir lo siguiente: en vista de que Vargas fue maestro del Pilar desde finales de 1645 hasta 1651 y más tarde de nuevo en 1653, parece claro que fuera el maestro de capilla de la iglesia quien escribiera en 1647 una composición para ser interpretada ahí; ¿podríamos deducir lo mismo de las otras dos composiciones? Tal vez sí. Tanto de Virto como de Martínez Vélez se conservan varias obras en el archivo, y sabemos que ocuparon importantes capillas en fechas anteriores o posteriores a las indicadas en estas obras. En cualquier caso, sabemos de Virto que pocos años antes había sido maestro de capilla de la Catedral de Tarazona, y Martínez Vélez de la seo de Calahorra, ambos lugares relativamente cercanos a Zaragoza y en estrecha relación con su cabildo, por lo que tal vez llegaran estas obras al archivo zaragozano respondiendo al intercambio habitual de obras en la época entre los maestros de capilla, en este caso, los de los lugares indicados. Por otra parte, la filigrana número 571 de la obra ya citada de W. A. Churchill, que data del año 1786 y procede de Génova, es muy similar a una filigrana recogida por P. R. Laird en su tesis (El Escorial, sign. E-95-8), correspondiente esta última a un villancico del maestro Vargas, que habría sido re-copiado a finales del siglo XVIII; todo ello es indicio de que las mismas filigranas habituales en la península se repiten, con las lógicas variantes, a lo largo de todo el territorio nacional y se prolongan en el tiempo durante más de un siglo, lo que responde a una costumbre o tradición que se iba enraizando entre los maestros papeleros hispanos (quienes a su vez habrían comenzado a utilizar estas marcas imitando a franceses e italianos). De otro lado, ahí queda apuntada también la posibilidad de que esta filigrana, muy posiblemente de origen genovés, hubiera pasado a España (El Escorial, Zaragoza).

54. Para este apartado, véase también Oriol Valls i Subirà, vol. III, filigranas de origen francés, número 18 (Gerona, 1630).

55. Vid. ejemplos gallegos algo semejantes en: -José Luis Basanta, coord.: “Antonio Odriozola y las marcas de agua”, en El Museo de Pontevedra,XLIV, 1990, pp.127-149 [cfr. especialmente página 132]. 
("Filigranas en el Archivo Histórico Provincial de Teruel", en Teruel, LXXXV/2, 1997, pp. 5998 -página 80-). [Véase también Oriol Valls i Subirà, vol. III, filigranas de origen francés, $\mathrm{N}^{\circ}$ 2 (Toledo, 1603), $\mathrm{N}^{\circ} 6$ (Toledo, 1615), № 15 (Alcalá de Henares, 1617), No 16 (Sevilla, 1623), y No 17 (Madrid, 1627). Y Oriol Valls, vol. II, p. 198: filigranas $\mathrm{N}^{\circ} 83$ (Toledo, 1533), $\mathrm{N}^{\circ} 97$ (Valencia, 1596), № 98 (Valencia, 1597), y № 99 (Córdoba, 1600)] ${ }^{56}$.

3. con remate superior de gancho e inferior de letras colgantes: filigranas 63 (E: Zac, B-32/517; copia musical del año 1633), 64 y 65 (B-32/518; copia musical de 1634), y 66 (B-75/1108; copia musical de 1633). Existe un ejemplo de esta variante en El Escorial, sign. E 65-7 ${ }^{57}$.

4. Otros: filigranas 67 (E: Zac, B-3/48), 68 (B-32/515), 69 (B-32/515; copia musical del año 1632), y 70 (B-62/887; copia musical de 1639) [similar en Játiva, filigrana $\mathrm{N}^{\circ} 57$ — sin letras colgantes-, que data de los años 1418 y 1478].

- Las filigranas números 71 al 75, correspondientes a la familia "escudo", de la cual Briquet ofrece numerosos ejemplos, no tienen ningún ejemplar siquiera similar entre los catálogos consultados. Son las filigranas 71, 72 y 73 (E: Zac, B-13/239; copia musical del año 1645), 74 (B13/244), y 75 (B-64/907; copia musical de 1644). No obstante, las números 71 a 74 podrían sugerirnos una posible procedencia de la corte madrileña (?), habida cuenta de que muestran el águila imperial coronada, propia de los Habsburgo, y que por esas fechas Felipe IV estuvo en Zaragoza. De la filigrana $n^{\circ} 73$ tenemos un ejemplo muy lejanamente similar en el volumen titulado "Descripción del Reyno de Galicia", de hacia finales del siglo XVII, cuya marca de agua se copia en: -José Luis Basanta, coord.: "Antonio Odriozola y las marcas de agua", en El Museo de Pontevedra, XLIV, 1990, pp. 127-149 [cfr. especialmente página 133]. También en la filigrana 85 de nuestro anexo (Biblioteca de Baviera, Munich, signatura Mus. Mss. 2902, estampada en una obra del maestro Miziezes), existe una marca de agua del tipo tres círculos con el águila imperial coronada en su círculo central, lo que también apunta en la dirección de una posible procedencia de la corte. No obstante, esta suposición tampoco queda despejada, puesto que Paul R. Laird parece demostrar que "ninguna filigrana era reservada exclusivamente para el uso real"58.

56. Este tipo de filigrana presenta pues unos antecedentes italianos de la segunda mitad del siglo XVI (Mantua 1555, Siracusa 1582), pasando de ahí - en sus variantes - al sur de Francia (Carcasona 1592, Perpiñán 1595 y 1596), hasta aparecer en Zaragoza en copias musicales de los años 1629 y 1633, cubriendo así un circuito geográfico y temporal bastante probable, con un lapso de 37 años entre la primera aparición en Italia y la primera en Francia, y otros 37 años entre la primera aparición en Francia y la primera en Zaragoza. Entretanto, y como de origen francés, Oriol Valls cita ejemplos conservados en España que van desde 1533 hasta 1627, apuntando, por su antigüiedad, su posible origen español. A este respecto señala (op. cit., vol. II, pp. 128-129) que "esta filigrana es muy abundante en España y se encuentra esparcida por toda ella. [...] Briquet nos dice que el papel con esta marca podría ser oriundo de Francia (así genéricamente), o de Génova, según el tipo de letras que a veces acompañan a la filigrana. [...] De veinticinco que presenta (filigranas núms. 5677 a 5704 , dos son procedentes de España, sin precisar, y cuatro de Madrid. Esto sin incluir las que se encuentran en Perpiñán, Tolosa de Languedoc y Carcasona, cuya influencia de la Corona de Aragón era grande".

57. -P. R. Laird: op. cit., -vid. nota 9- p. 593.

58. -P. R. Laird: op. cit., p. 230 . Este autor, que ha trabajado diversos archivos y bibliotecas relacionados estrechamente con la Corte (El Escorial, Simancas, Catedral de Valladolid, Biblioteca Nacional), entre los que ha encontrado interesantes similitudes en sus filigranas, señala además una amplia dispersión por toda España de las marcas por él recogidas, lo que le lleva a concluir que [la traducción es mía] "los manufactureros de papel que suministraron este papel al Escorial estaban entre los principales -mayores- proveedores de papel de la península ibérica". No obstante su acertada teoría, considero que la conclusión no guarda relación con su planteamiento, y que tal afirmación no podrá confirmarse en tanto en cuanto no existan más trabajos al respecto sobre las fuentes españolas. 
- La marca de agua número 76 (signatura $E$ : Zac, B-3/35), correspondiente a la familia "esfera", cuenta con dos parientes lejanos (Briquet $\mathrm{N}^{\circ} 14036$ y No 14037) que datan ambos del año 1590 y proceden de la ciudad francesa de Angulema. Por tratarse de una obra musical del maestro Vargas, su fecha de copia habrá que fijarla entre 1645 — fecha de su llegada a Zaragoza - y 1656 fecha de su muerte-.

- También de las familias "letra", filigrana número 77 ( $E$ : Zac, B-3/47), y "letras entrelazadas", filigranas números 78 a 81 , Briquet ofrece varios ejemplos. Las marcas de letras entrelazadas llevan los números 78 (E: Zac, B-3/46), 79 y 80 (B-3/49), y 81 (B-66/950; copia musical del año 1657). He localizado una variante de la número 79 en Briquet $N^{\circ} 9547$, procedente de Venecia, con una datación del año 1471. También Paul R. Laird ofrece varias muestras de letra y letras entrelazadas procedentes de El Escorial (sign. E 139-4/5, E 32-17, E 33-4, E 70-6, E 139-4/2, etc.), y D. García Fraile, de Salamanca, aunque difieren de las zaragozanas. Lo mismo sucede con las que proceden de la Bayerische Staatsbibliothek de Munich ${ }^{59}$.

- La filigrana número 82 (signatura $E$ : Zac, B-13/244), corresponde a la familia "mano", que ha sido estudiada particularmente por el profesor Orduna ${ }^{60}$. Esta familia se halla muy repartida por toda Europa, y existen numerosos ejemplos similares - si bien ninguno idéntico al zaragozano- en Francia [Briquet $\mathrm{N}^{\circ} 10818$ (Limoges, 1599), No 11176 (Arras, 1543), No 11284 (Perpiñán, 1572), y variantes del grupo $\mathrm{N}^{\circ} 11174$ a 11176 (Nantes, 1527; Ruán, 1527; Perpiñán, 1542; y Carcasona, 1543)], Italia [Briquet $N^{\circ} 10717$ (Venecia, 1498)], y España [Oriol Valls i Subirà No 4 y 4 bis (Valladolid, 1613); Mosqueruela No 251 (Cedrillas, 1488); y Gemma Avenoza-Germán Orduna (1990), № 33a (Arxiu del Palau Recasens, actualmente en el Casal Borja, de Sant Cugat del Vallès, Barcelona]. En Játiva ( $N^{\circ} 85$ al 117) y Mosqueruela ( ${ }^{\circ} 218$ a 283 y 357 a 358), existen otras muchas derivaciones, incluso con la flor sobre el dedo corazón, pero no resultan lo suficientemente parecidas a la nuestra como para indicarlas aquí ${ }^{61}$. Curiosa resulta también, aunque con escasas semejanzas a la zaragozana, la filigrana $\mathrm{n}^{\circ} 33 \mathrm{~b}$-mano enguantada con flor de seis pétalos-que recogen Avenoza y Orduna (1990), perteneciente al Cancionero General de Hernando del Castillo (Valencia, 1511).

59. Véase anexo, filigranas números 89 y 90, ambas correspondientes a la signatura Mus. Mss. 2899 de dicha biblioteca germana (aparecen en una obra musical de Juan Hidalgo), y notas a pie de página $n^{\circ} 6$ y 9.

60. -Germán Orduna: "Registro de filigranas de papel en códices españoles", en Incipit, VII. Buenos Aires, Seminario de Edición y Crítica Textual. Consejo Nacional de Investigaciones Científicas y Técnicas de la Argentina, 1987, pp. 1-6; [recoge 11 filigranas distintas]: "El tema (familia) «mano enguantada con flor o estrella». Es tema digno de una futura recōlección amplia y sistemática dada su prolongada permanencia en el tiempo (desde fines del siglo XV hasta fines del XVI) y su difusión en códices librarios, primeros impresos y papeles de notario de la zona de Burgos. El tema aparece también en marcas de papel utilizado en Francia (vid. Briquet), lo que puede avalar la procedencia francesa de parte de la materia escriptoria revisada. [...] persistencia del diseño por más de un siglo".

61. Lo mismo sucede con los siguientes artículos, dos valencianos y uno gallego; en el primero, se insertan hasta cuatro ejemplos de mano enguantada con flor, aunque disímiles a la nuestra del archivo zaragozano: -Josep Cortès: "El paper i les filigranes", en La impremta valenciana. Valencia, Generalitat Valenciana, 1990, pp.143-154 [cfr. especialmente pp.148 y 149]. El segundo caso (José Sánchez Real y Jesús E. Hernández Sanchis: "Las filigranas medievales del Archivo Municipal de Alzira", en AlGezira, VI, 1990, pp.184 y 185), recoge también algunos ejemplos de manos enguantadas, siendo la más cercana a la zaragozana la ${ }^{\circ} 341$ (datada en el año 1399). En el tercer caso, gallego, se ofrecen abundantes ejemplos de manos enguantadas con flor: -José Luis Basanta, coord.: "Antonio Odriozola y las marcas de agua", en El Museo de Pontevedra,XLIV, 1990, pp.127-149. [vid. especialmente las filigranas procedentes de un Breviario auriense del año 1485 procedente de la Catedral de Orense y de un Manual auriense impreso en 1510]. 
- Por último, quedan totalmente incógnitas otras marcas de agua -familia "indeterminado"-: filigranas números 83 y 84 . Ni de la número 83 ( $E:$ Zac, B-3/37), que aparece en la partichela del acompañamiento continuo, ni de la número 84 ( $E$ : Zac, B-13/239; copia musical del año 1645), he conseguido hallar referencia alguna.

- Asimismo, existen algunas composiciones musicales revisadas en las que no aparece ninguna filigrana ( $E$ : Zac, B-3/36, B-3/38 y B-13/243), casi con seguridad debido a que los pliegos originales de papel (de una medida cercana a nuestro actual DIN A-3) se cortaban a menudo para su mejor uso y aprovechamiento en mitades, habiéndose utilizado en estos casos las mitades no portadoras de la marca de agua $^{62}$.

\section{Conclusiones a partir del fondo estudiado:}

En todos los casos, a falta de estudios en profundidad sobre el tema, se haría necesario descifrar si fue la filigrana extranjera la que sirvió de modelo a la conservada en Zaragoza, o viceversa, si bien todo parece indicar, visto el tema en su conjunto, que, al menos, el modelo originario de cada familia, habría llegado a España desde Francia o Italia en el siglo XVI, siendo imitado, modificado, o reproducido con variantes, en los molinos papeleros españoles a partir del siglo XVII.

De hecho, de entre todas las filigranas zaragozanas que he recogido, casi todas las identificadas o aquellas a las que he hallado parientes similares o cercanos, aparecen con un primer origen francés o italiano del siglo XVI. Pero no obstante (apenas conocemos la industria papelera española de la época, y recordemos que tratamos de música de la primera mitad del siglo XVII), habrá que tomar esta afirmación con las debidas precauciones.

Sí que resulta bastante claro, y así todo lo parece indicar, que tales modelos foráneos del siglo XVI habrían llegado a España más tardíamente. De este modo, podemos observar a comienzos del siglo XVII algunos ejemplos de filigranas similares a las zaragozanas — supuestamente imitadoras de modelos extranjeros anteriores-, que proceden de distintos lugares de la península ibérica. Parece relativamente claro que se trataría en muchos casos de papel extranjero, muy probablemente salido del molino papelero en que se fabricó, cuarenta o cincuenta años antes de que se copiara en él su contenido musical. Pero es preciso insistir en mantener una lógica cautela: las conclusiones extraídas del manejo de este material, siempre deberán apoyarse, para obtener una correcta datación de los papeles, de otros múltiples factores, tales como el tipo de caligrafía, la notación musical empleada, la calidad o tipo de la tinta, etc. etc.

62. En otros casos, el papel se doblaba en un pliego, de suerte que la música podía anotarse en ambos lados del pliego resultante (algo parecido a dos DIN A-4 unidos por un pliegue), aunque generalmente únicamente se escribía por su cara externa (y no por su cara interna); otras veces, únicamente se utilizaría una cara para escribir — de las cuatro posibles a utilizar-, y ha sido precisamente en una de las caras en blanco, en donde, por fortuna, se nos ha conservado la marca de agua. En este mismo sentido, también en el estudio citado de Laird llevan marca de agua todas las composiciones trabajadas, excepto dos. Laird no soluciona la carencia de filigranas en estas dos obras, limitándose a apuntar que la explicación que parecería más lógica no resulta verosímil (que se tratara de mitades perdidas de folios), ya que cada uno de estos dos villancicos tiene sus partes copiadas en folios plegados. [¿Cabría pensar aquí en tamaños originalmente mayores al de dichos pliegos?]. 
Por otra parte, tras el estudio realizado, coincido plenamente con la conclusión obtenida por Paul R. Laird de que "mientras es difícil imaginar que la identificación de una marca de agua pueda ser lo suficientemente específica como para ligar una filigrana a un compositor particular, las reproducciones demuestran para nuestros propósitos que al menos alguna de las filigranas del Escorial [y en nuestro caso, de Zaragoza] se encuentran en otros archivos españoles"63.

El análisis de las 42 composiciones "a papeles" trabajadas específicamente en este trabajo (lo que supone exactamente 400 papeles de música revisados en total), ha ofrecido tres composiciones musicales sin filigrana alguna. Del total de obras estudiadas, 26 composiciones estaban sin datar (siendo todas ellas atribuibles - por otras razones - al reinado de Felipe IV, 1621-1665), mientras que 16 composiciones (el 38\% del total revisado) llevaban fechas comprendidas entre el año 1629 y 1645.

El estudio de las 84 filigranas distintas escogidas de entre sus papeles, nos ha revelado una clara preponderancia numérica de dos únicas familias de marcas de agua (círculo —en su tipo tres círculos-, y cruz), sumando ambas más del $83 \%$ del total de marcas de agua recogidas en el archivo zaragozano. De estas filigranas, 54 corresponden a la familia círculo (algo más de un $64 \%$ respecto del total), y 16 a la familia cruz (19\%), mientras que tan sólo aparecen 5 marcas de agua de las familias escudo y letra/letras entrelazadas (casi un 6\% para cada familia). Por último, el resto de familias encontradas son meramente testimoniales: 2 filigranas de la familia indeterminado (2'38\%), y 1 de las familias esfera y mano, respectivamente (1'19\% cada una).

En cuanto a las fechas en que aparece con mayor frecuencia cada familia de marcas de agua es claramente apreciable un cambio en los gustos -y presumiblemente, también en los proveedores de papel-, pues se constata una clara tendencia en la década de los años 30 del siglo XVII (concretamente, en los años 1629, 1632, 1633, 1634 y 1639) a utilizar en Zaragoza papel con marca de agua de la familia cruz, grupo entonces predominante en el archivo estudiado, para pasar a ser anulada dicha preferencia en los años 40 (concretamente en 1639, 1642, 1645 y 1647) por la familia círculo - en su tipo tres círculos-, filigrana que aparece en un porcentaje todavía mayor.

Las procedencias apuntadas para las marcas recogidas en el Archivo de Música de las Catedrales de Zaragoza son similares a lo largo de la primera mitad del siglo XVII: en general, se reducen al ámbito mediterráneo, concretándose en la denominada media luna o arco mediterráneo que nace en Venecia, pasando por Milán, Marsella, Perpiñán y Barcelona -ensanchando su diámetro hasta el centro peninsular-, hasta llegar a Valencia. Abarca pues la Italia continental e insular, la Francia mediterránea y del Sur, y la España del círculo cortesano (Madrid, Toledo, Alcalá, El Escorial, Valladolid), amén de algunas importantes ciudades aisladas como Valencia, Sevilla o la propia Zaragoza.

En la década que va desde 1630 a 1640, parece predominar en la capital del Ebro el papel procedente del sur de Francia (Carcasona, Perpiñán, Toulouse), junto al italiano (sobre todo genovés, aunque también podría venir de Mantua o Siracusa), y español (del área de la Corte,

63. -Paul Robert Laird: op. cit, - vid. nota 9-. Cfr. p. 225. 
levantina — Valencia, Játiva—, andaluza — Sevilla, Córdoba—, o de la propia Corona de Aragón -Zaragoza, Gerona-).

Entre 1640 y 1650 sin embargo, los lugares de origen del papel parecen reducirse un poco, sobresaliendo por encima del resto el papel francés (Perpiñán) y el genovés (aunque también podría haberse adquirido papel de otros lugares de Italia tales como el Milanesado - Milán y su entorno, o Mantua); un tercer origen más que probable apunta hacia las cortes de los Austrias en Madrid (Toledo, El Escorial) y Bruselas; por último, tal vez llegara alguna partida procedente de diversos lugares del norte de la península (incluída Zaragoza), y en menor cantidad, del Sur y Andalucía (Sevilla, Cáceres), mientras que resulta ya mucho más escaso el papel de Valencia o Cataluña.

De diversos años, encontramos algunos papeles aislados — sus filigranas infrecuentes así lo demuestran- que denotan las más variadas procedencias, tales como las localidades francesas de Angulema, Limoges, Arras, Nantes, o Ruán, la italiana de Venecia, u otras muchas del territorio peninsular. Curiosamente, aparte de algún ejemplo de Bruselas, no se ha podido localizar siquiera un solo ejemplo publicado procedente de Portugal (donde el estado de los estudios sobre el tema debe encontrarse en una situación similar a la española), ni de países tan importantes en la producción papelera como Inglaterra o Alemania.

No obstante, en el proceso de investigación de manuscritos musicales en las catedrales de Zaragoza, he podido establecer que muchas de las filigranas de Zaragoza se encuentran también en otras fuentes del siglo XVII en papel, hallando variantes no sólo en la península, sino incluso en lugares tan lejanos como la alemana Bayerische Staatsbibliothek de Munich (para los ejemplos zaragozanos del tipo tres círculos, véanse las filigranas muniquesas que he cifrado aquí -en un anexo- con los números 85 al 88, y para las marcas de agua de las familias letra y letras entrelazadas, véanse los dibujos 89 y 90 procedentes de la mencionada biblioteca bávara) ${ }^{64}$.

En conjunto, y por comparación con otros papeles musicales de la misma época analizados en otros archivos españoles y extranjeros, los papeles en que se copiaron las composiciones

64. He dejado aparte las marcas de agua citadas por tratarse obviamente de un fondo diferente al de las catedrales zaragozanas. De las composiciones "a papeles" españolas el siglo XVII conservadas en la Bayerische Staatsbibliothek de Munich, recojo no obstante aquí, en anexo aparte, aquellas que por su similitud con las halladas en Zaragoza resultan de interés para este trabajo concreto. El fondo de música española "a papeles" de la mencionada biblioteca supone dos colecciones: una, con piezas manuscritas originales del siglo XVII, que parecen proceder - por sus autores- del círculo de la Corte madrileña (67 obras, menos una, perdida); dos, una serie de transcripciones en partitura de obras hispanas de los siglos XVII y XVIII, y de procedencia catalana, copiadas por el coleccionista de música (también trompetista y compositor) Anton Andrelang (26 obras). En conjunto, estas 92 obras denotan una excelente calidad musical. De este rico fondo, que ha sido catalogado y trabajado minuciosamente por la Dra. Gertraut Haberkamp, incluso se llegó a radiar públicamente, en la Bayerischer Rundfunk München, dentro de la Serie "Musik aus dem alten Spanien" (Archiv-Nr.61/00.015), los días 27 de Marzo al 24 de Abril de 1963 la interpretación de varios villancicos del primer fondo mencionado (en transcripciones de G. Haberkamp): obras de Cristóbal Galán, Juan Romero, Fray Domingo Ortiz de Zárate y otros. Para más información al respecto pueden consultarse los siguientes artículos, así como la tesis doctoral sobre el primer fondo, realizada por Bernat Cabero (Der Villancico des XVI. und XVII. Jahrhunderts in Spanien. Berlín, dissetation.de, 2000): -Julius Joseph Maier: "Die Musikalischen Handschriften der K. Hof-und Staatsbibliothek in Muenchen. Erster Theil. Die Handschriften bis zum ende des XVII. Jahrhunderts", en Catalogus Codicum manu scriptorum Bibliotheca Regia Monacensis. Tomi VIII Pars I. Codices Musicos usque ad finem saculi XVII complectens. Munich, Libraria Regia Palmiana (in commission der Palm'schen Hofbuchhandlung), 1879. -Erich Tremmel: "Anton Andrelang-Trompeter, Komponist und Musiksammler. Beiträge zur Musikgeschichte am königlich bayerischen Hof, zur Rezeption neuer Blasinstrumententypen sowie zu einem Bestand spanischer Musik der Renaissance und des Barock in Bayern", en Augsburger Jahrbuch für Musikwissenschaft 1987 (Franz Krautwurst, ed.), Tutzing, Hans Schneider, 1987, pp. 193-210. 
musicales de las catedrales zaragozanas no denotan una excesiva buena ni mala calidad "física", sino que se corresponden con los demás; es decir, podemos decir que cumplen con el modelo estándar de papel para copia musical —son por tanto representativos- de su tiempo. También podría pensarse en una datación documental atendiendo a la calidad del papel a estudiar (más o menos poroso, con fibras más o menos visibles al trasluz, etc.), pero ello nos llevaría a tener que conocer ampliamente la producción papelera salida de cada molino, la localización de éstos, y otro largo etcétera, que hacen hoy por hoy inviable este procedimiento. No obstante, puedo adelantar a grandes rasgos que a mediados del siglo XVII en Zaragoza predomina un papel de relativa buena calidad, más bien fino, que deja ver las vetas de sus fibras si se mira al trasluz (recuerda al papel de China); para hacernos una idea más aproximada, podemos pensar en un papel algo más grueso que el conocido actualmente como "papel de seda" utilizado para envolver pequeña paquetería. Es pues un papel que no se rompe fácilmente, pero que, cuando recibe una cantidad grande de tinta en el mismo lugar (piénsese en el ennegrecimiento de las cabezas de las notas musicales), resulta fácil de traspasar. En general, este es el papel más común, pero también podemos encontrar ejemplos de papeles más gruesos y bastos, incluso rugosos, similares a un cartón fino o cartulina, o al papel de filtro (como p.ej. en $E$ : Zac, B-3/46, 3/47, etc.). A la hora de la copia del documento musical, predomina el denominado "papel pautado a la italiana" (es decir, en formato apaisado, lo que es más común, sobre todo, en los villancicos y otras piezas en lengua romance, a su vez más numerosas en esta época que las piezas litúrgicas entre el repertorio conservado), sobre el "papel pautado a la francesa" (de formato vertical, más propio de las piezas litúrgicas en latín).

Una conclusión deducible del hecho de que algunas de estas marcas de agua, y por tanto el papel en que están impresas, pueda proceder con un alto grado de fiabilidad de lugares tan lejanos a Zaragoza como Génova, Mantua, Venecia, Bruselas o Carcasona, sólo por citar algunos ejemplos, demuestra que la sociedad zaragozana en general y sus dos cabildos catedralicios en particular, era mucho más abierta a lo foráneo de lo que "a priori" se pudiera pensar. Se trataría de modo habitual (el suministro necesario de papel para la administración cotidiana catedralicia así lo obligaría) con proveedores extranjeros o locales aunque especialistas en la importación de determinadas materias primas $^{65}$. De esta forma, el cabildo se debía mover en unos circuitos que superaban en ocasiones las fronteras nacionales, como así lo viene a demostrar no sólo el hecho de que se comprara papel fuera de la península, sino que también hubo un importante intercambio de músicos y de composiciones.

La procedencia del papel que hemos rastreado a través de sus marcas de agua se corresponde, "grosso modo", con la de los compositores extranjeros reflejados con sus obras en el Archivo de Música de las Catedrales de Zaragoza. Se trata sobre todo de composiciones de ámbito mediterráneo, donde de alguna manera tenía presencia la corona española, es decir, se trata fundamentalmete de obras italianas (sobre todo del área vaticana y napolitana, aunque también las hay del norte), unas cuantas francesas, e incluso numerosos ejemplos de compositores flamencos, frente a una ausencia casi total de músicos del área anglosajona o germana.

65. Téngase presente de nuevo la presencia en la capital zaragozana de numerosos mercaderes de procedencia francesa, muchos de los cuales se dedicaban al comercio de libros con el país vecino. 
Estas obras, las más significativas de la época, debían contrastar no obstante con el fuerte localismo de las composiciones de cada momento: la tónica predominante, no era pues la del intercambio internacional, sino la del intercambio nacional, habiendo, eso sí, una gran movilidad de autores y obras por toda la península. Así nos lo indica la documentación (tradicionalmente, se ponen edictos a oposiciones en lugares cercanos a Zaragoza, se manda traer músicos de fuera para cubrir las necesidades de las capillas, se compran instrumentos en otros lugares, etc. etc.).

En definitiva, es preciso ver que ni Zaragoza era ya un centro de actividad puntero a nivel europeo en la época, ni tampoco era un centro "local”, provinciano, encerrado en sí mismo. Más bien tendríamos que situar nuestra evaluación en su justo lugar, dentro de lo que Zaragoza significaba en España, de lo que España significaba entonces en el concierto europeo, y dentro de lo que la música española representaba a nivel internacional respecto a la de otras naciones avanzadas. Es decir, al igual que toda España, que había perdido la preponderancia adquirida bajo el imperio de los llamados Austrias mayores, Zaragoza también perdió con los Austrias menores el esplendor de épocas pasadas, aunque, frente a ello, siguió aportando su grano de arena a la corona española en decadencia, en un tiempo en el que las letras y las artes alcanzaban su apogeo, su Edad de Oro. En este sentido, el papel de Zaragoza a nivel musical continuó siendo uno de los más destacados de la península (no olvidemos que es la única ciudad de España — hay quien afirma que del mundo- que cuenta con dos catedrales - y por tanto, con dos importantes capillas musicales en activo-, las cuales por cierto unirían sus cabildos en el año 1675), como cabecera de la Corona de Aragón, a pesar de que a nivel internacional, como el resto del país, comenzara a contar poco. Pero la gran riqueza de músicos, instrumentos, composiciones conservadas de la época (estamos ante el mayor archivo musical catedralicio hispano), y un largo etcétera, nos llevan a tener que replantearnos muchas cuestiones que hasta ahora se daban por zanjadas al haberse reducido al terreno de los tópicos. Quién sabe, si, a falta de más estudios, la música en Zaragoza, y en Aragón, contó realmente más de lo que imaginamos.

\section{Reflexión final:}

Hasta aquí, a propósito de la recogida de marcas de agua como método de trabajo de interés para la Musicología histórica, he procurado ofrecer un panorama de la cuestión en nuestro país, concretado en un caso concreto, el zaragozano, y centrado en un período de tiempo asimismo concreto y reducido. Obviamente, la importancia del caso hay que verla en su contexto: se trata tan sólo de un ejemplo entre los múltiples posibles, aunque, quién sabe, si, tal vez, pueda servir como caso paradigmático de lo que nos podamos encontrar en otros archivos y bibliotecas de música españoles. Y éso, probablemente, sólo el tiempo y otros trabajos en este sentido lo podrán dilucidar.

Lo que sí intenta este trabajo es ser acicate para nuevos y mejores trabajos en esta línea, y para contribuir a la mayor difusión posible entre los profesionales con vistas a la recogida de filigranas. En tanto en cuanto no seamos muchos quienes nos dediquemos a recoger las marcas 
de agua de nuestros papeles de música, no nos será posible comparar, y por tanto, identificar, y aun datar, muchos materiales documentales, de los que, de otro modo, no dispongamos apenas de pistas al respecto.

En este sentido, este trabajo quiere ser también una llamada de atención a los responsables de nuestros archivos y bibliotecas de música, que, en ocasiones, llevados por un encomiable celo documental, no permiten a los investigadores la recogida de tales de marcas de agua por miedo a que se puedan dañar los originales. Si, en algunas bibliotecas del extranjero (como la mencionada y modélica Bayerische Staatsbibliothek de Munich tan citada en este trabajo), no sólo se dispone de lectores de marcas de agua, sino que (obviamente bajo la atenta mirada del bibliotecario que resguarde la integridad documental) se anima al investigador a recoger tales datos, lamentablemente, en nuestro país, todavía muchas de nuestras grandes bibliotecas ni siquiera contemplan tal posibilidad, con el consiguiente perjuicio y menoscabo para nuestra investigación. Esperemos que, en beneficio del avance científico en nuestra disciplina, y con la ayuda de nuestros bibliotecarios y archiveros, se pueda conjugar la "seguridad" documental con el estudio, y que nuestras bibliotecas y archivos musicales permitan, cada vez más, y con las mayores garantías, recoger marcas de agua.

En otro orden de cosas, naturalmente, la recogida de filigranas deberá hacerse con el imprescindible papel vegetal, y siempre a lápiz, calcando directamente del original, y obviamente sin presionar sobre él. Como queda patente después de los análisis en que nos hemos centrado, en cuanto a variantes y diferentes procedencias y dataciones entre marcas de agua similares aunque no iguales, no son de utilidad alguna las marcas de agua tomadas "a mano alzada" (antes al contrario, pueden inducir a graves errores de apreciación).

En definitiva, y resumiendo, desde mi experiencia concreta, mi opinión es que la recogida de marcas de agua como material para determinar la datación y procedencia de nuestras fuentes documentales histórico-musicales es un método, al día de hoy, poco "fiable" en sí mismo ${ }^{66}$, puesto que aún hoy arroja muchos interrogantes, pero es, a la vez, un factor más, un elemento más que añadir a otros, a la hora de identificar (localizar, datar...) nuestras composiciones. Como tal, hay que valorar este método, y más importante aún, debemos propagarlo entre los profesionales, con vistas a que, en el plazo más breve posible, y merced al trabajo coordinado de historiadores y musicólogos, el método "crezca" ostensiblemente en el grado de fiabilidad que nos pueda aportar: acompañado siempre de otros factores (rasgos caligráficos de los copistas de música, estilo musical de la composición, etc.), y en la medida en que cada vez dispongamos de mayor número de filigranas recogidas en nuestro país, este método contribuirá, sin duda alguna, a datar, y situar con mayor detalle nuestra música.

66. De hecho, todavía contamos, por un lado, con una bibliografía al respecto bastante antigua en sus títulos fundamentales o de referencia (Briquet, Oriol Valls...), y por otro lado, con referencias muy dispersas (en artículos de diferente calado y disciplinas muy diversas), que en la mayor parte de los casos se refieren a documentación del período medieval, sobrepasando en casos contados la frontera del siglo XVI. 


\section{Bibliografía}

-E. Midoux; y A. Mathon: Études sur les filigranes des papiers employés aux XVè et XVè siècles. París, 1868. -Charles Moïse Briquet: Papiers et filigranes des archives de Gênes 1154 à 1700. Ginebra, H. Georg libraire-éditeur, 1888. -Id.: Les filigranes. Dictionnaire historique des marques du papier dès leur apparition vers 1282 jusqu'en 1600. 4 vols. Ginebra, 1907; 3 vols. París, Leipzig, 1923; reimp. 4 vols., Nueva York, 1966; Amsterdam, 1968 [edición facsímil con material suplementario]; Nueva York, 1977. [La obra fundamental en la materia, a pesar de que se realizara hace ya muchos años; recoge más de 16.000 filigranas europeas -con una pequeña representación española-, y aporta una de las primeras normativas al respecto]. -Lucien Wiener: Étude sur les Filigranes des Papiers Lorrains. Nancy, 1893. [Ejemplar consultado, procedente de la Biblioteca Universitaria de la Facultad de Filosofía y Letras de Zaragoza, signatura: 2-272]. -F. del Marmol: Dictionnaire des filigranes classés en groupe alphabétique et chronologique. Namur, 1900. -Francisco de A. de Bofarull y Sans: "La Heráldica en las filigranas del papel”, en Memorias de la Real Academia de Buenas Letras, VII, Barcelona, 1901, pp. 485-556. [Entre otras muchas, recoge la filigrana más antigua -de 1296del Archivo de la Corona de Aragón de Barcelona, sobre papel procedente de Roma]. (Traduc. al inglés por A. J. Henschel y B. A. Oxon, como Heraldic Watermarks. The Paper Publication Society, Hilversum -Holanda-, 1956). -Id.: Los animales en las marcas del papel. Villanueva y la Geltrú, Oliva impresor, 1910. -P. Heitz: Les filigranes avec la crosse de Bâle. Estrasburgo, 1904. -Dard Hunter: Hand made paper and its water marks. Nueva York, Burt Franklin ed., 1916 [Reprint, 1967]. [Ejemplar consultado, procedente de la Biblioteca Universitaria de la Facultad de Filosofía y Letras de Zaragoza, signatura: Despacho 136]. -Ramón Mena: Filigranas o marcas transparentes en papeles de Nueva España del siglo XVI. México, Secretaría de Relaciones Exteriores, 1926. -W. A. Churchill: Watermarks in paper in Holland, England, France, etc. in the XVII and XVIII Centuries and their interconnection. Amsterdam, Minno Hertzberger, 1935. -Edward Heawood: Watermarks. Hilversum, 1950. -Id.: "Watermarks mainly of the 17th and 18th Centuries (Monumenta charta papyracea historiam illustrantia, I). Hilversum: The Paper Publications Society. 1960. -A. Stevenson: "Watermarks are twins", en Studies in Bibliography, IV, 1952, pp. 57-91. -Roberto Ridolfi: Le filigrane dei paleotipi. (Saggio
Metodologico). Florencia, Tipografía Giustina, 1957; 45 pp. y 18 láminas. [Criterios aplicados en los estudios de los incunables]. -V. Mosin; y S. M. Traljic: Filigranes des XIIIè et XIVè siècles. 2 vols. Zagreb, 1957. -A. H. Shorter: "Paper mills and paper makers in England 1495-1800", en Monumenta charta papyracea historiam illustrantia. Hilversum. The Paper publications Society. 1957. -Jean Irigoin: "Les fligranes de Fabriano (noms de papetiers) dans les manuscrits grecs du debut du XIVè siècle", en Scriptorium, XII, 1958, pp. 44-50 y 281-282. -Id.: "La introduction du papier italien en Espagne", en Papiergeschichte, X, 1960, pp. 29-32. -Id.: "La datation par les filigranes du papier", en Codicologica. Les materiaux du livre manuscrit, V, 1980, pp. 9-36. -Id.: "La datation des papiers italiens des XIIlè et XIVè siècles", en Papiergeschichte, XVIII, 1968, pp. 49-52 y 76. -José Sánchez Real: "Las filigranas de animales en los Archivos de Tarragona", en Boletín Arqueológico, 61-64. Instituto de Estudios Tarraconenses «Ramón Berenguer IV», Sección de Arqueología e Historia. Tarragona, Diputación de Tarragona, Sugrañes Hnos. editores, 1959. -Id.: "Las filigranas del papel", en Ligarzas, IV. Valencia, Departamento de Historia Medieval, Facultad de Filosofía y Letras, Universidad de Valencia, 1972, pp. 259-266. -Id.: "Criterios a seguir en la recogida de filigranas”, íbid., VI, Valencia, 1974, pp. 361-371. -Id.: El papel y sus filigranas en los incunables tarraconenses. Tarragona, 1980. -C. Sarthou Carreres: Játiva, cuna del papel en Europa. Játiva, 1962. -G. Eineder: The Ancient Paper Mills of the former Austro-Hungarian Empire and their Watermarks. 1962. -J. Lindt: The Paper Mills of Berne and their Watermarks (14651859). Hilversum, 1964. -Oriol Valls i Subirà: Paper and Watermarks in Catalonia. Monumenta Charta Papyracea Historiam Illustrantia. (El Papel y sus filigranas en Cataluña). 2 vols. (XI-XII). Amsterdam, The Paper Publications Society (Labarre Foundation), 1970. -Id.: "La influencia de los estilos en las filigranas", en Pro-Arte, III, Barcelona, 1975, pp. 30-44. -Id.: La Historia del Papel en España. 3 volúmenes. I: Siglos X-XIV [cfr. pp. 226-260; II: Siglos XV-XVI [cfr. pp. 109-242]; III: Siglos XVII-XIX [cfr. pp. 11271; específicamente sobre la historia del papel en Aragón, vid. pp. 130-143, y sobre filigranas en Aragón, pp. 139-143]. Madrid, Empresa Nacional de Celulosas, 1978, 1980 y 1982. -Josep Ma Madurell i Marimón: El paper a les terres catalanes. Contribució a la seva Història. 2 vols. Barcelona, Fundació Salvador Vives 
Casajuana, 1972. -J. López Plá; y M. J. Martín Crego: "Filigranas del Archivo Municipal de Castellón de la Plana (Manual de Consells)", en Ligarzas, V. Valencia, Departamento de Historia Medieval, Facultad de Filosofía y Letras, Universidad de Valencia, 1973, pp. 8-109. -V. Mosin: Anchor Watermarks, en (Monumenta charta papyracea historiam illustrantia). Hilversum. The Paper Publications Society, 1973. -G. Gayoso Carreira: "Antigua nomenclatura papelera española”, en Investigación y Técnica del Papel, X, 35, 1973. [Sobre la terminología papelera]. -J. $M^{a}$ Doñate Sebastiá: "Filigranas del Archivo Municipal de Villarreal", en Ligarzas, V. Valencia, Departamento de Historia Medieval, Facultad de Filosofía y Letras, Universidad de Valencia, 1973, pp. 111-244. -M. Th. Gerardy: "Les techniques d'examen des filigranes", en Les techniques de laboratoire dans l'etude des manuscrits, París, 1974, pp. 143-157. -M $\mathrm{M}^{\mathrm{a}}$ Luisa Cabanes Catalá; Milagros Cárcel Orti; y $\mathrm{M}^{\mathrm{a}}$ Carmen Yago Andrés: "El Archivo de la Colegiata de Játiva y sus filigranas". Ligarzas, VI. Valencia, Departamento de Historia Medieval, Facultad de Filosofía y Letras, Universidad de Valencia, 1974, pp. 5-120. [Sólo cubre los años 1357 a 1505]. - $\mathrm{M}^{\mathrm{a}}$ Desamparados Cabanes Pecourt; y M ${ }^{\mathrm{a}}$ Luisa Cabanes Catalá: "Las filigranas del Archivo Municipal de Estella", en Príncipe de Viana, 136 y 137. Institución Príncipe de Viana, Diputación Foral de Navarra. Pamplona, ed. Aranzadi, 1974, pp. 483-505. [Recoge 108 filigranas navarras y españolas de los siglos XVI y XVII —entre 1510 y 1699-, procedentes de una documentación muy variada, de índole no musical; sigue la normativa y nomenclatura del francés Briquet, analizando las concordancias existentes entre las marcas de agua recogidas en Estella y las que da Briquet]. -Luis Ariño Rico: "Filigranas de Mosqueruela", en Ligarzas, VI. Valencia, Departamento de Historia Medieval, Facultad de Filosofía y Letras, Universidad de Valencia, 1974, pp. 121-359. -H. M. Fiskaa; y O. K. Nordstrand: Paper and Watermarks in Norway and Denmark. 1978. -Juan y Juana $\mathrm{M}^{\mathrm{a}}$ Abellán Pérez: "Las filigranas medievales del Archivo Municipal de Murcia (13991455)", en Miscelánea Medieval Murciana, VI, Departamento de Historia Medieval, Universidad de Murcia. Murcia, Imprenta Nogués, 1980, pp. 133-146. -Germán Orduna: "Registro de filigranas de papel en códices españoles", en Incipit. Buenos Aires, Seminario de Edición y Crítica Textual. Consejo Nacional de Investigaciones Científicas y Técnicas de la Argentina. I, 1981, pp. 25-30; II, 1982, pp. 55-59; V, 1985, pp. 5-10; VII, 1987, pp. 1-6. -Josepa Cortès: "Filigranes medievals de l'Arxiu Municipal de Sueca (1399-1500)", en
Quaderns de Sueca, V. Departament de Paleografia i Diplomàtica, Universitat de València. Serie Inventaris, 6. Valencia, 1984, pp. 9-48. -Ricardo Córdoba de la Llave; y Manuel Cerezo Villegas: "Filigranas del Archivo Municipal de Córdoba (1450-1550)", en Anales de la Universidad de Alicante. Departamento de Historia Medieval, $\mathrm{n}^{\circ}$ 6, Alicante, Imprenta de la Universidad, 1987 (1988), pp. 407-434. -Monique Zerdoun Bat-Yehouda: Les papiers filigranés médievaux: essai de méthodologie descriptive. Turnhout, Brepols, 1989 (2 vols.). -Sonia Scott Fleming: The Analysis of Pen Flourishing in Thirteenth-Century Manuscripts. Leiden-Nueva York-Copenhague-Colonia, E. J. Brill, 1989. [No específicamente sobre filigranas, aunque trata acerca del trazo y modo de delinear iniciales en manuscritos y decoraciones semejantes al "estilo" de las filigranas]. -José Sánchez Real y Jesús E. Hernández Sanchis: "Las filigranas medievales del Archivo Municipal de Alzira", en Al-Gezira, VI, 1990, pp. 145202. -José Luis Basanta Campos: "Antonio Odriozola y las marcas de agua", en El museo de Pontevedra, XLIV, 1990, pp. 127-149. -Josepa Cortès Escrivà: "El paper i les filigranes", en La impremta valenciana, Valencia, Generalitat Valenciana, 1990, pp. 143-154. Gemma Avenoza y Germán Orduna: "Registro de filigranas de papel en códices españoles", en Incipit, X, pp. 1-15 se recogen 40 marcas procedentes de bibliotecas de Barcelona y aledaños]. -Id.: "Id. (cont.)", en Ibid., XI, 1991, pp. 1-9. -Gemma Avenoza: "Id.", en Ibid., XIII, 1993, pp. 1-13. -Maxim P. A. M. Kerkhof: "Las filigranas del manuscrito $\mathrm{S}$ del Libro de Buen Amor", en Incipit, XIII, 1993, pp. 15-20. -Gonzalo Gayoso Carreira: Historia del papel en España. 3 vols. Lugo, 1995. -Carmen Hernández García: "Orientaciones para la formación de un corpus de filigranas", en Normas internacionales para la catalogación de fuentes musicales históricas. RISM Serie A/II, Manuscritos musicales 1600-1850, edn. a cargo de José V. González Valle, Antonio Ezquerro, Nieves Iglesias, C. José Gosálvez, y Joana Crespí. Madrid, Anabad-Arco Libros, 1996, pp. 162-168. -José Luis Basanta Campos, coord.: Marcas de agua en documentos de los archivos de Galicia. Pontevedra, Fundación Pedro Barrié de la Maza, 1996. -María Rosario Valenzuela Marco: "Filigranas en el Archivo Histórico Provincial de Teruel", en Teruel, LXXXV/2, 1997, pp. 59-98. [Recoge 159 filigranas]. -Harald Kümmerling: Katalog der Sammlung Bokemeyer. Kassel, Bärenreiter, s.f. [Ejemplar consultado, procedente de la Biblioteca Universitaria de la Facultad de Filosofía y Letras de Zaragoza, signatura: $32-5 / 79]$. 


\section{CÍRCULO}

[1]

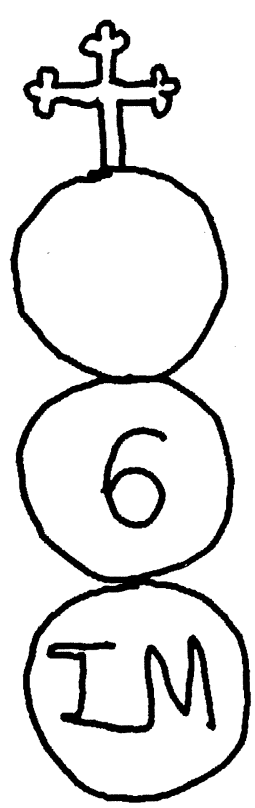

[2]

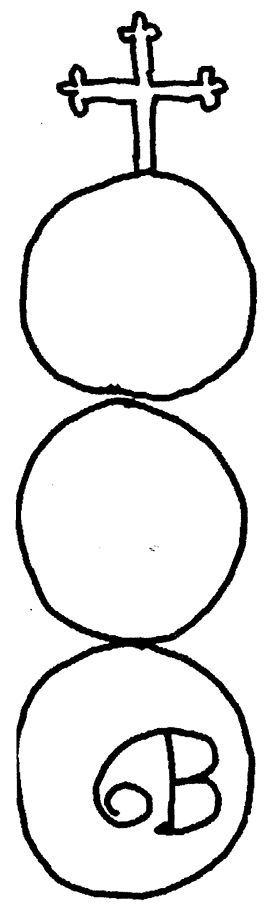

[5]

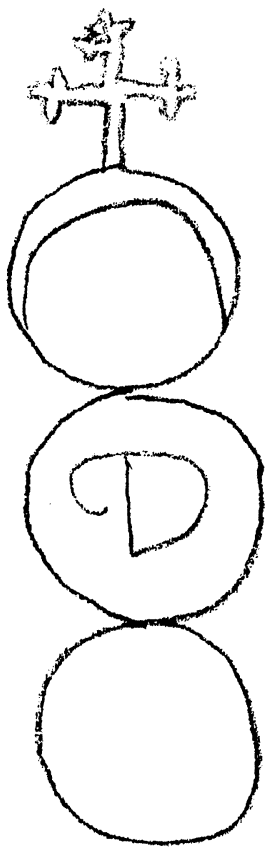

[3]

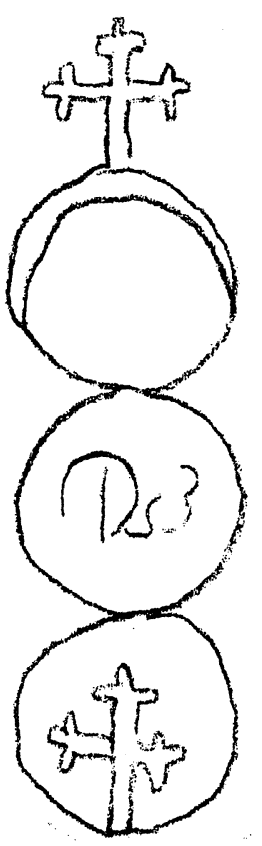

[4]

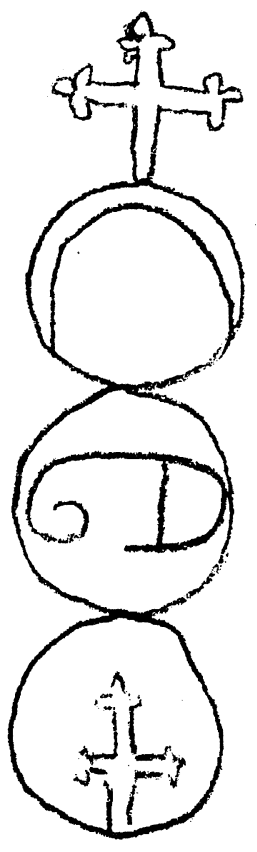

[6]

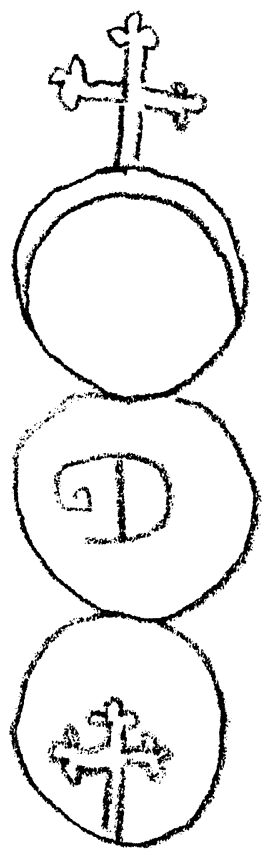


[7]

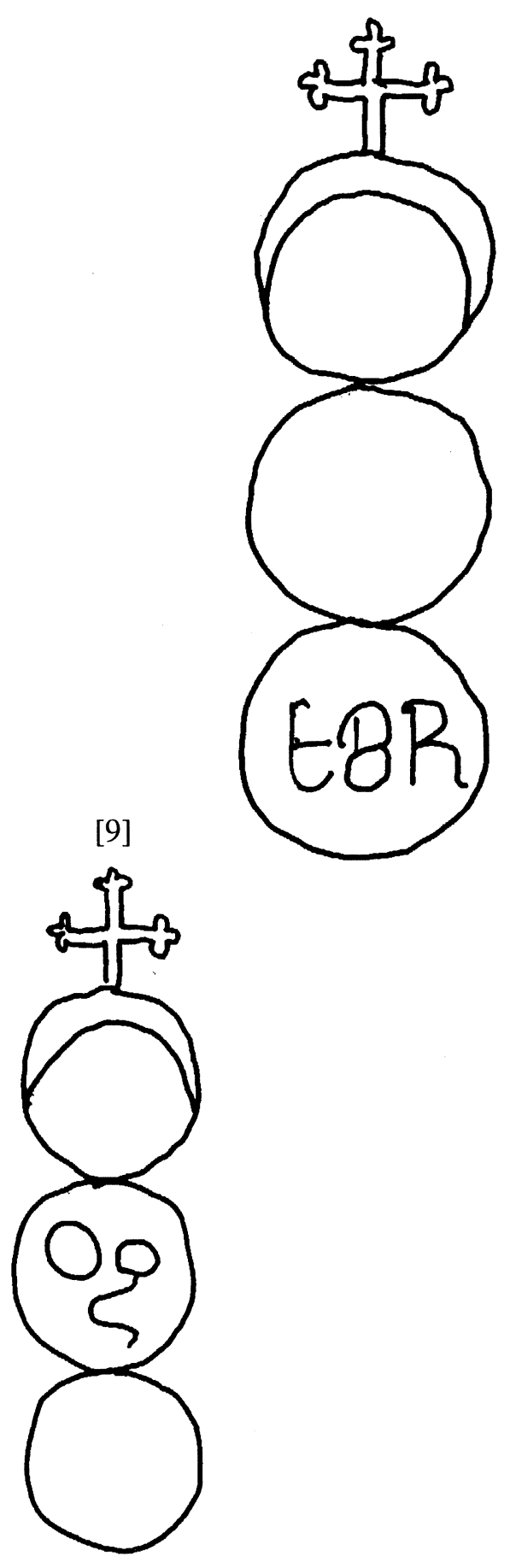

[8]

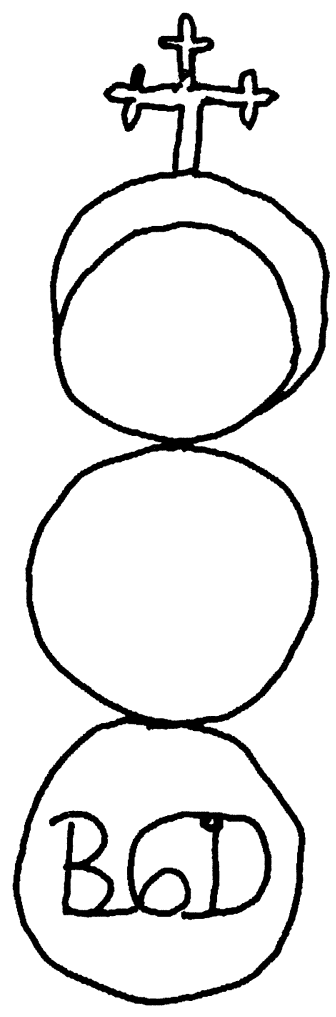

[11]

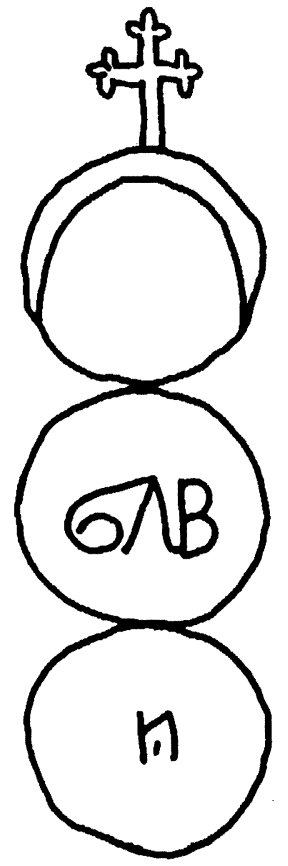

Anuario Musical, 55 (2000)

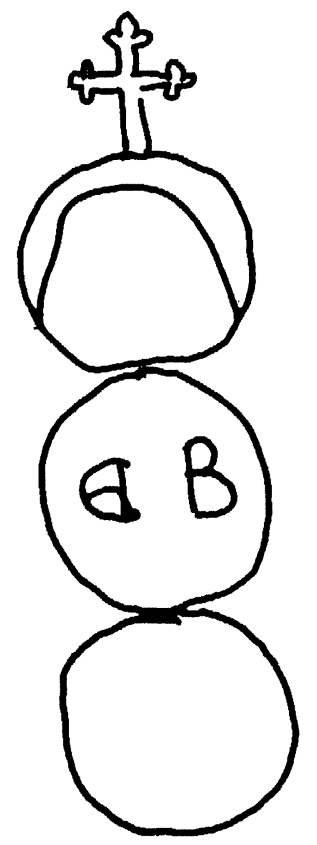


[12]

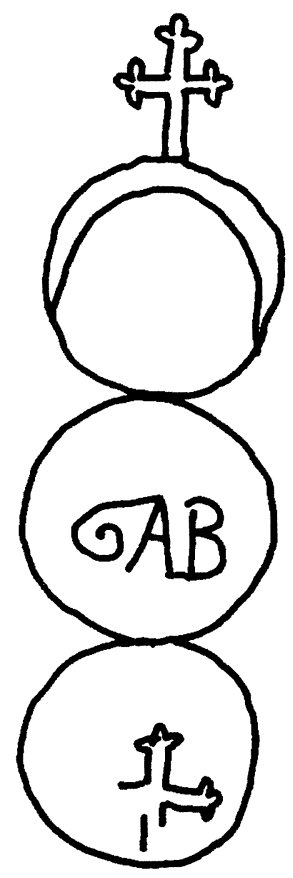

[16]
[13]

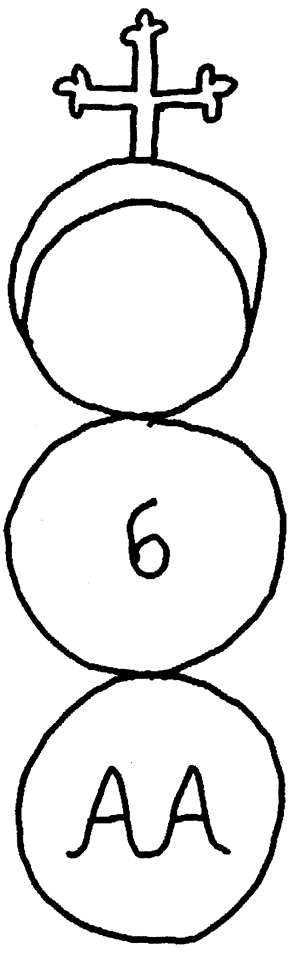

[14]

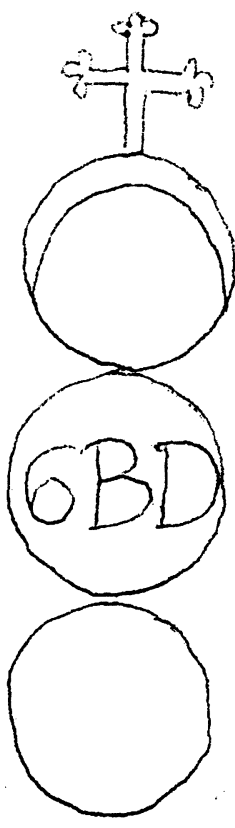

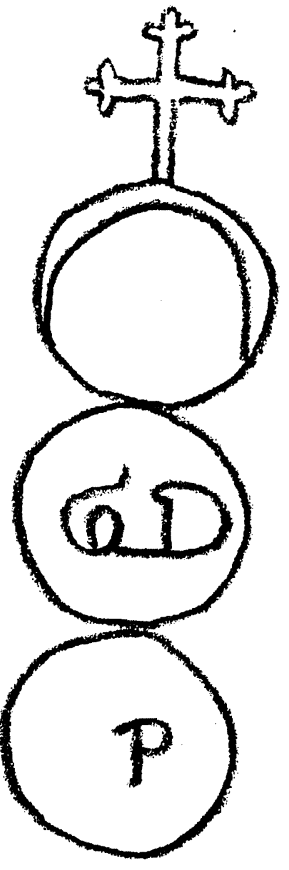

[17]
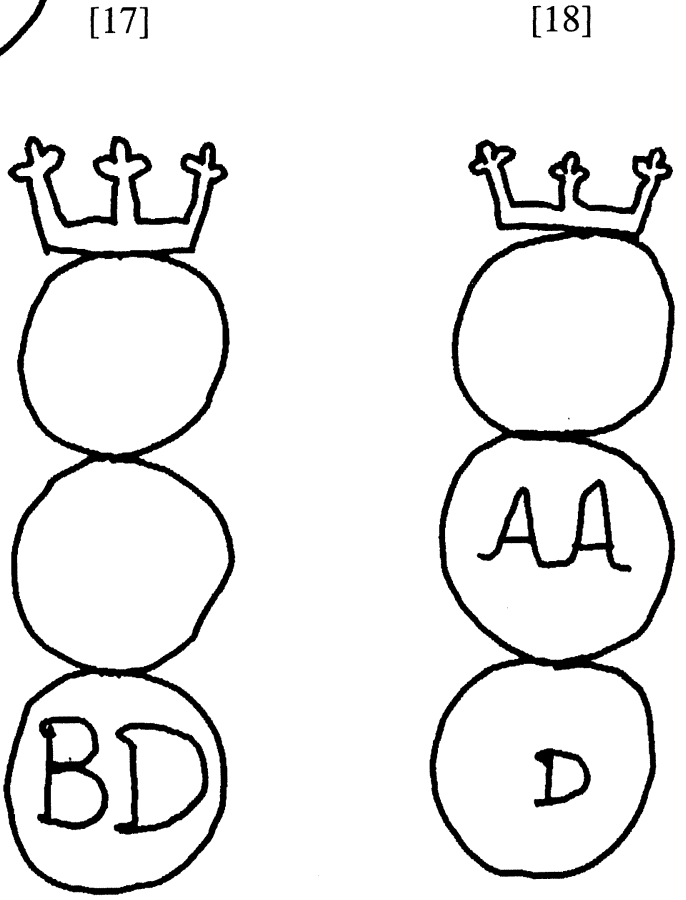

Anuario Musical, 55 (2000)

http://anuariomusical.revistas.csic.es

(c) Consejo Superior de Investigaciones Científicas Licencia Creative Commons 


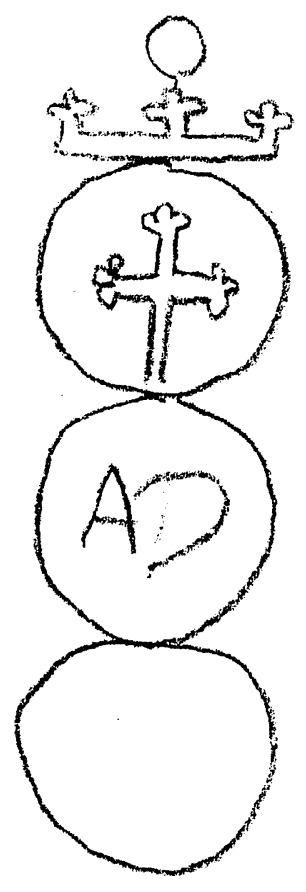

[23]

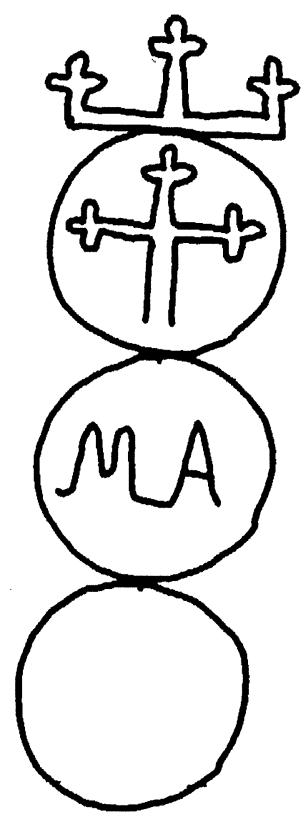

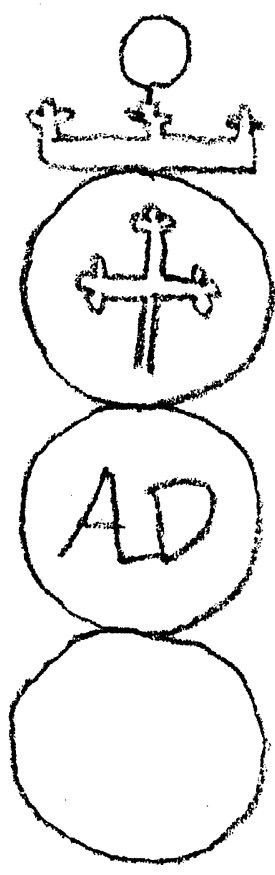

[24]

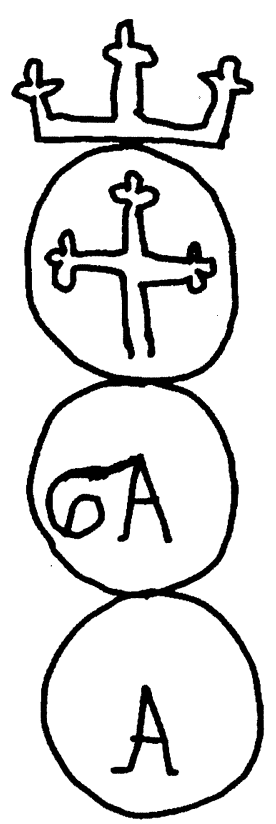

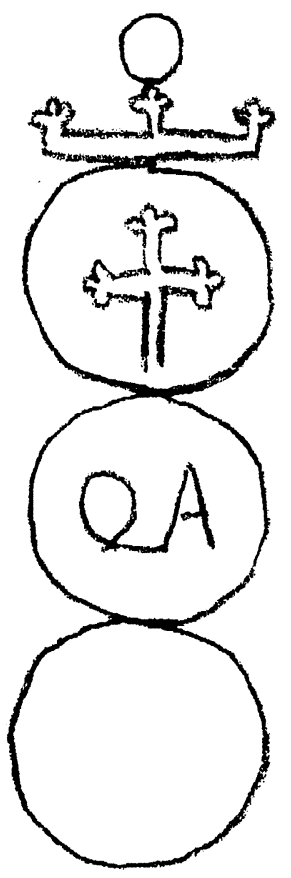

[25]

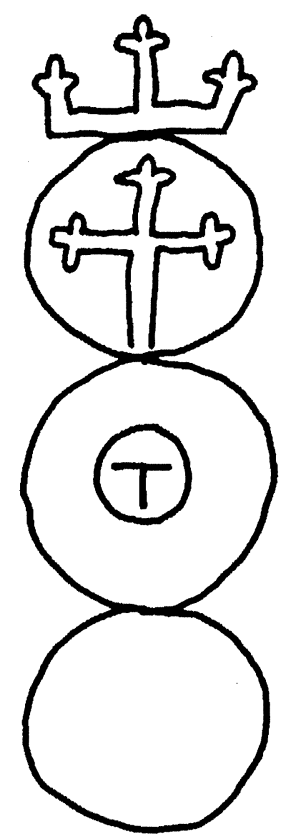

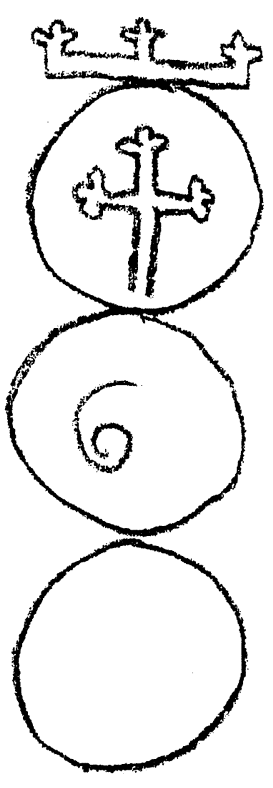

[26]

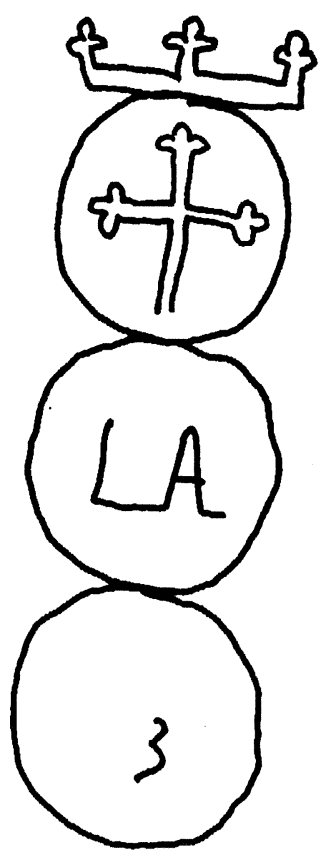

47 

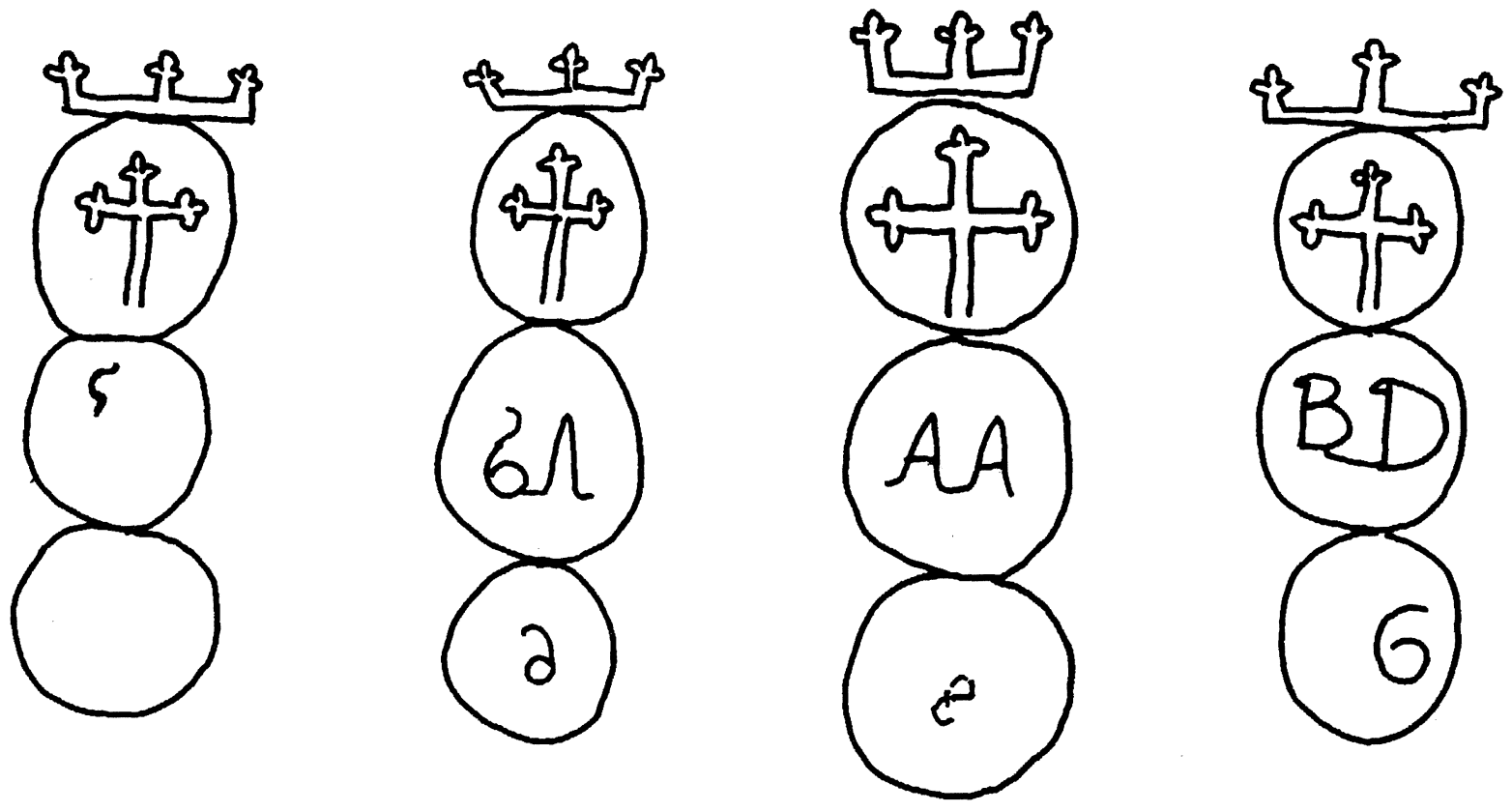

[31]

[32]

[33]

[34]
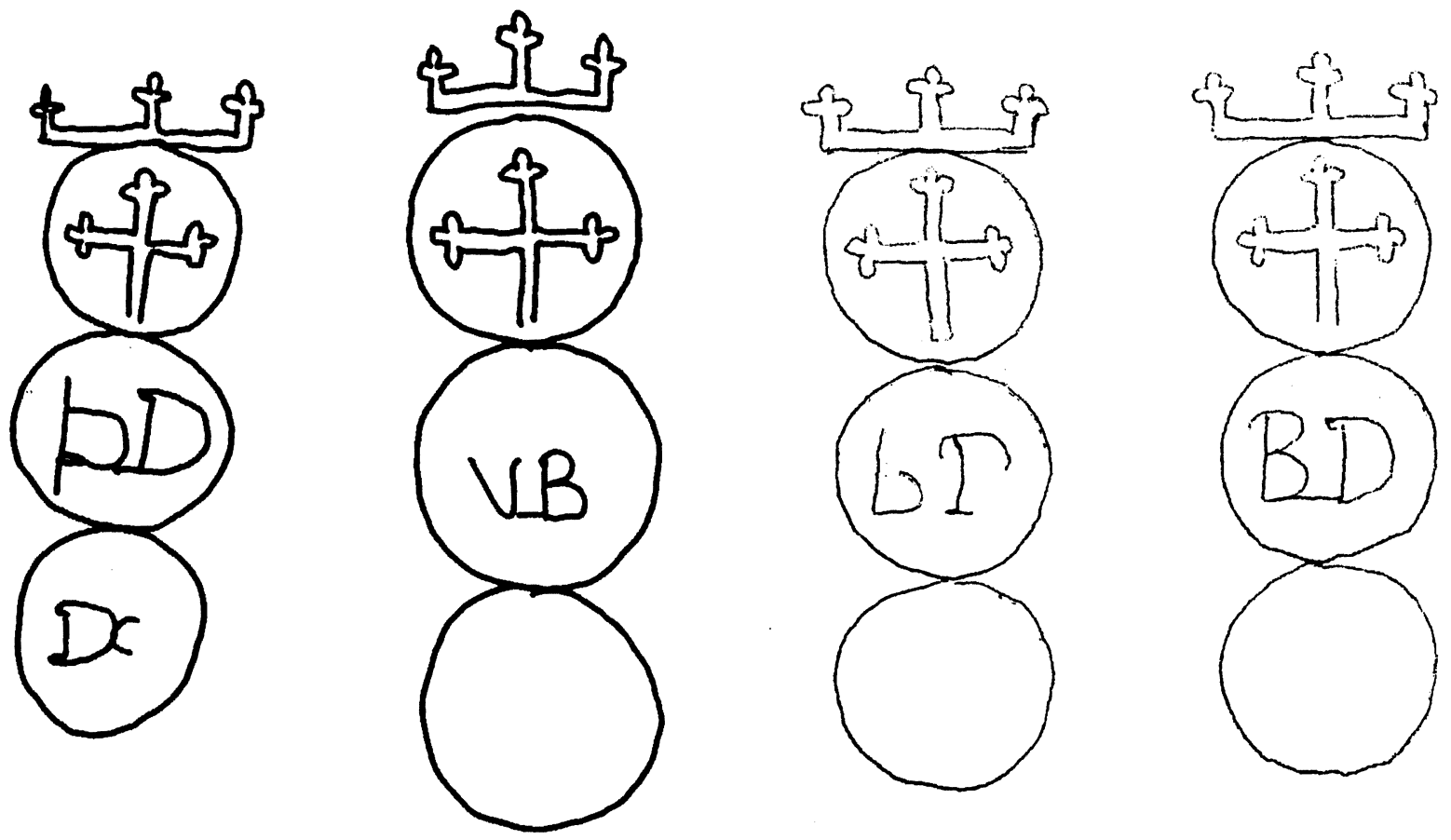

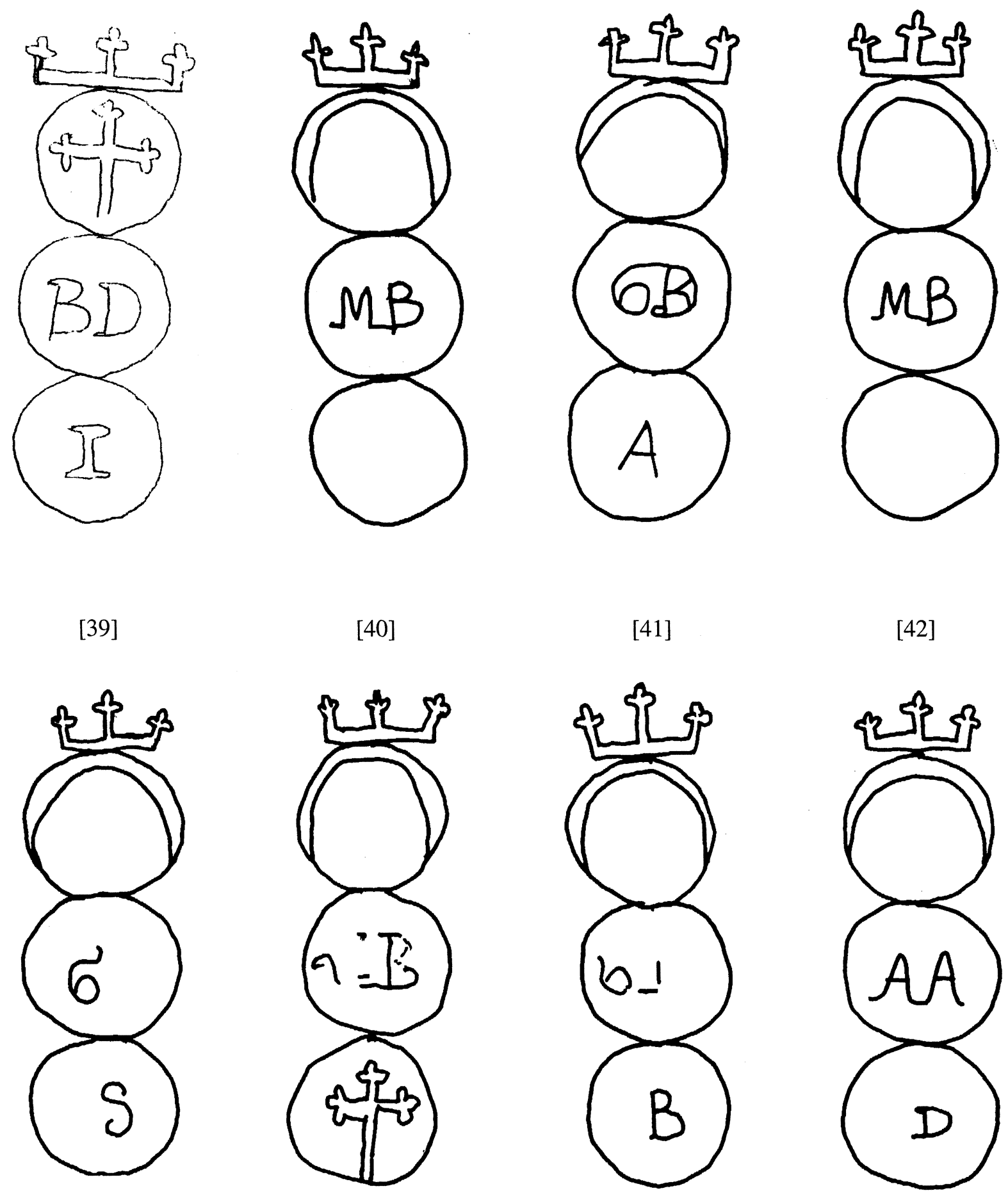


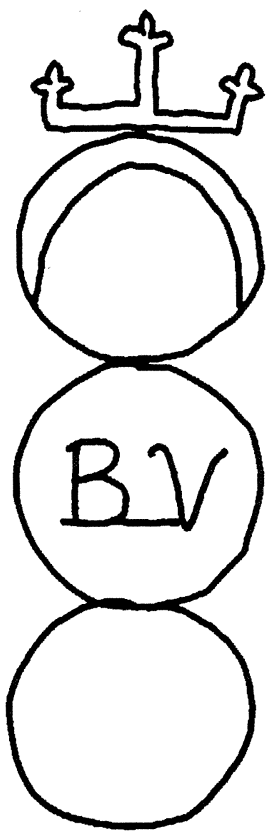

[47]

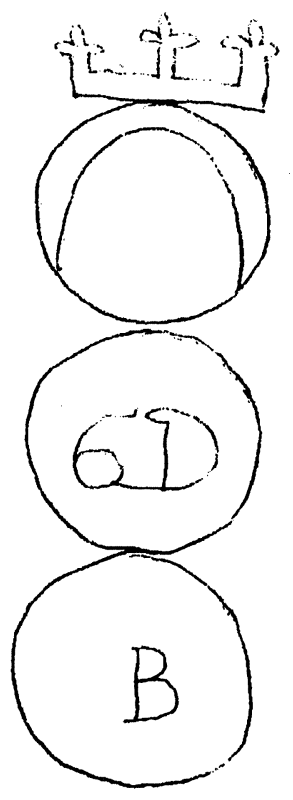

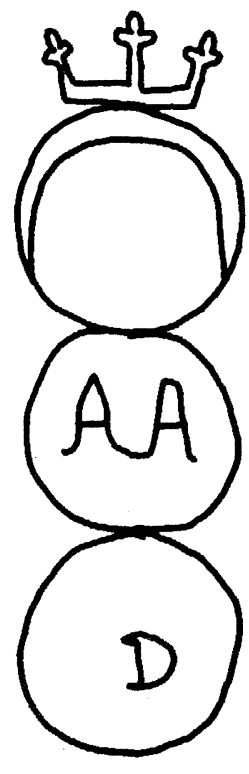

[48]

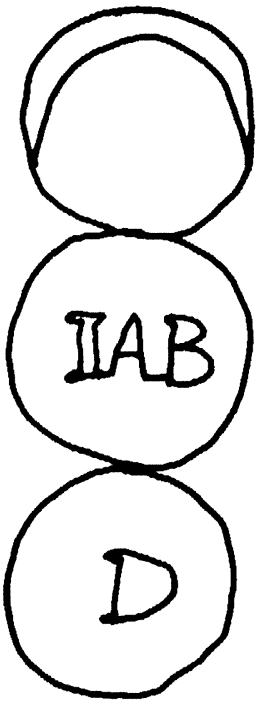

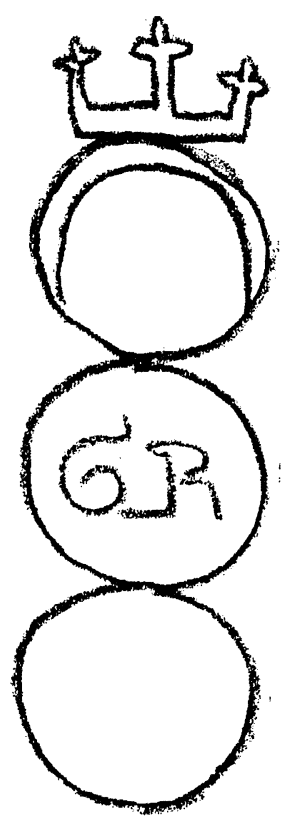

[49]

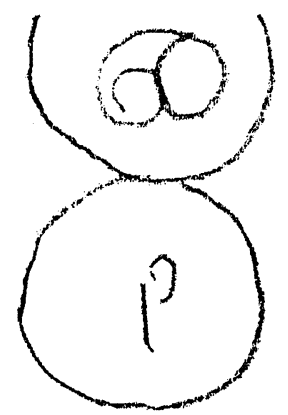

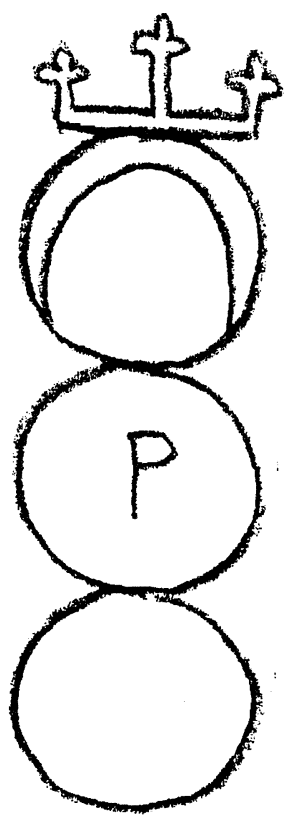

[50]

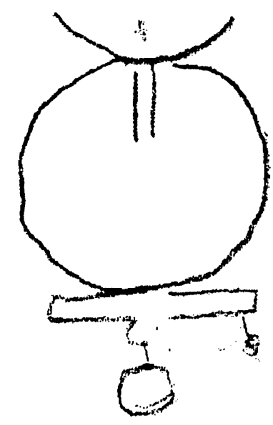




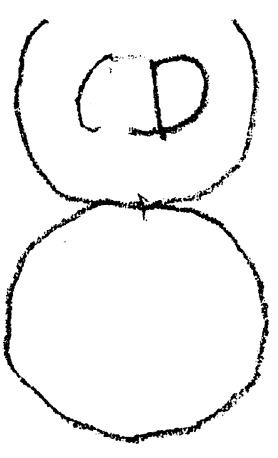

[55]

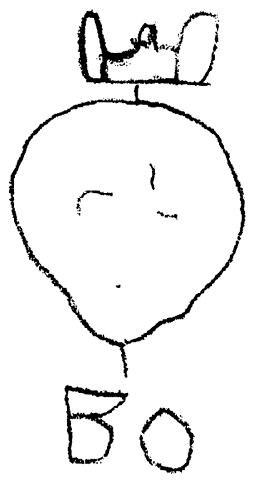

[59]

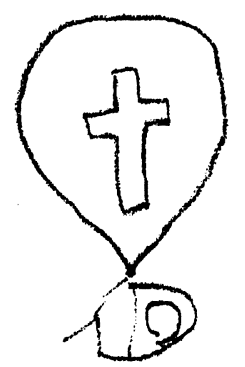

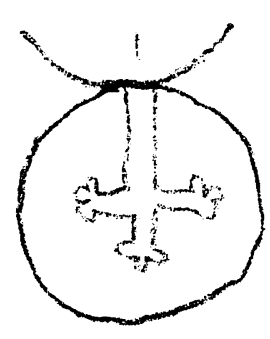
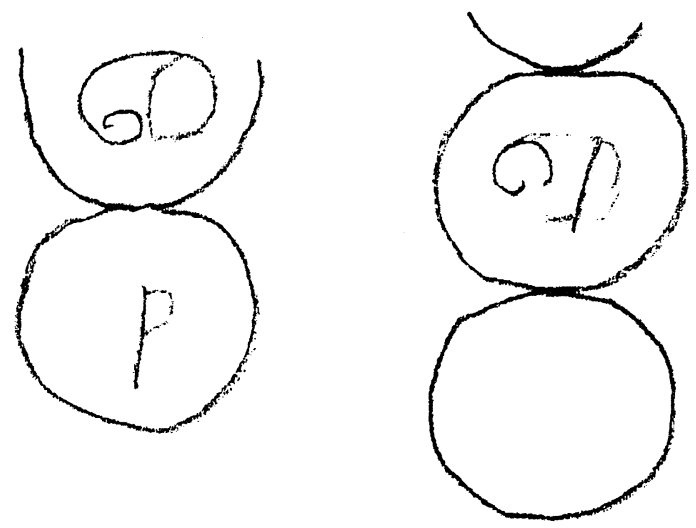

CRUZ
[57]

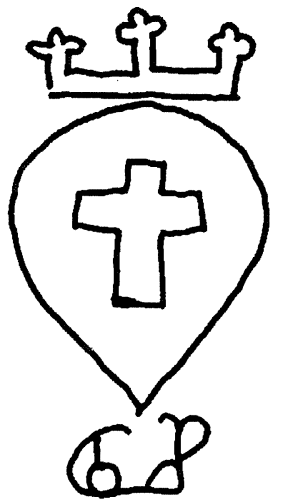

[61]

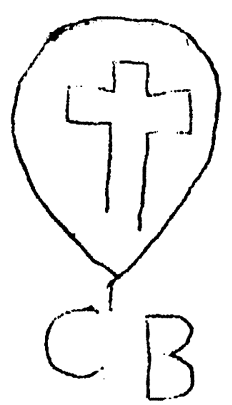

[58]

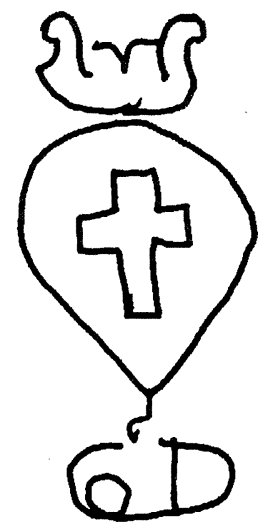

[60]

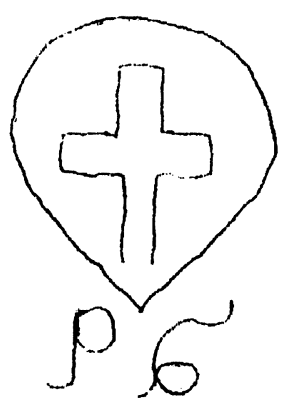

[62]

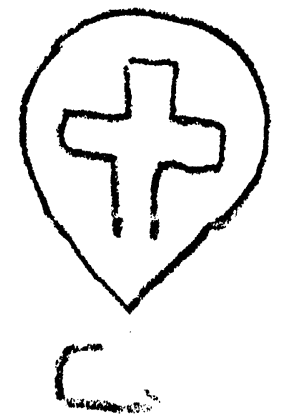

Anuario Musical, 55 (2000) 
[63]

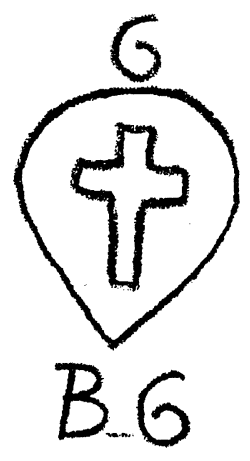

[67]

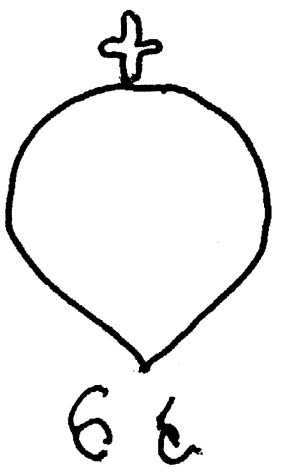

[71]
[64]

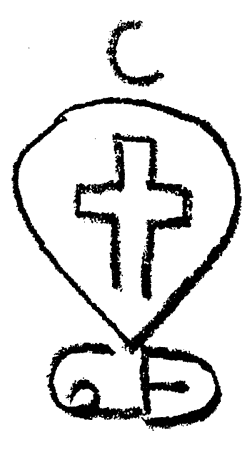

[68]

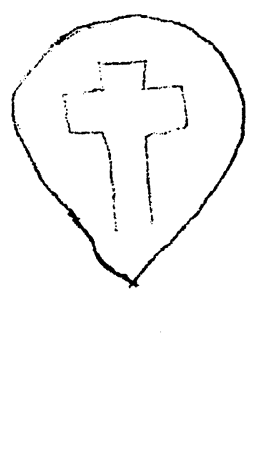

[65]

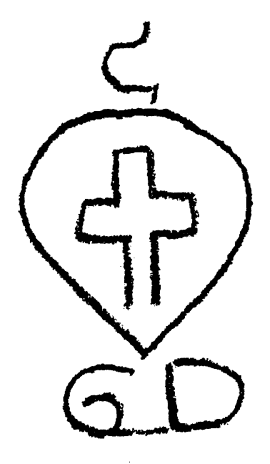

[69]

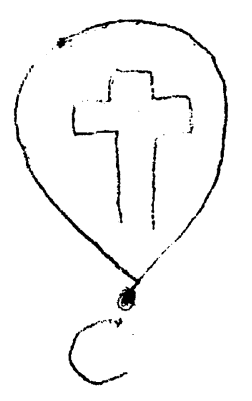

[66]

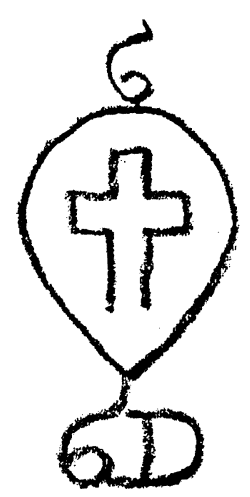

[70]

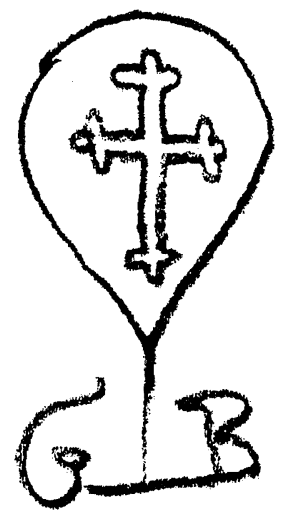

\section{ESCUDO}

[72]

[73]

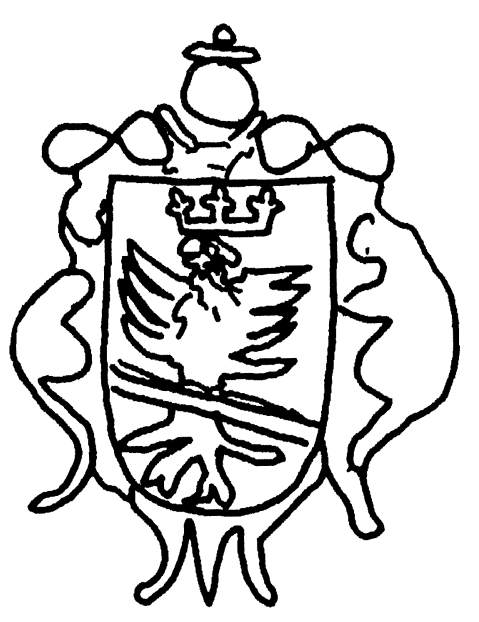

52

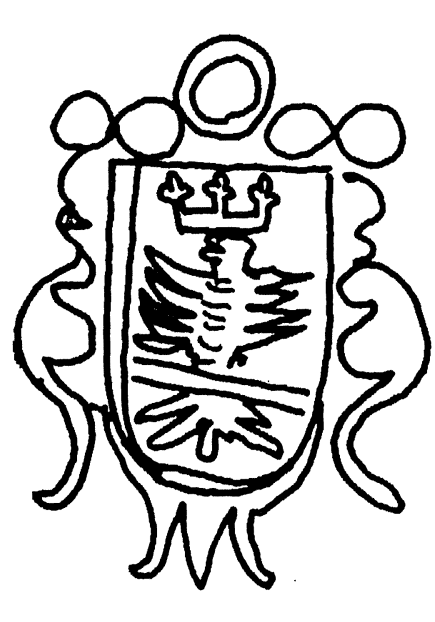

Anuario Musical, 55 (2000)

http://anuariomusical.revistas.csic.es

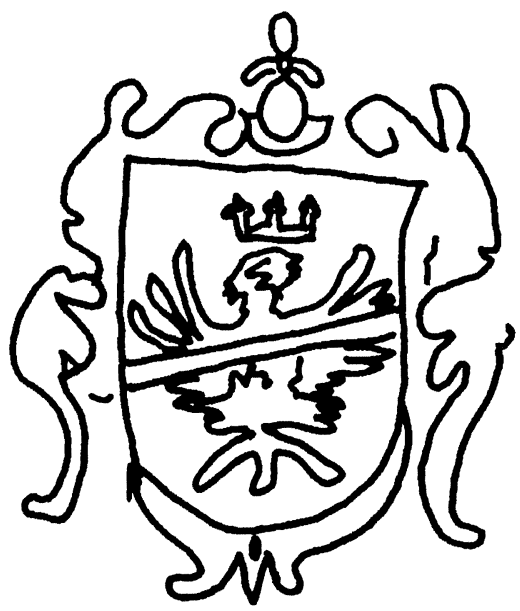


[74]

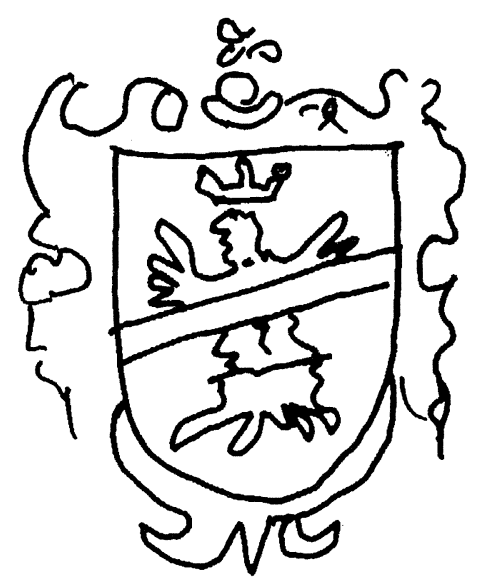

[75]

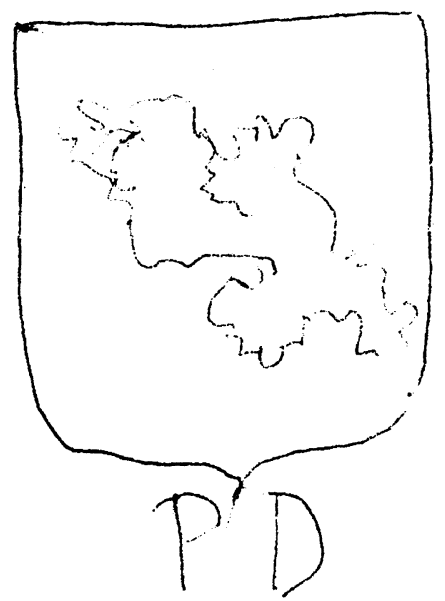

\section{ESFERA}

[76]

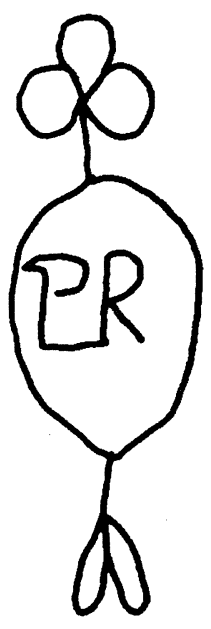

\section{LETRA}

[77]

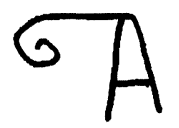




\section{LETRAS ENTRELAZADAS}
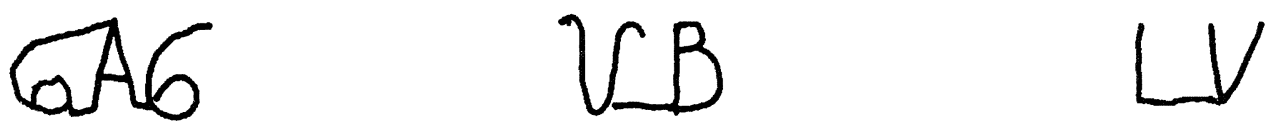

[81]

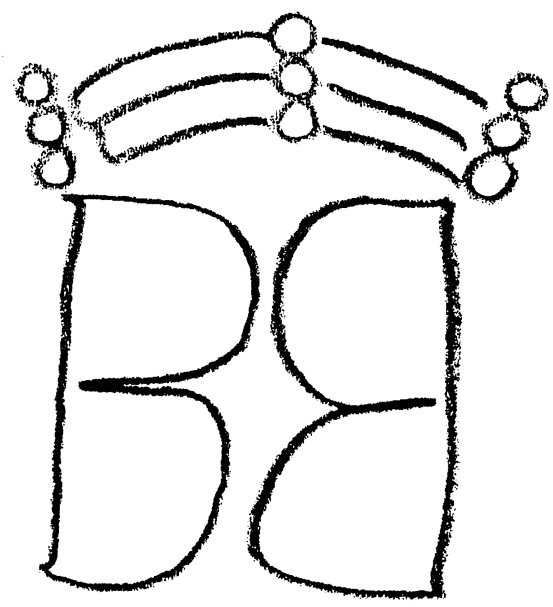

MANO

[82]
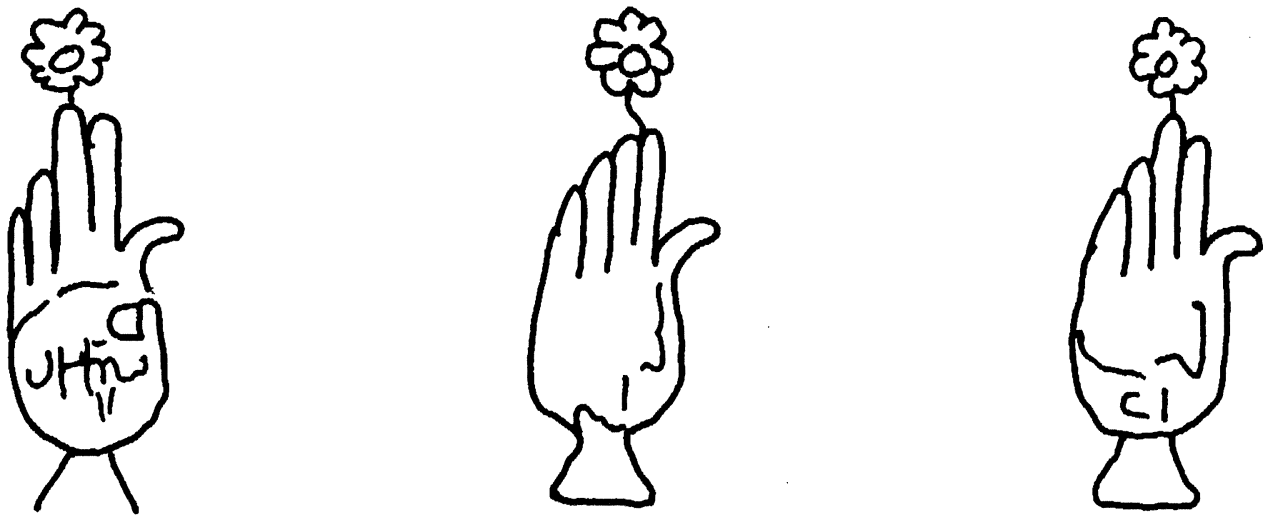


\section{INDETERMINADO}

\section{[83]}

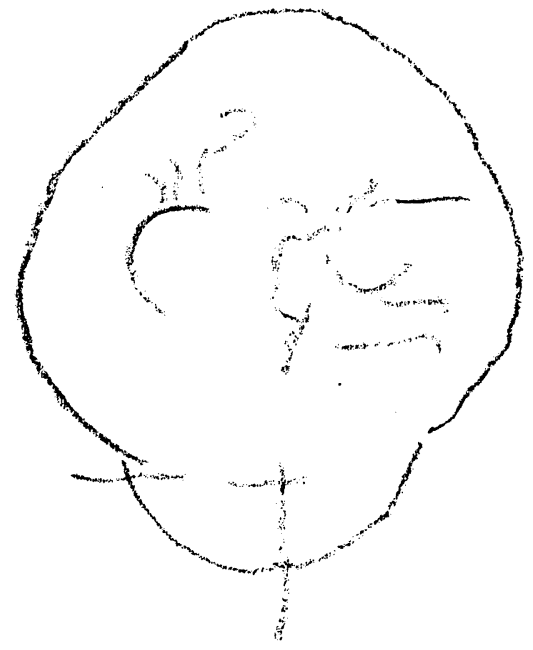

[84]

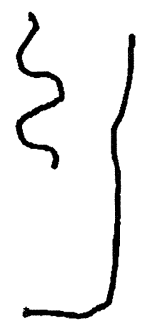




\section{ANEXO}

[Bayerische Staatsbibliothek, Munich]

[85]

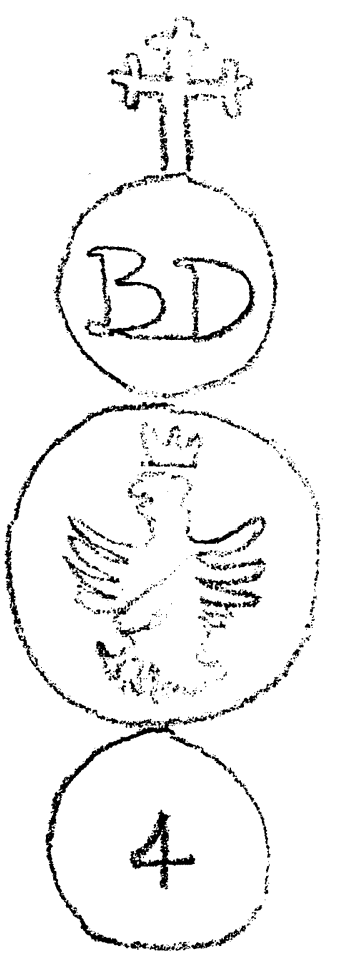

[86]

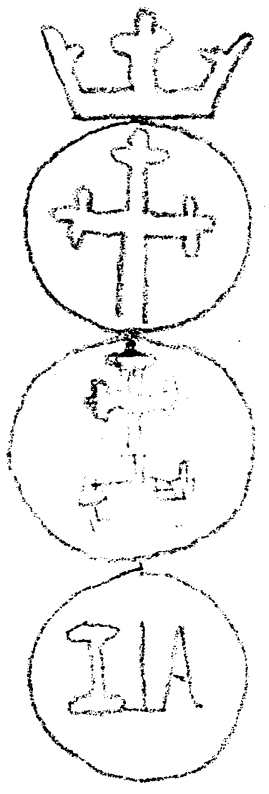

[89]

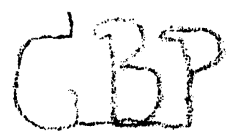

[87]

[88]
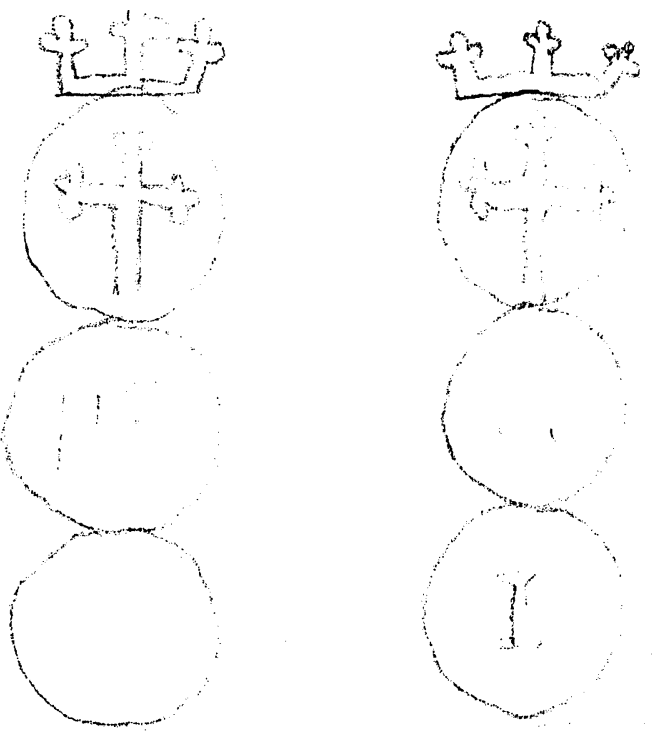

[90]<smiles>CCC[Te]C</smiles> 

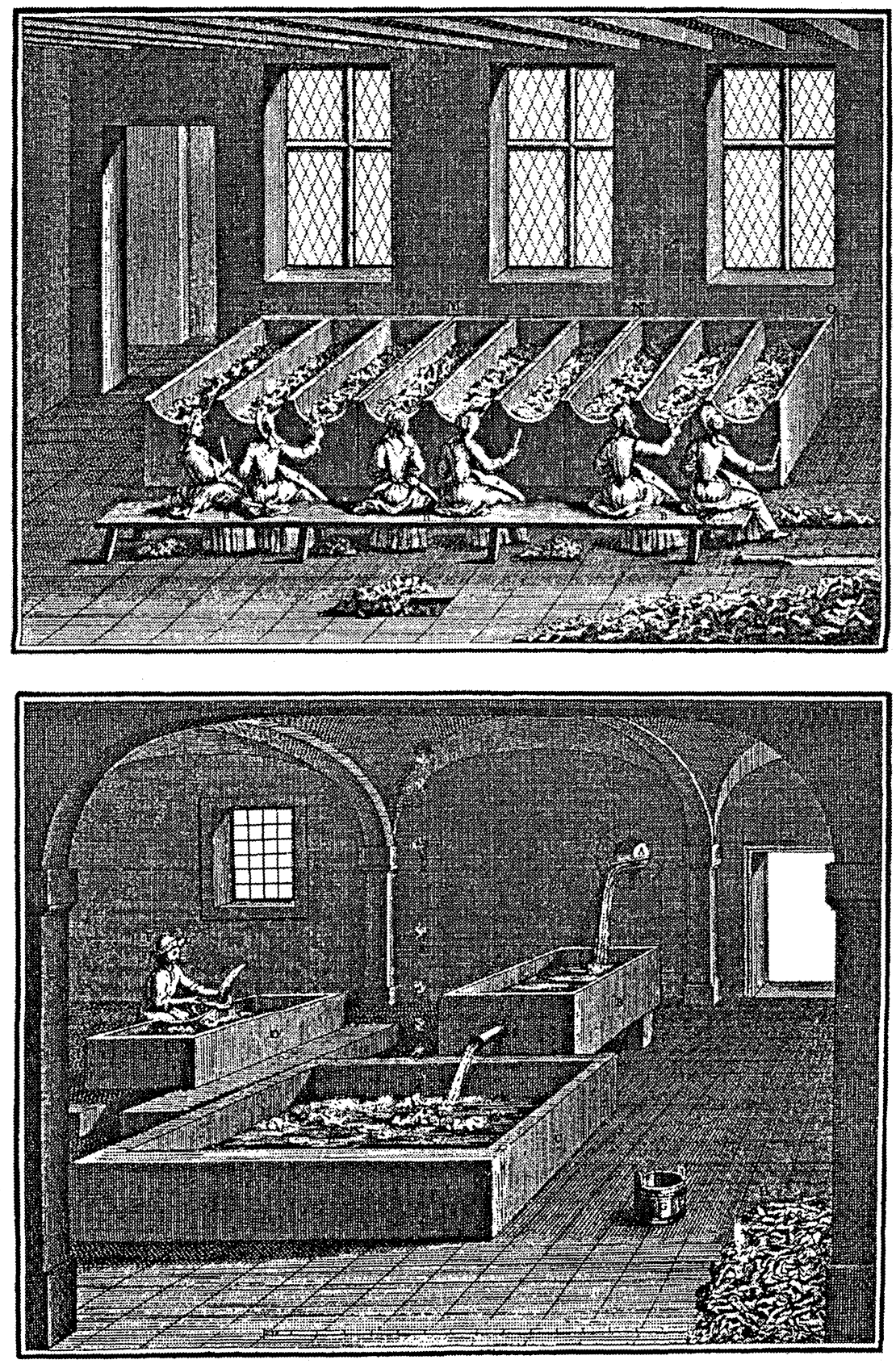

J. J. Lalande: Art de faire le papier (1761). Grabados de la edición italiana (1762). (Su traducción castellana data de 1778).

1. Selección de trapos en el molino, según su calidad.

2. Bolsas de fermentación. 

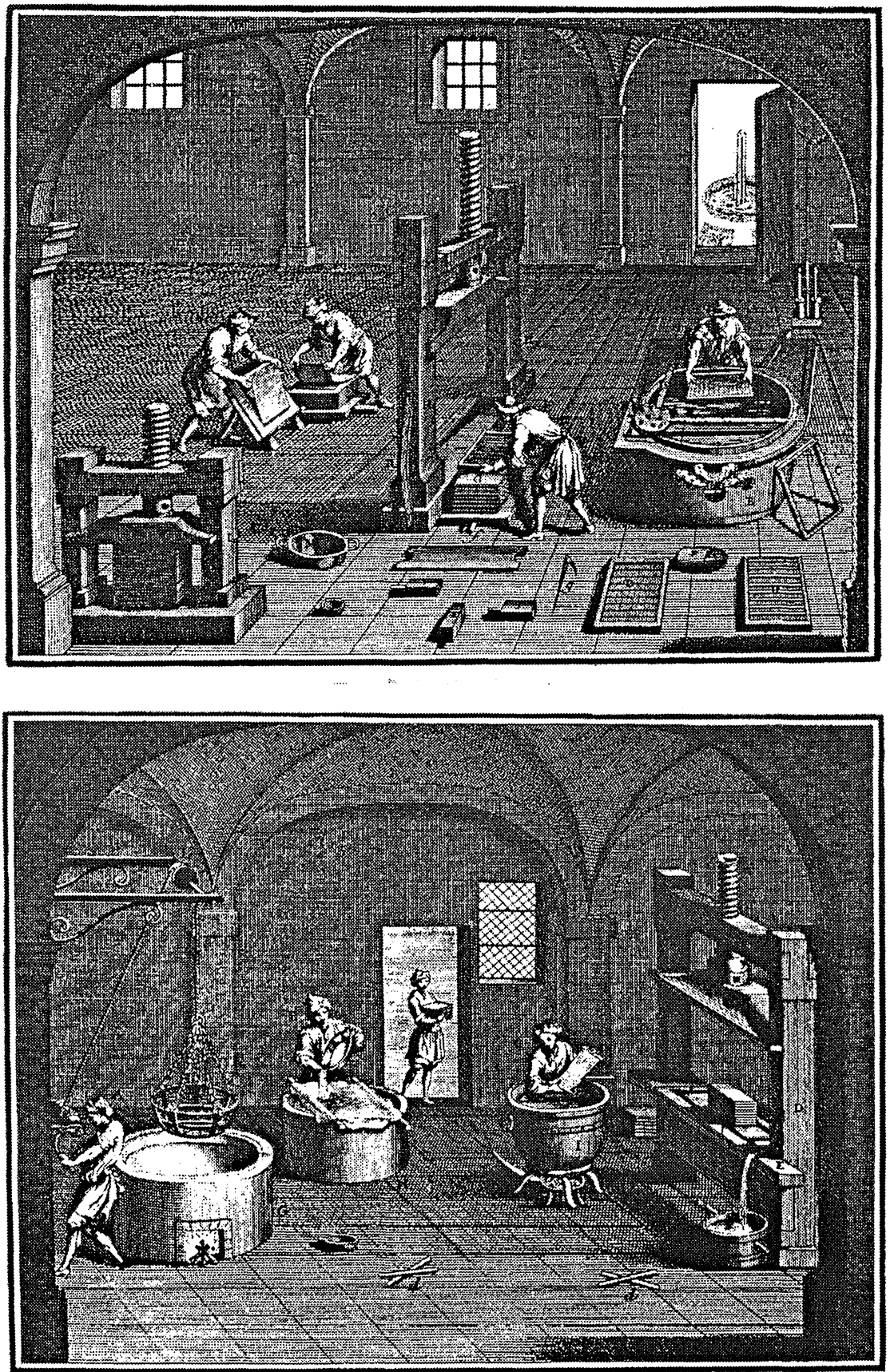

J. J. Lalande: Art de faire le papier (1761).

3. Tina, formas y prensas.

4. Encolado. 


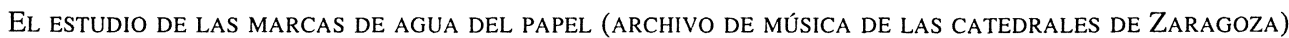
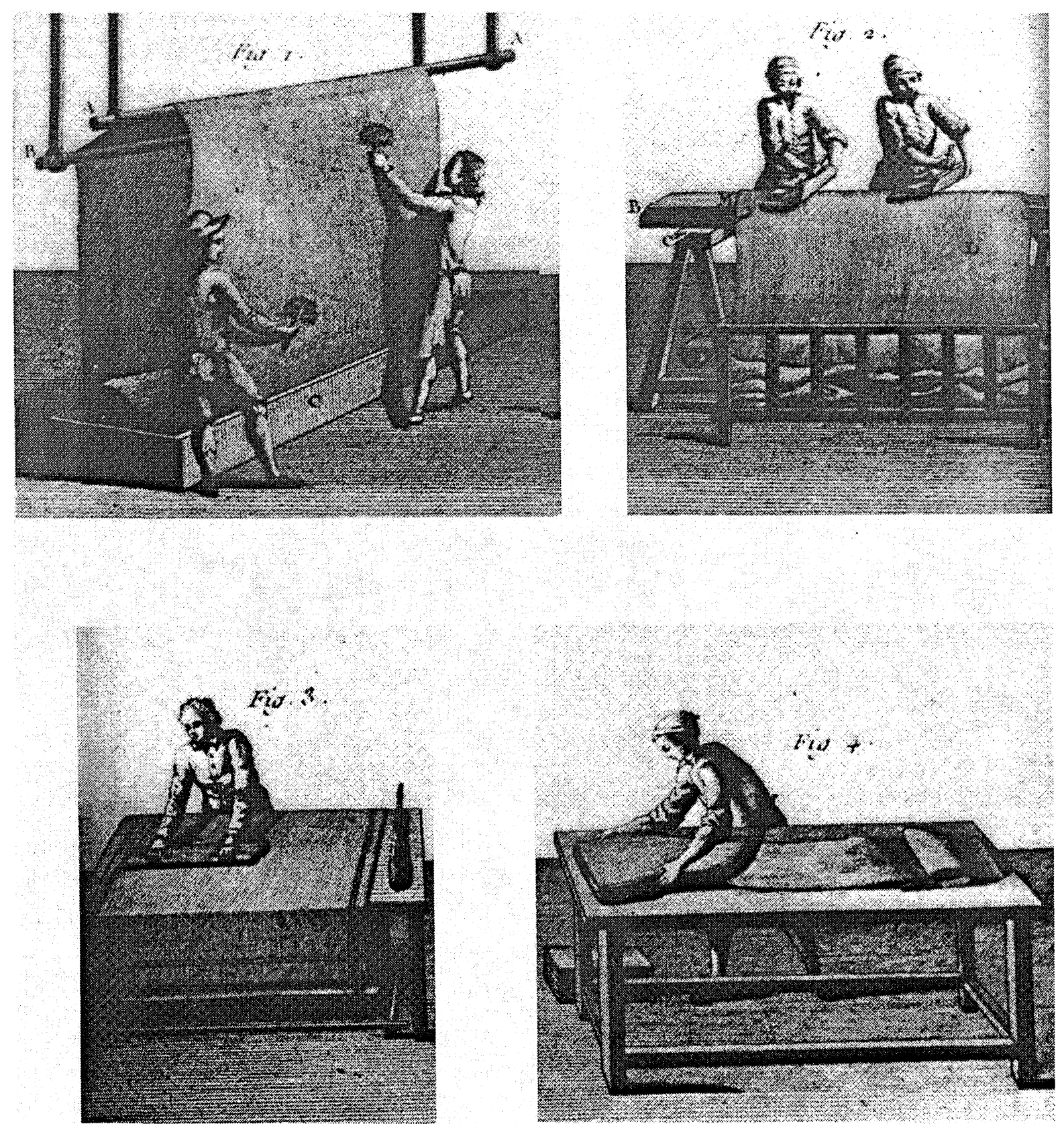

Fases del trabajo en el papel con un molino trapero, según una plancha de L'Encyclopédie (1786) 


\section{Der Bucḩoricter.}

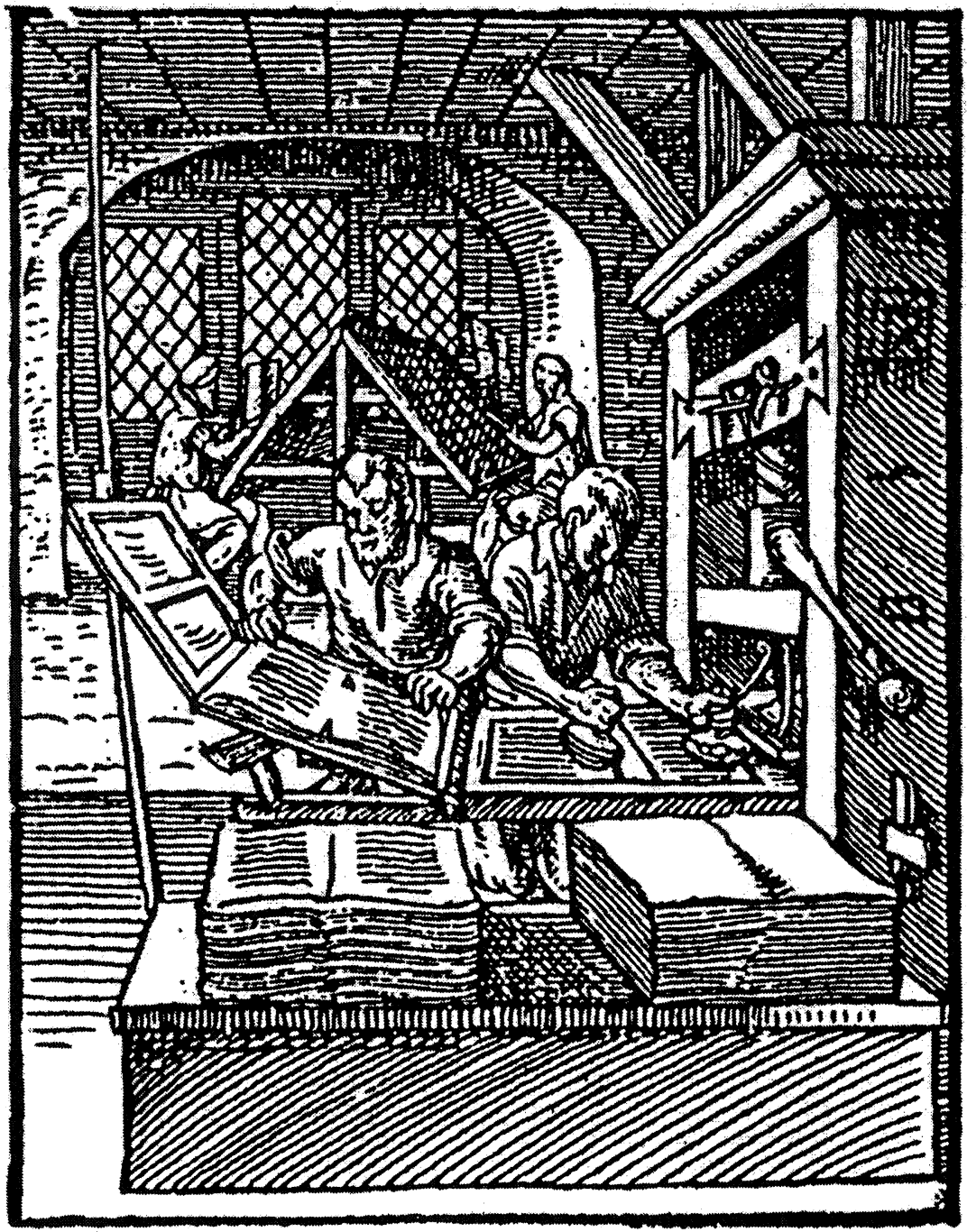

Antigua imprenta, similar a la empleada por Gutemberg

(en primer término, impresor y batidor a su derecha, entintanto un molde; al fondo, dos cajistas colocando los tipos en el galerín para componer un molde). 


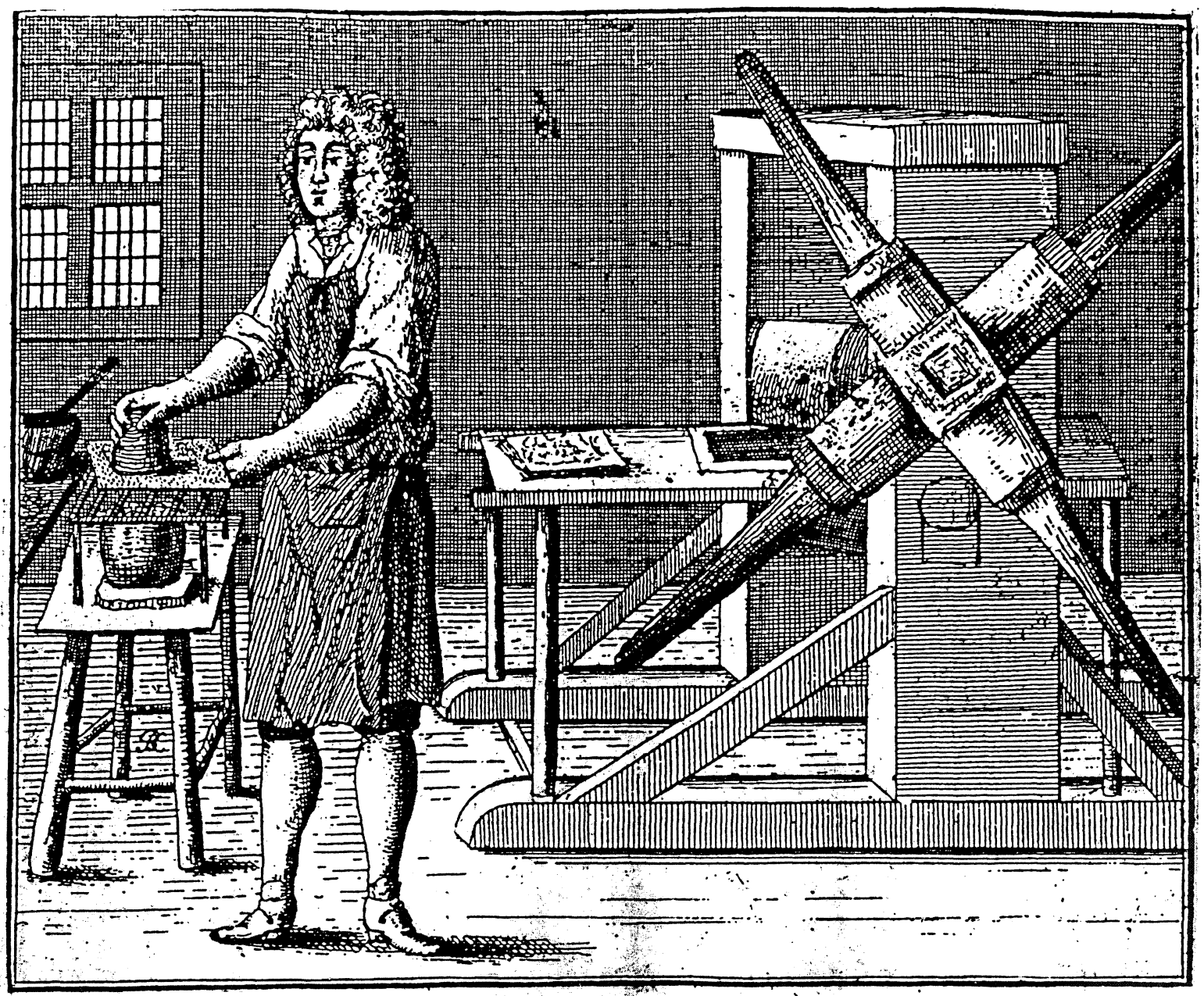

Taller de un grabador inglés (fines del siglo XVII). 


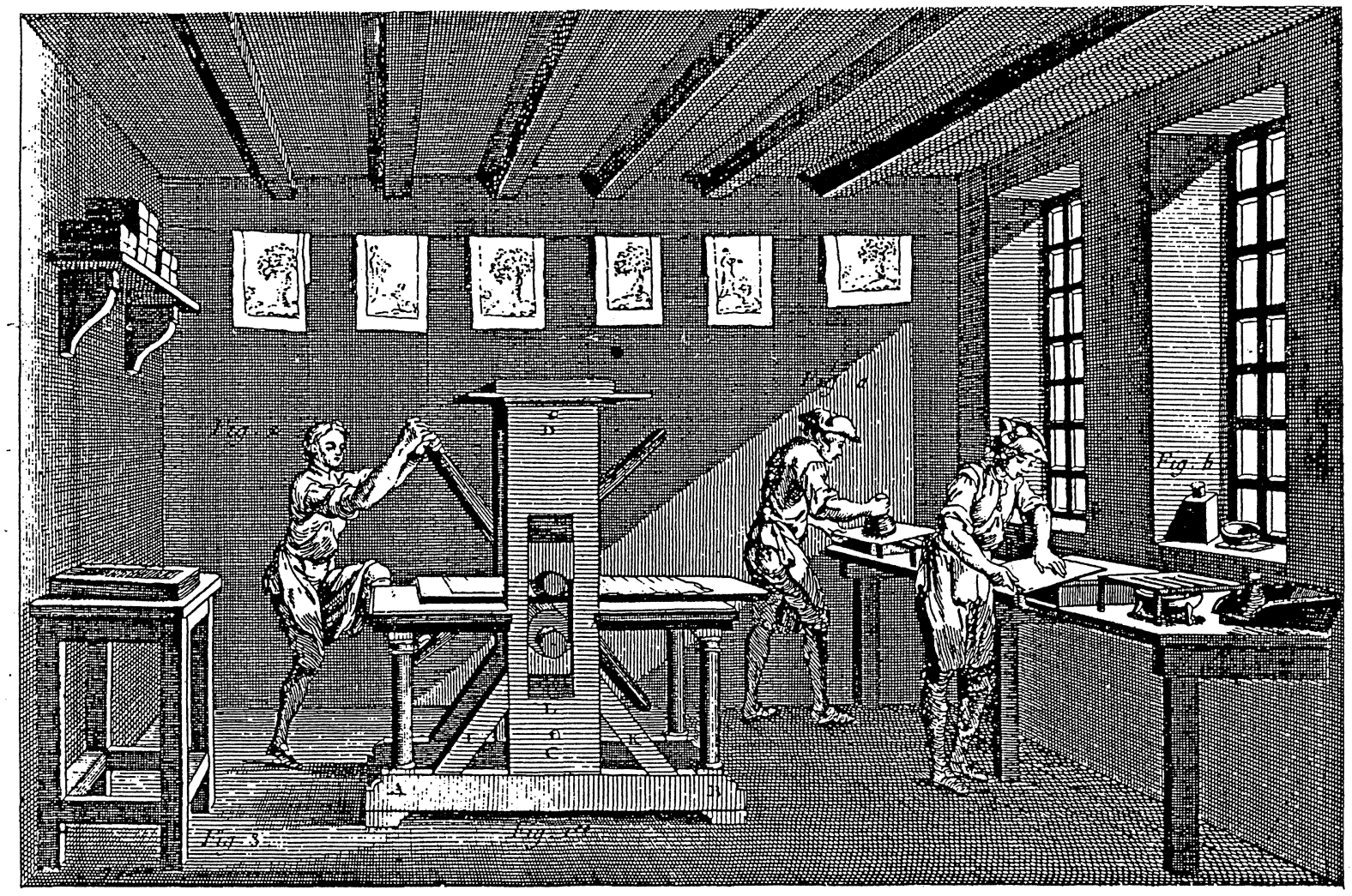

Taller francés de grabación (1751) 


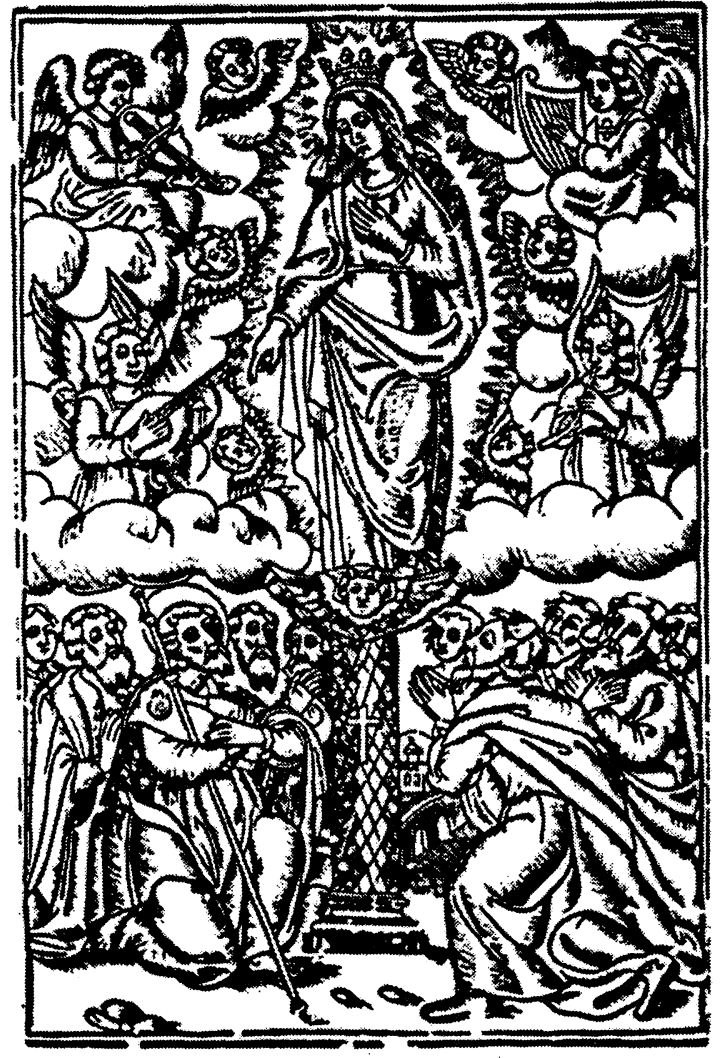

Ilustración pilarista en un pliego impreso de Luis Díez de Aux (Zaragoza, 1593; reeditado por Juan de Lanaja y Quartanet, 1631). Repárese en los ángeles músicos. 

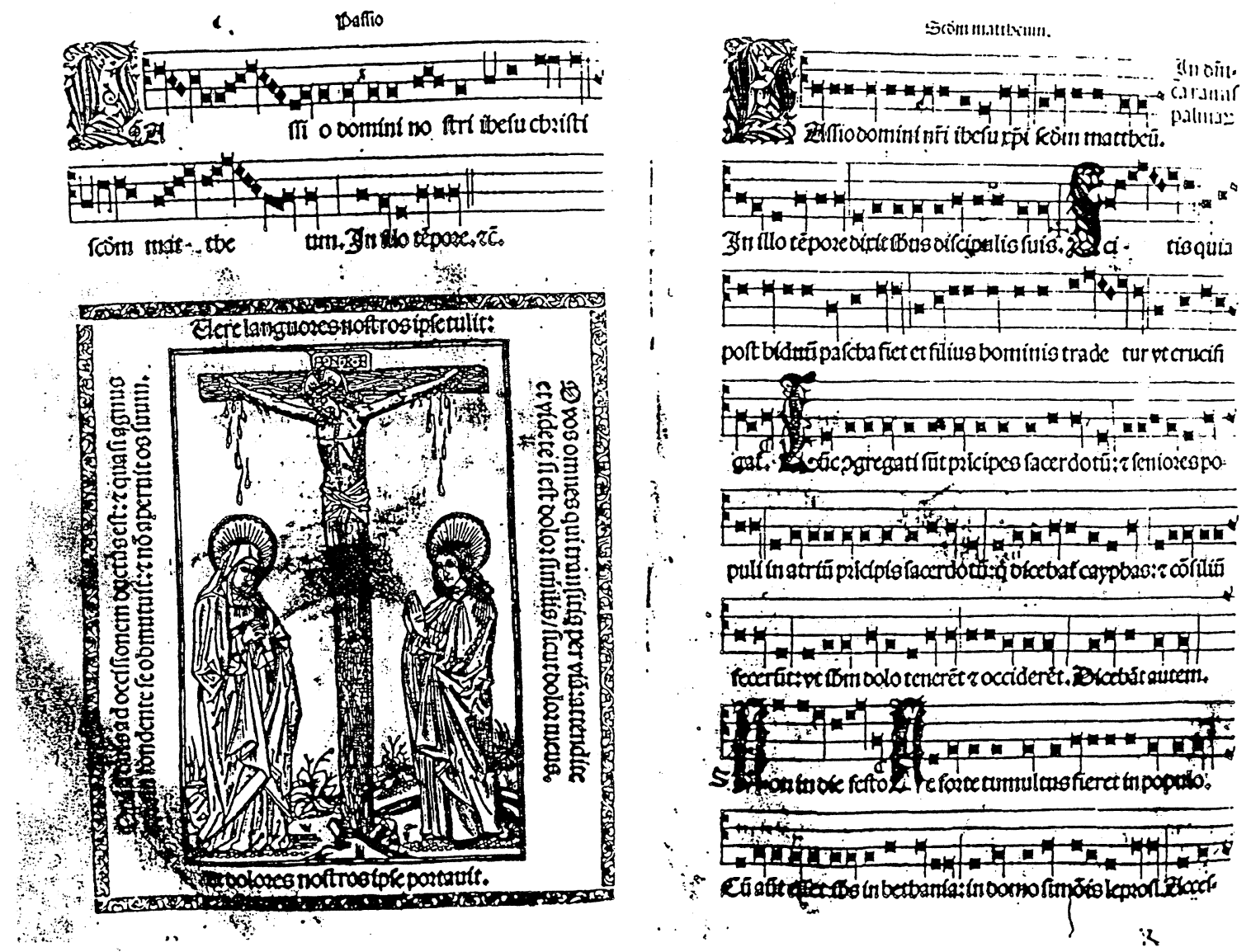

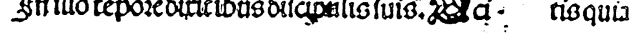

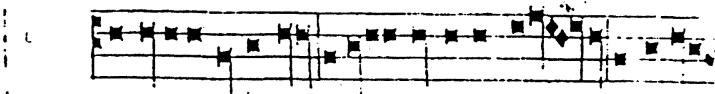

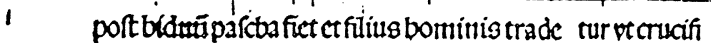

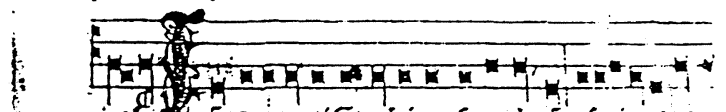

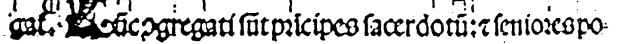

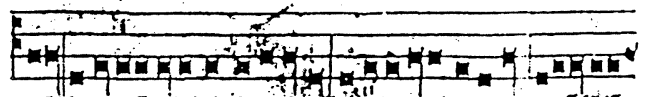

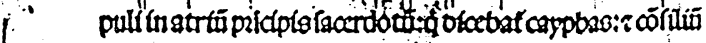
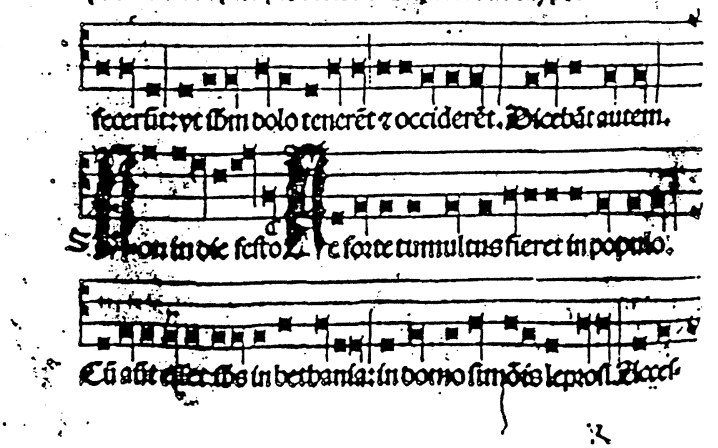

El arte tipográfico zaragozano de los siglos XV y XVI fue uno de los más destacados en la Europa de la época, gracias a alemanes e impresores extranjeros como Enrique Botel, Jorge von Holtz, Juan Plank, Leonardo Hutz, Lupo Appenteger, Pablo y Juan Hurus, o Jorge Cocci. En este sentido, los libros litúrgicos de canto, algunos de ellos todavía en vitela, pero ya muchos en papel, tuvieron una importancia verdaderamente notable. Passionarius (Zaragoza, Jorge Cocci, 1510). 

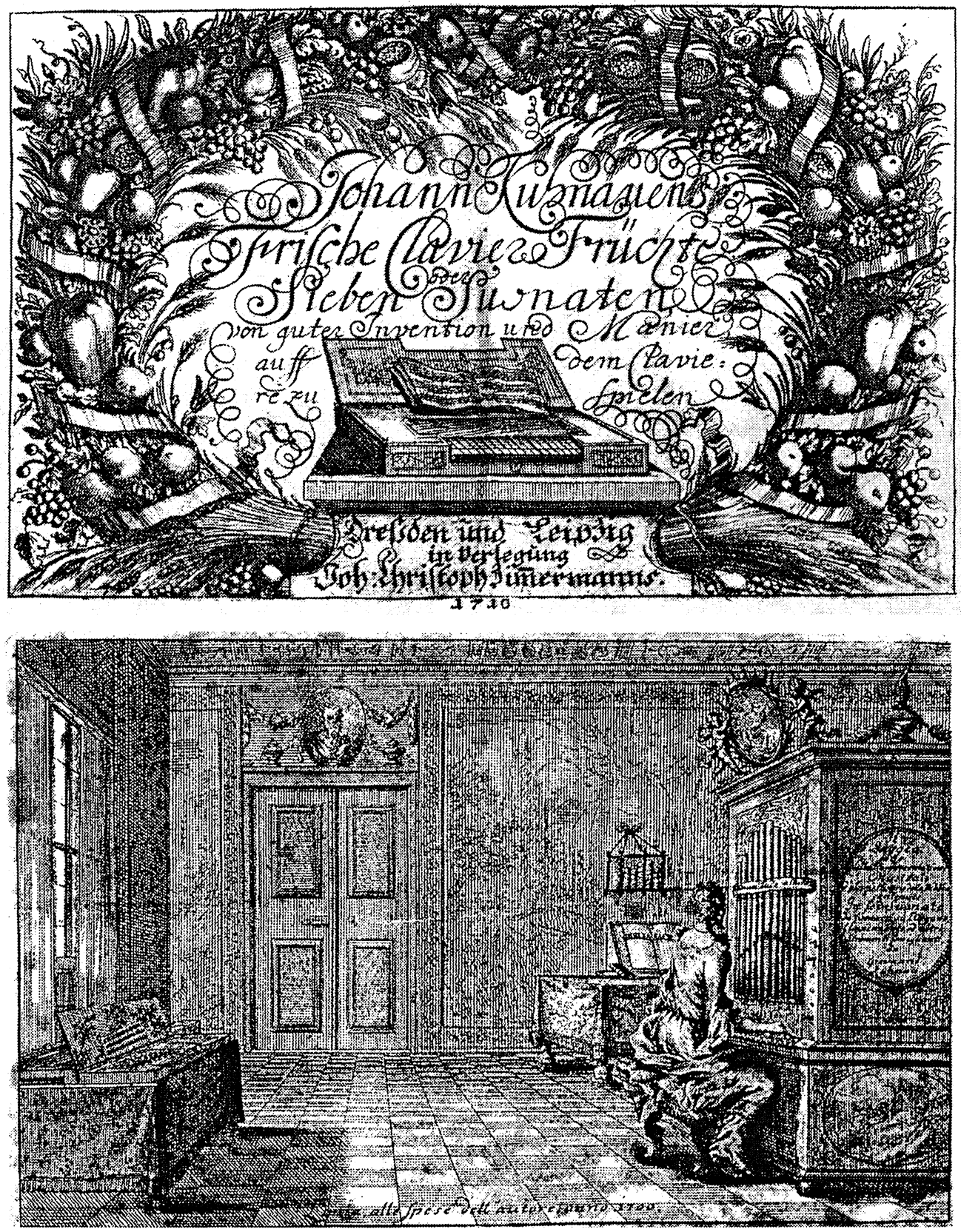

Un ejemplo de cómo, papel, libros, impresos musicales, etc., pudieron llegar a España desde lugares aparentemente remotos: en este caso, una edición del antecesor de J. S. Bach en Leipzig, que llego hasta Zaragoza. -Johann Kuhnau: Siete Sonatas de buena invención y manera para tocar al teclado (Dresde y Leipzig, Joh. Christoph Zimmerman, 1710).

[Grabado en plancha de cobre, de 1700]. (E: Zac, B-2V) 


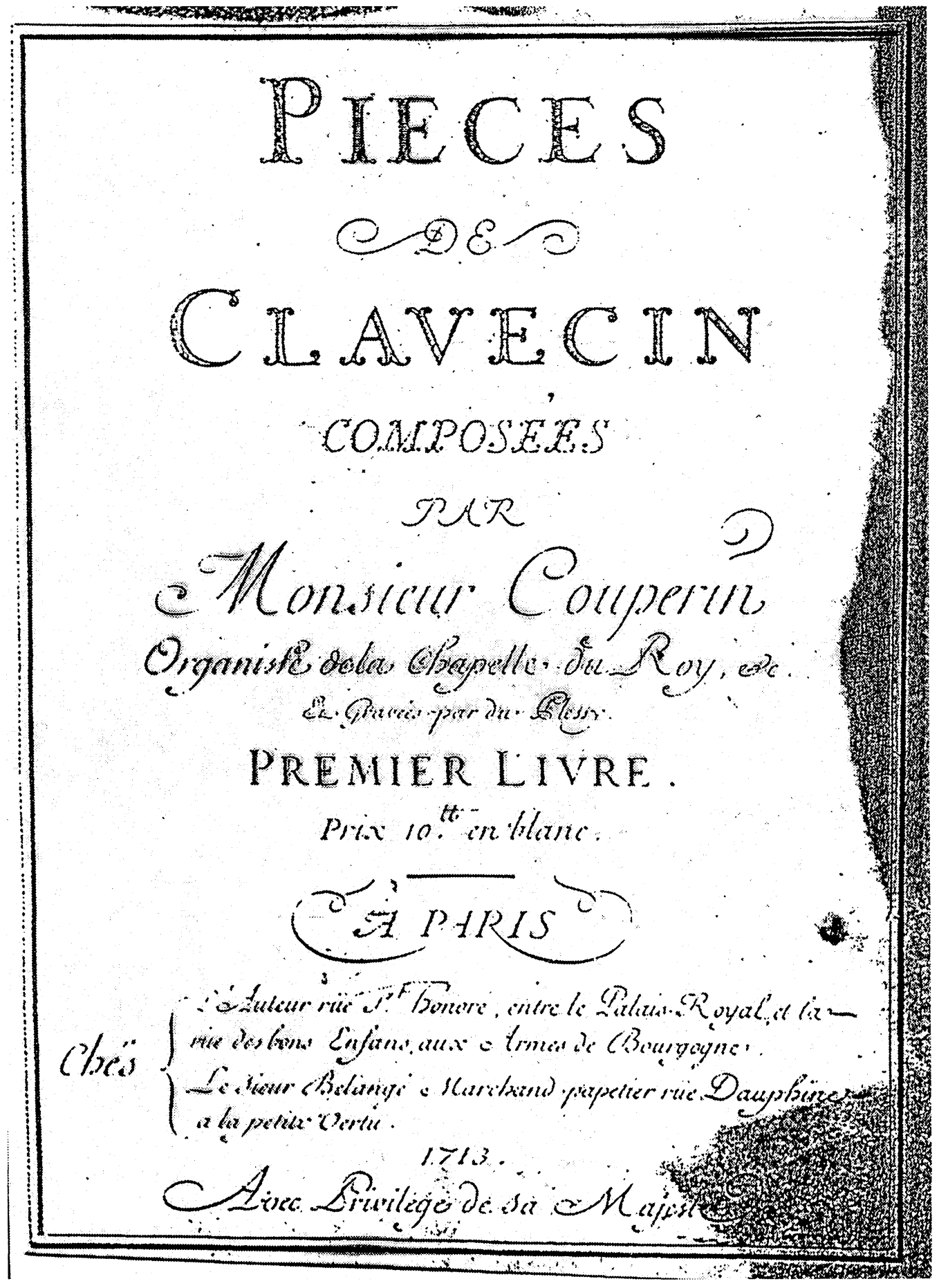

François Couperin, Pièces de clavecin (París, Du Plassy / Belangé, 1713) (E: Zac, B-2T). 


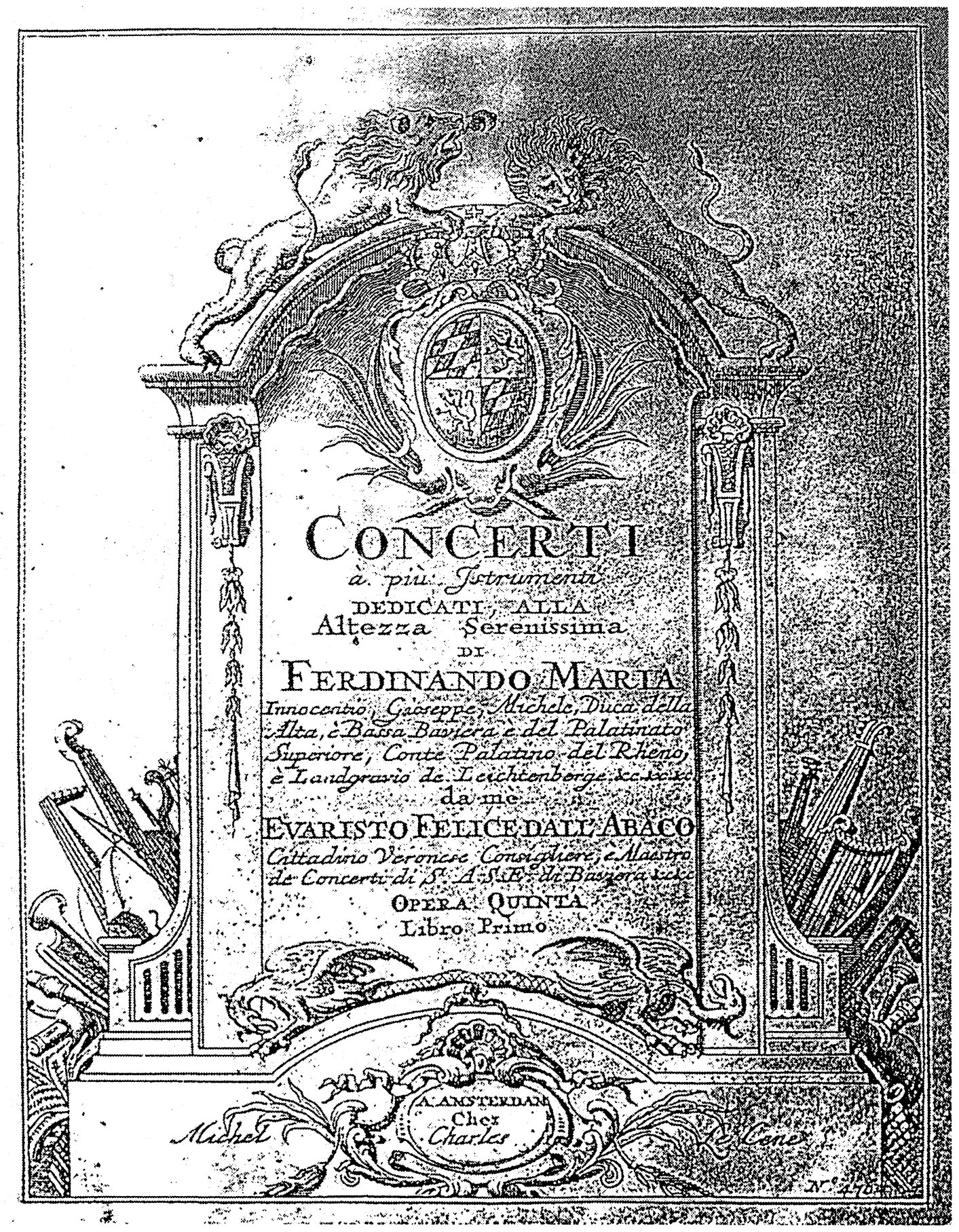

Evaristo Felice Dall' Abaco: Concerti à più Istrumenti

(Amsterdam, Le Cène, 1719c) (E: Zac, B-2R) 

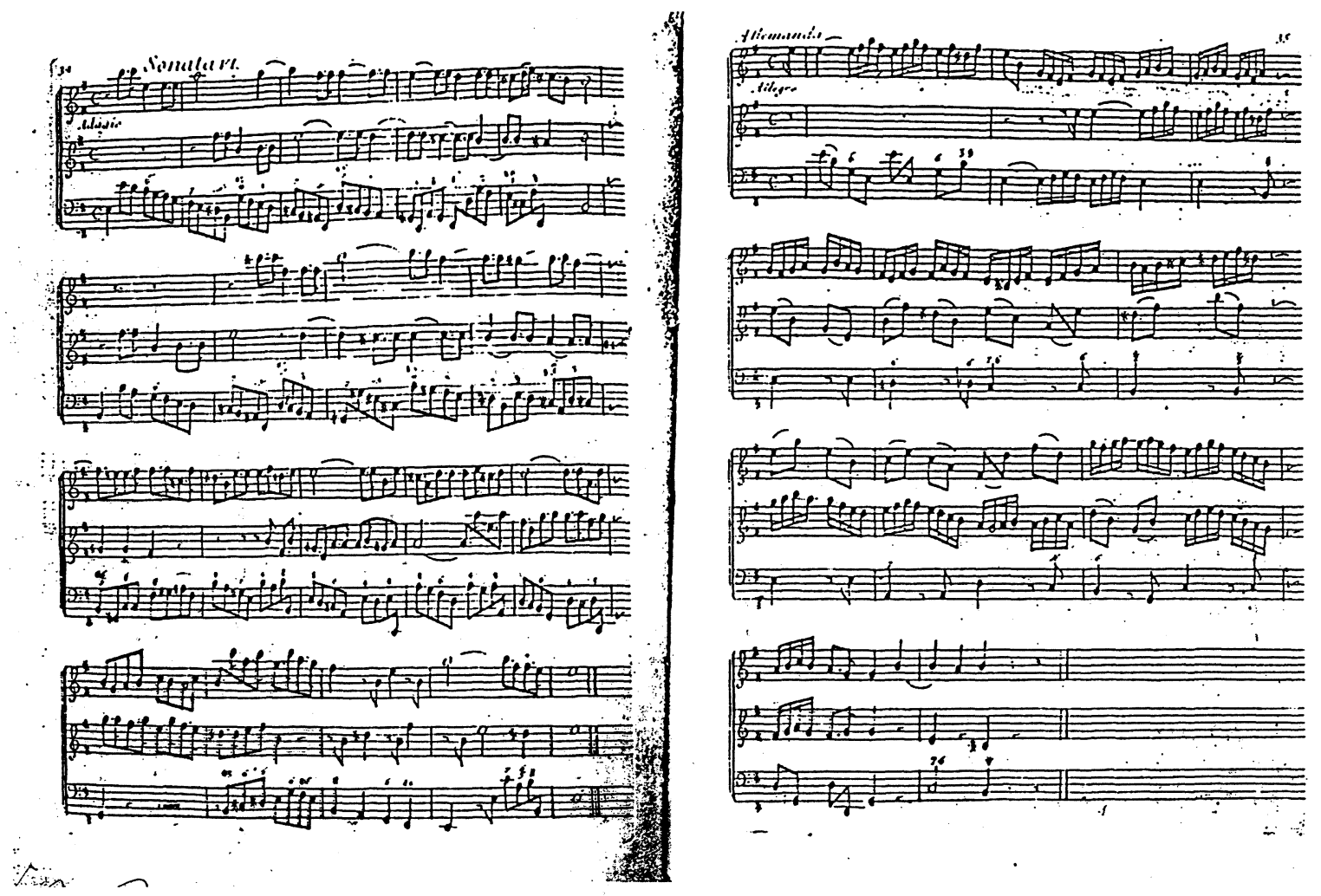

Jean François D’Andrieu Sonatas en trío (*1682- †1738) (E: Zac, B-2 Bb). 


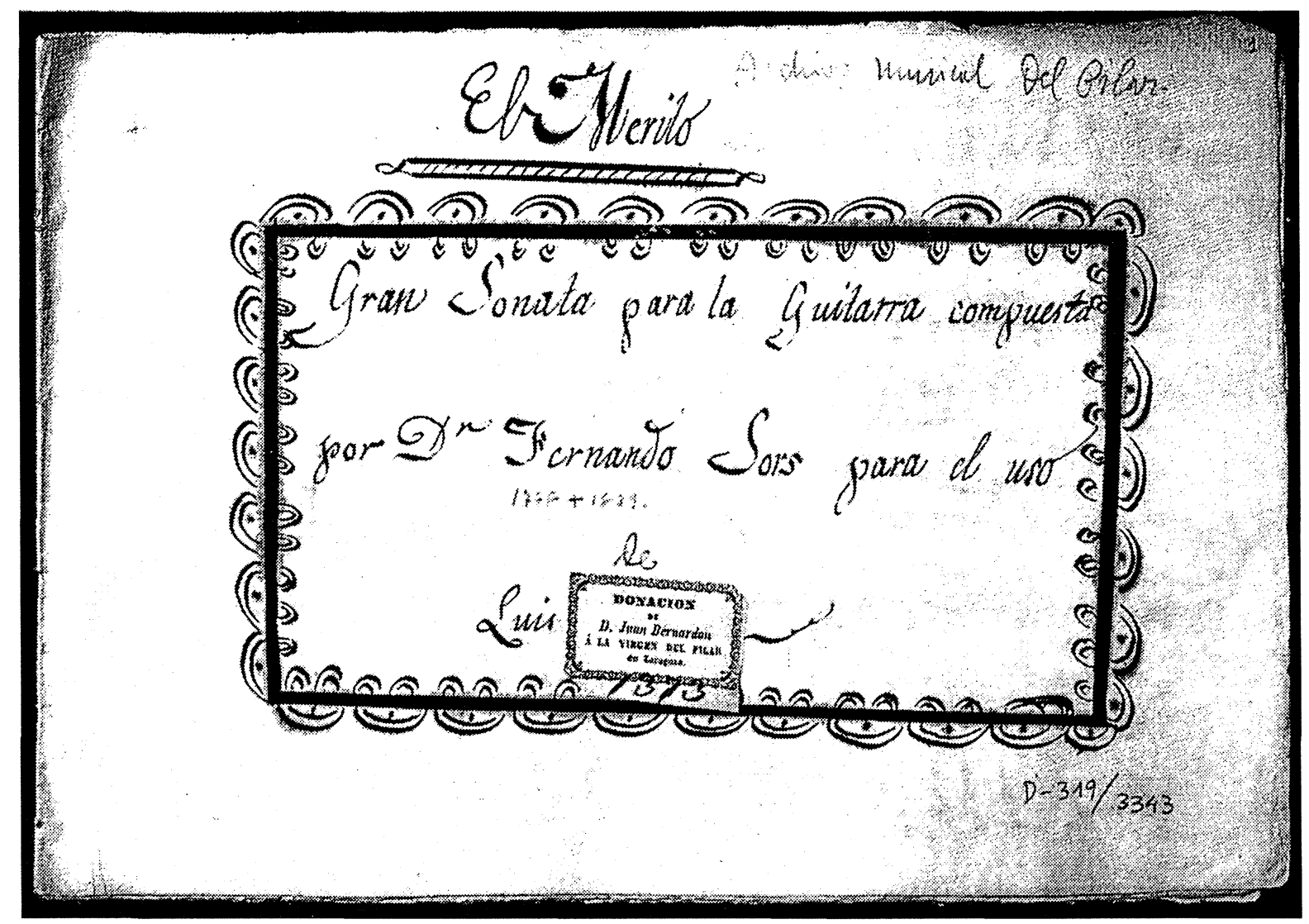

Un ejemplo de fuente musical manuscrita del primer tercio del siglo XIX, sobre soporte papel. Se trata de un cuadernillo, compuesto por hojas de cierto grosor, cercanas a un cartón fino (Archivo de Música de las Catedrales de Zaragoza) 